Prepared in cooperation with the National Park Service

Groundwater Hydrology and Chemistry of Jamestown Island, Virginia-Potential Effects of Tides, Storm Surges, and Sea-Level Rise on Archaeological, Cultural, and Ecological Resources

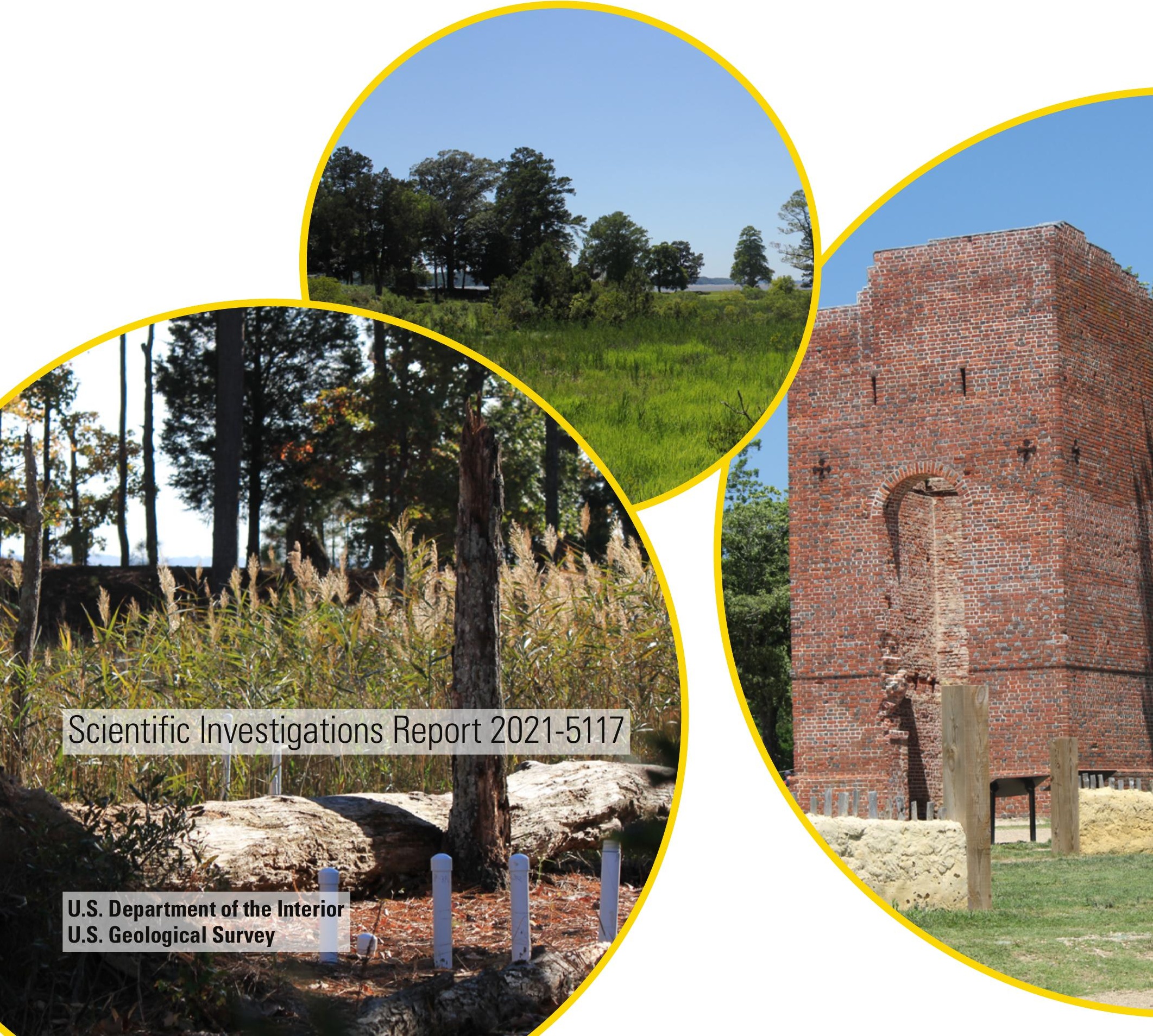


Cover. A view from the lowland uplands at Black Point across the southern marsh to the Earthworks and the James River. (Left)

The marsh encroaching into, and killing, the forest on the north side of the upper end of the Pitch and Tar Swamp as sea-level rises. (Middle)

The 17th century church tower in Olde Towne, Jamestown Island, Colonial National Historical Park, Virginia. (Right)

Photographs by U.S. Geological Survey. 


\section{Groundwater Hydrology and Chemistry of Jamestown Island, Virginia-Potential Effects of Tides, Storm Surges, and Sea-Level Rise on Archaeological, Cultural, and Ecological Resources}

By Kurt J. McCoy, Karen C. Rice, Ellyn Rickles, Dave Frederick, Jennifer Cramer, and Dorothy Geyer

Prepared in cooperation with the National Park Service

Scientific Investigations Report 2021-5117 


\section{U.S. Geological Survey, Reston, Virginia: 2021}

For more information on the USGS — the Federal source for science about the Earth, its natural and living resources, natural hazards, and the environment-visit https://www.usgs.gov or call 1-888-ASK-USGS.

For an overview of USGS information products, including maps, imagery, and publications, visit https://store.usgs.gov.

Any use of trade, firm, or product names is for descriptive purposes only and does not imply endorsement by the U.S. Government.

Although this information product, for the most part, is in the public domain, it also may contain copyrighted materials as noted in the text. Permission to reproduce copyrighted items must be secured from the copyright owner.

\section{Suggested citation:}

McCoy, K.J., Rice, K.C., Rickles, E., Frederick, D., Cramer, J., and Geyer, D., 2021, Groundwater hydrology and chemistry of Jamestown Island, Virginia-Potential effects of tides, storm surges, and sea-level rise on archaeological, cultural, and ecological resources: U.S. Geological Survey Scientific Investigations Report 2021-5117, 50 p., https://doi.org/10.3133/sir20215117.

Associated data for this publication:

Ladd, D.E., 2020, Field parameters and water levels from monitoring sites at Jamestown Island, Virginia, 2016 - 2018: U.S. Geological Survey data release, https://doi.org/10.5066/P9K7X61F.

ISSN 2328-031X (print)

ISSN 2328-0328 (online) 


\section{Acknowledgments}

The authors acknowledge the National Park Service/U.S. Geological Survey (USGS) Water-Quality Partnership for support. The authors also acknowledge USGS employees Samuel H. Caldwell, Emily H. Majcher, and David M. Rey for providing technical reviews of the report. 



\section{Contents}

Acknowledgments ……...................................................................................................................

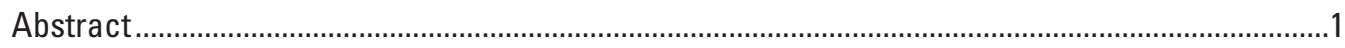

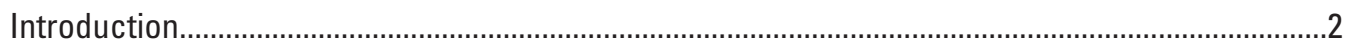

Archaeological and Cultural Resources ...............................................................................

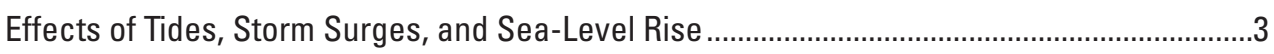

Management Strategy for Responding to the Threat..........................................................

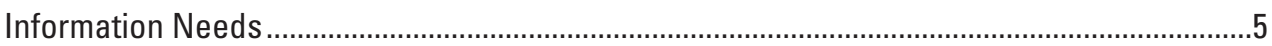

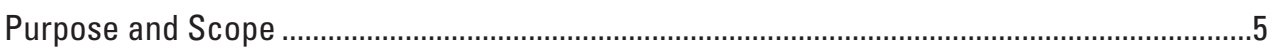

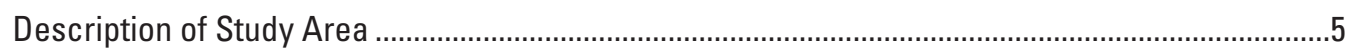

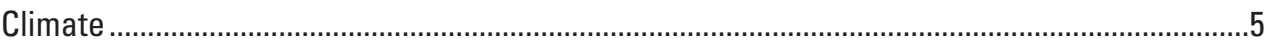

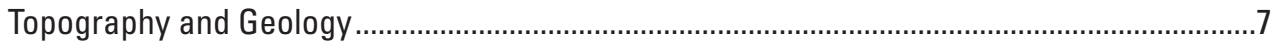

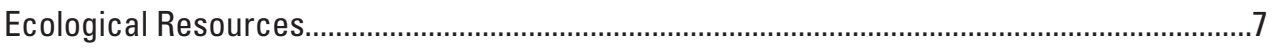

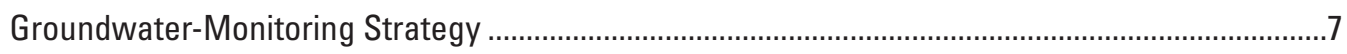

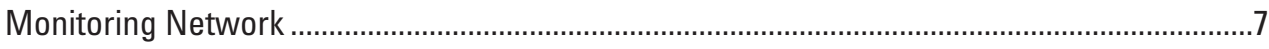

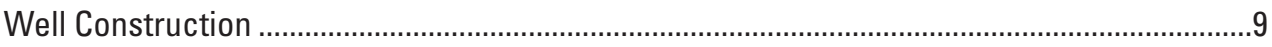

Well and Piezometer Nomenclature.................................................................................12

Groundwater-Monitoring Parameters and Frequency..........................................................13

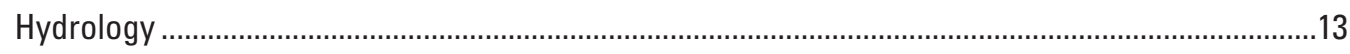

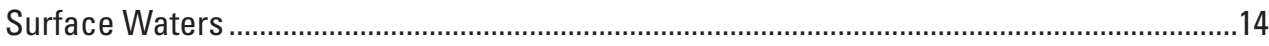

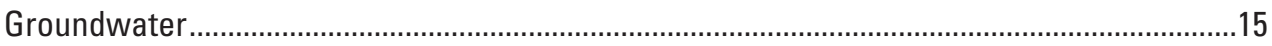

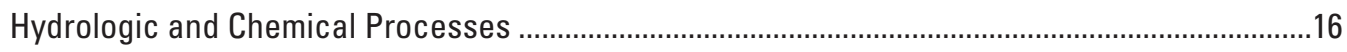

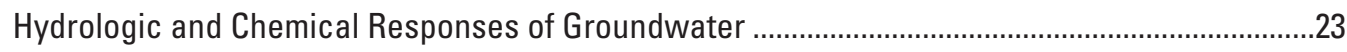

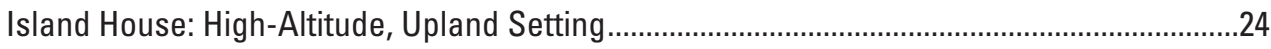

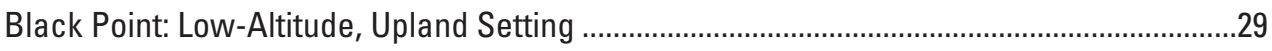

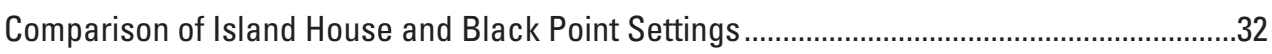

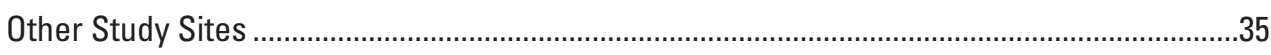

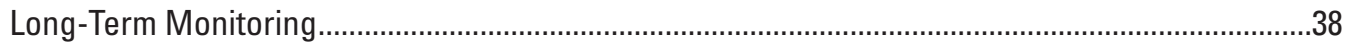

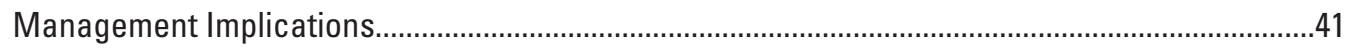

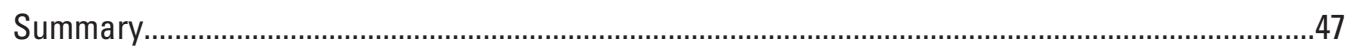

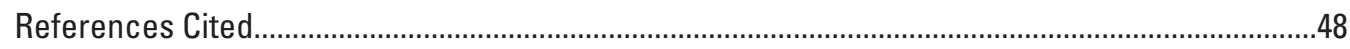

\section{Figures}

1. Map showing the location of Jamestown Island, other units within Colonial National Historical Park, tide stations, and other features near the York/James Peninsula, Virginia

2. Map showing the location of selected archaeological, cultural, and ecological resources, groundwater-monitoring sites, and other features, Jamestown Island, Colonial National Historical Park, Virginia

3. Photographs showing $A$, marsh grasses encroaching across the upland-forest floor; $B$ and $C$, dead pine trees in the expanding marsh; and $D$, stressed and dying deciduous trees on the low-altitude, upland ridge, Black Point, Jamestown Island, Colonial National Historical Park, Virginia 
4. Graph showing the average monthly air temperature, precipitation, and potential evapotranspiration for 1981 through 2010 at NOAA weather station USC00449151, Williamsburg, Virginia

5. Sections showing the depth of contacts between major sediment types, screened intervals of wells, and sand intervals at the bottoms of piezometers in transects at $A$, the Island House, $B$, Black Point, and $C$, the Earthworks, Jamestown Island, Colonial National Historical Park, Virginia

6. Schematic showing the typical construction of a piezometer and a well, Jamestown Island, Colonial National Historical Park, Virginia

7. Graphs showing the relations of $A$, dissolved solids and $B$, chloride concentrations to specific conductance to characterize the salinity of groundwater collected November 20-22, 2017, Jamestown Island, Colonial National Historical Park, Virginia

8. Graph showing the distributions of the daily highest high and lowest low tides in the James River at Jamestown Ferry Pier, Va., August 13, 2015, through October 1, 2018, Jamestown Island, Colonial National Historical Park, Virginia ..

9. Schematic showing the interconnection between sediment of differing permeability in the Surficial aquifer with the James River and the channels of smaller streams, Jamestown Island, Virginia..

10. Schematic diagrams showing $A$, the freshwater lens overlying saline water beneath a coastal island and $B$, the decreasing extent of this lens and inundation of land by rising groundwater levels as sea level rises.

11. Schematic showing the zones of changing groundwater chemistry as saline groundwater becomes anoxic when flowing through organic sediment beneath marshes and becomes reoxygenated by various processes.

12. Photographs showing $A$, the shallow depth of roots of an uprooted deciduous tree; $B$, the wide spread of the same shallow roots; and $C$, the shallow roots and the abrupt termination of a tap root with spreading smaller roots of an uprooted pine tree, Jamestown Island, Colonial National Historical Park, Virginia

13. Graph showing sinusoidal and stair-step diurnal cycles in groundwater levels, which results from daytime evapotranspiration.

14. Graphs showing discharge of the James River near Richmond, Va., from October 2016 through July 2018 as well as $A$, periodic specific conductance, and $B$, periodic dissolved oxygen of the James River at the Earthworks, Jamestown Island, Colonial National Historical Park, Virginia

15. Graph showing the specific conductance of water from the James River at the Earthworks, the marsh at the Island House, the south marsh at Black Point, the James River at Black Point, and the marsh at the Earthworks, from October 2016 through February 2018, Jamestown Island, Colonial National Historical Park, Virginia

16. Graphs showing the altitude of groundwater levels in $A$, the deepest wells and piezometers at all sites and the second deepest piezometer at site 6 , and $B$, the deepest wells and piezometers at all sites and the shallower wells and piezometers at sites 2, 3, and 6 along the transect at the Island House, Jamestown Island, Colonial National Historical Park, Virginia ....

17. Graphs showing dissolved-oxygen concentrations of water from the James River at the Earthworks and of groundwater $A$, beneath the marsh and the marsh/forest edge, and $B$, beneath the uplands at the Island House from December 2016 through August 2018, Jamestown Island, Colonial National Historical Park, Virginia 
18. Graphs showing the specific conductance of water from the James River at the Earthworks and of groundwater $A$, beneath the marsh and the marsh/forest edge on an arithmetic scale; $B$, beneath the uplands on an arithmetic scale; and $C$, beneath the uplands on a logarithmic scale at the Island House from December 2016 through August 2018, Jamestown Island, Colonial National Historical Park, Virginia .....

19. Graphs showing the $\mathrm{pH}$ of water from the James River at the Earthworks and of groundwater $A$, beneath the marsh and the marsh/forest edge; and $B$, beneath the uplands at the Island House from December 2016 through August 2018, Jamestown Island, Colonial National Historical Park, Virginia

20. Graphs showing groundwater-level altitudes in $A$, the deepest wells open to the coarse-grained sand beneath the northern marsh, the uplands, and the southern marsh; and $B$, wells open to different depths and sediment types beneath the uplands at Black Point, October 2016 to October 2018, Jamestown Island, Colonial National Historical Park, Virginia

21. Graphs showing the specific conductance of water from the James River at the Earthworks and of groundwater from wells and piezometers beneath $A$, the northern marsh and the northern marsh/forest edge, $B$, the southern marsh and the southern marsh/forest edge, and $C$, the center of the uplands at Black Point, October 2016 to October 2018, Jamestown Island, Colonial National Historical Park, Virginia ...

22. Graphs showing the $\mathrm{pH}$ of water from the James River at the Earthworks and of groundwater from wells and piezometers beneath $A$, the northern marsh and the northern marsh/forest edge, $B$, the southern marsh and the southern marsh/forest edge, and $C$, the center of the uplands at Black Point, October 2016 to October 2018, Jamestown Island, Colonial National Historical Park, Virginia

23. Graphs showing dissolved-oxygen concentrations in water from the James River at the Earthworks and of groundwater in $A$, the deepest wells open to the coarse-grained sand beneath the northern marsh, the northern marsh/forest edge, the southern marsh/forest edge, and the southern marsh; and $B$, wells open to different depths and sediment types beneath the middle of the uplands at Black Point, October 2016 to October 2018, Jamestown Island, Colonial National Historical Park, Virginia

24. Graphs showing $A$, water-level altitude, $B$, specific conductance, and $C$, $\mathrm{pH}$ of water from the James River at the Earthworks and of groundwater at Tour Road 1, October 2016 through August 2018, Jamestown Island, Colonial National Historical Park, Virginia

25. Graphs showing $A$, water-level altitude, $B$, specific conductance, and $C$, $\mathrm{pH}$ of water from the James River at the Earthworks and of groundwater at Tour Road 2, October 2016 through August 2018, Jamestown Island, Colonial National Historical Park, Virginia

26. Graphs showing the altitude of groundwater levels $A$, beneath and at the marsh/forest edge, and $B$, beneath the upland ridge at the Earthworks, October 2016 through August 2018, Jamestown Island, Colonial National Historical Park, Virginia .

27. Graphs showing the specific conductance of water from the James River and of groundwater $A$, beneath the marsh and at the marsh/forest edge, and $B$, beneath the upland ridge at the Earthworks, October 2016 through August 2018, Jamestown Island, Colonial National Historical Park, Virginia . 
28. Graphs showing the $\mathrm{pH}$ of water from the James River and of groundwater $A$, beneath and at the marsh/forest edge, and $B$, beneath the upland ridge at the Earthworks, October 2016 through August 2018, Jamestown Island, Colonial National Historical Park, Virginia

29. Maps showing the land-surface altitude and areas inundated when the water-surface altitude from high tides or storm surges reaches $A, 1.5$ feet, $B, 2.0$ feet, $C, 2.5$ feet, $D, 3.0$ feet, and $E, 5.0$ feet above North American Vertical Datum of 1988 on Jamestown Island, Colonial National Historical Park, Virginia

\section{Tables}

1. Description of wells and piezometers in the monitoring network, Jamestown Island, Colonial National Historical Park, Virginia

2. Relations of degrees of salinity to dissolved-solids concentrations and to specific conductance and chloride concentrations in groundwater samples collected November 20-22, 2017, Jamestown Island, Colonial National Historical Park, Virginia

3. Percent of days and average number of days per year that well or piezometer sites were inundated during high tide for the period August 13, 2015, through February 20, 2018, Jamestown Island, Colonial National Historical Park, Virginia 


\section{Conversion Factors}

U.S. customary units to International System of Units

\begin{tabular}{|c|c|c|}
\hline Multiply & By & To obtain \\
\hline \multicolumn{3}{|c|}{ Length } \\
\hline inch (in.) & 25.4 & millimeter $(\mathrm{mm})$ \\
\hline foot $(\mathrm{ft})$ & 0.3048 & meter $(\mathrm{m})$ \\
\hline mile (mi) & 1.609 & kilometer $(\mathrm{km})$ \\
\hline \multicolumn{3}{|c|}{ Area } \\
\hline acre & 4,047 & square meter $\left(\mathrm{m}^{2}\right)$ \\
\hline acre & 0.4047 & hectare (ha) \\
\hline acre & 0.4047 & square hectometer $\left(\mathrm{hm}^{2}\right)$ \\
\hline acre & 0.004047 & square kilometer $\left(\mathrm{km}^{2}\right)$ \\
\hline square foot $\left(\mathrm{ft}^{2}\right)$ & 0.09290 & square meter $\left(\mathrm{m}^{2}\right)$ \\
\hline square inch $\left(\mathrm{in}^{2}\right)$ & 6.452 & square centimeter $\left(\mathrm{cm}^{2}\right)$ \\
\hline square mile $\left(\mathrm{mi}^{2}\right)$ & 259.0 & hectare (ha) \\
\hline square mile $\left(\mathrm{mi}^{2}\right)$ & 2.590 & square kilometer $\left(\mathrm{km}^{2}\right)$ \\
\hline \multicolumn{3}{|c|}{ Volume } \\
\hline cubic foot $\left(\mathrm{ft}^{3}\right)$ & 0.02832 & cubic meter $\left(\mathrm{m}^{3}\right)$ \\
\hline \multicolumn{3}{|c|}{ Flow rate } \\
\hline cubic foot per second $\left(\mathrm{ft}^{3} / \mathrm{s}\right)$ & 0.02832 & cubic meter per second $\left(\mathrm{m}^{3} / \mathrm{s}\right)$ \\
\hline \multicolumn{3}{|c|}{ Specific capacity } \\
\hline $\begin{array}{l}\text { gallon per minute per foot } \\
[(\mathrm{gal} / \mathrm{min}) / \mathrm{ft})]\end{array}$ & 0.2070 & liter per second per meter $[(\mathrm{L} / \mathrm{s}) / \mathrm{m}]$ \\
\hline \multicolumn{3}{|c|}{ Hydraulic conductivity } \\
\hline foot per day $(\mathrm{ft} / \mathrm{d})$ & 0.3048 & meter per day $(\mathrm{m} / \mathrm{d})$ \\
\hline \multicolumn{3}{|c|}{ Hydraulic gradient } \\
\hline foot per mile (ft/mi) & 0.1894 & meter per kilometer $(\mathrm{m} / \mathrm{km})$ \\
\hline \multicolumn{3}{|c|}{ Transmissivity } \\
\hline foot squared per day $\left(\mathrm{ft}^{2} / \mathrm{d}\right)$ & 0.09290 & meter squared per day $\left(\mathrm{m}^{2} / \mathrm{d}\right)$ \\
\hline
\end{tabular}

Temperature in degrees Fahrenheit $\left({ }^{\circ} \mathrm{F}\right)$ may be converted to degrees Celsius $\left({ }^{\circ} \mathrm{C}\right)$ as follows:

$$
{ }^{\circ} \mathrm{C}=\left({ }^{\circ} \mathrm{F}-32\right) / 1.8 .
$$




\section{Datum}

Vertical coordinate information is referenced to the North American Vertical Datum of 1988 (NAVD 88).

Horizontal coordinate information is referenced to the North American Datum of 1983 (NAD 83).

Altitude, as used in this report, refers to distance above the vertical datum.

\section{Supplemental Information}

Specific conductance is given in microsiemens per centimeter at 25 degrees Celsius $(\mu \mathrm{S} / \mathrm{cm}$ at $\left.25^{\circ} \mathrm{C}\right)$.

Concentrations of chemical constituents in water are given in either milligrams per liter (mg/L) or micrograms per liter $(\mu \mathrm{g} / \mathrm{L})$.

$\mathrm{pH}$ is given in standard $\mathrm{pH}$ units.

\section{Abbreviations}

$\begin{array}{ll}\text { BP } & \text { Black Point } \\ \text { COLO } & \text { Colonial National Historical Park } \\ \text { ET } & \text { evapotranspiration } \\ \text { EW } & \text { Earthworks } \\ \text { IH } & \text { Island House } \\ \text { NAVD 88 } & \text { North American Vertical Datum of } 1988 \\ \text { NOAA } & \text { National Oceanic and Atmospheric Administration } \\ \text { NPS } & \text { National Park Service } \\ \text { PET } & \text { potential evapotranspiration } \\ \text { PV } & \text { Preservation Virginia } \\ \text { PVC } & \text { polyvinyl chloride } \\ \text { TR } & \text { Tour Road } \\ \text { USGS } & \text { U.S. Geological Survey }\end{array}$




\title{
Groundwater Hydrology and Chemistry of Jamestown Island, Virginia-Potential Effects of Tides, Storm Surges, and Sea-Level Rise on Archaeological, Cultural, and Ecological Resources
}

\author{
By Kurt J. McCoy', Karen C. Rice', Ellyn Rickles², Dave Frederick², Jennifer Cramer ${ }^{2}$, and Dorothy Geyer ${ }^{2}$
}

\section{Abstract}

As the site of the first permanent English settlement in North America in 1607, Jamestown Island, Colonial National Historical Park (COLO), Virginia, contains a rich archaeological record that extends from the Paleoindian period $(15,000$ to 8,000 years ago) through the 20th century. The island is located on the lower James River near the mouth of Chesapeake Bay. Jamestown Island vegetation is dominated by upland forests surrounded by tidal, freshwater-to-oligohaline marshes. Along the Virginia coast, relative sea-level rise was more than 2.5 times the global average during the 20th century. Consequently, the National Park Service (NPS) has identified COLO as one of the 25 national parks most threatened by climate change.

Surface waters across the island are hydraulically connected to the laterally continuous Surficial aquifer. The land-surface altitude of the island is low, with two-thirds of the island less than 5 feet (ft) above the North American Vertical Datum of 1988 (NAVD 88). Consequently, sea-level rise, combined with tides and storm surges, threatens the island and its resources as surface-water and groundwater levels rise, saltwater enters the Surficial aquifer, and groundwater chemistry changes. The impact of sea-level rise on the island's surface-water resources has been well studied, but groundwater effects have been largely ignored. Quantifying the effects of tides, storm surges, and sea-level rise on groundwater levels and chemistry is essential to developing an effective strategy for managing climate-induced changes. The first step in developing a response strategy includes a parkwide general risk assessment for archaeological sites on the island, so that sites can be prioritized for management actions. The U.S. Geological Survey and the NPS began a study in 2015 to develop a long-term groundwater-monitoring program to evaluate this risk and to develop an updated management strategy.

${ }^{1}$ U.S. Geological Survey.

${ }^{2}$ National Park Service.
The groundwater-monitoring program consists of 45 wells and piezometers in two individual clusters and three transects across the island in different hydrologic and chemical settings. Samples for water quality were collected from the wells and piezometers from October 2015 through September 2018 at variable time intervals. Results of the monitoring identified disparate hydrologic and chemical responses to saltwater intrusion across the island. Specific conductance (an indicator of salinity) of groundwater beneath several marshes responded differently to changes in James River salinity. Groundwater response to changes in James River specific conductance appeared to be controlled by land-surface altitude and slope, differences in lateral and vertical sediment characteristics, distance from surface waters, and the degree of surface water/ groundwater connectivity between channels and the aquifer.

Groundwater chemistry data from monitoring wells at Black Point, a low-altitude, upland setting, are in contrast with conditions observed in Island House observation wells, a high-altitude, upland setting. Specific conductance (less than 200 microsiemens per centimeter $[\mu \mathrm{S} / \mathrm{cm}]$ ) and $\mathrm{pH}$ (greater than 5.0) of groundwater beneath much of the uplands that characterize the Island House observation wells are typical of groundwater in noncarbonate sedimentary aquifers recharged by precipitation. At Black Point, specific conductance ranged from 2,490 to $15,200 \mu \mathrm{S} / \mathrm{cm}$, and $\mathrm{pH}$ ranged from 3.1 to 6.6 standard units. At the Black Point observation wells, the most saline and dense water was at the water table rather than deeper in the aquifer, causing a density inversion that persisted throughout the study. The density inversion likely resulted from differences in permeability between the shallow clay and fine-grained sands and the deeper coarse-grained sand and gravel. Groundwater with the lowest $\mathrm{pH}$ was at the water table. As saline groundwater flows through organic sediment beneath the marshes, bacterial biodegradation of organic matter creates anoxic conditions. Continued biodegradation concomitantly reduces iron-oxide minerals in the sediment and sulfate in saline water. When oxygen is reintroduced into groundwater, iron and sulfur can reoxidize to form sulfuric acid, locally lowering the $\mathrm{pH}$ of the water. 
This report describes the groundwater monitoring network design, rationale for site selection, monitoring approach, and results of monitoring from October 2015 through September 2018. Maps of inundation at selected water-level altitudes are included to identify the risk to archaeological, cultural, and ecological resources. The monitoring results of the hydrology and chemistry data are interpreted, and the different hydrologic and chemical settings are described. The implications of the study results for management decisions are presented, and suggestions for improving the monitoring network are included.

\section{Introduction}

Colonial National Historical Park (COLO) has preserved and protected the archaeological, cultural, and ecological resources on the York/James Peninsula in southeastern Virginia since legislation established the park in 1930 (fig. 1). As part of an area known as the Historic Triangle, COLO consists of several units that include Yorktown Battlefield on the York

River along the north shore of the peninsula, Jamestown Island on the James River along the south shore of the peninsula, and the 23-mile (mi.) long Colonial Parkway, which connects these units. Jamestown Island was initially known as the site of the first permanent English settlement in North America in 1607, although recent studies have identified a more extensive historical significance of the island. Since 1893, Preservation Virginia (PV), a nonprofit organization dedicated to preserving the cultural, architectural, and historical heritage of Virginia, has owned 22.5 acres in the northwest corner of the 1,500-acre island; the National Park Service (NPS) owns the remainder of the island (fig. 2). Through joint ownership, the NPS and PV cooperatively manage the island.

Saunders and others (2009) evaluated 391 parks in the National Park system for risk to climate change; COLO is in the top 25 parks with the greatest risk. Risks from climateinduced changes at Jamestown Island primarily stem from its low land-surface altitude and its location between the York River and James River estuaries near the mouth of Chesapeake Bay and the Atlantic Ocean (fig. 1). The threat to COLO and its resources primarily is from the combined effects of tides, storm surges, and sea-level rise.

Global warming is causing global sea-level rise by the melting of land-based ice and the thermal expansion of seawater (Rahmstorf, 2010). During the 20th century, sea-level rise averaged 1.51 feet (ft) per century at the National Oceanic and Atmospheric Administration (NOAA) tide station 8638610 (Sewells Point; fig. 1) at the mouth of the James River (Ezer and Atkinson, 2015). This rate is more than 2.5 times the 0.57 $\mathrm{ft}$ per century global average (Ezer and Atkinson, 2015). At Sewells Point, rates averaged $1.17 \mathrm{ft}$ per century from 1953 to 1983 but have increased to $1.92 \mathrm{ft}$ per century from 1983 to 2013 (Ezer and Atkinson, 2015).

Higher rates of sea-level rise on the Virginia coast result from the combined effects of global, regional, and local factors that cause sea level to rise and (or) the land surface to subside (Eggleston and Pope, 2013; Ezer and Atkinson, 2015). Changes in the flow of the Gulf Stream can cause additional sea-level rise along the East Coast (Ezer and Atkinson, 2015). Simultaneously, the land surface is subsiding owing to the combined effects of glacial isostatic adjustment and regional groundwater withdrawals. Large groundwater withdrawals from deep unconsolidated aquifers overlying bedrock in southeastern Virginia results in regional subsidence by the compaction of fine-grained sediments (Eggleston and Pope, 2013). From 1940 to 1971, subsidence averaged about 0.83 $\mathrm{ft}$ per century at Jamestown Island (Holdahl and Morrison, 1974), with more than half of the subsidence being attributed to the effects of continued groundwater pumping (Eggleston and Pope, 2013). Uncertainties in future water demand and groundwater withdrawal rates, combined with uncertainty in the rates of land-surface subsidence and sea-level rise, make climate impacts on Jamestown Island difficult to predict.

Waters around Jamestown Island experience semidiurnal tides, frequently inundating low-lying areas during high tides. Additionally, periodic coastal storm surges can exacerbate tidal events. Sea-level rise, combined with tides and storm surges, pose an imminent threat to archaeological, cultural, and ecological resources and infrastructure of Jamestown Island.

\section{Archaeological and Cultural Resources}

Archaeological studies of the first permanent English settlement on the island uncovered artifacts that reveal a rich record spanning the time of human presence in eastern North America from the Paleoindian period (15,000 to 8,000 years ago; Egloff and Woodward, 2006) through the 20th century (fig. 2). Most artifacts, however, remain buried beneath these sites, leaving additional historical information that has yet to be revealed. Unearthing and interpreting these artifacts are key to identifying an extensive, detailed history of our Nation and earlier societies. A comprehensive archaeological survey from 1992 to 1997 evaluated approximately the upper 0.5 meter of soil in a gridded pattern across most of the island, excluding James Fort, the adjacent town, and New Towne (Blanton and others, 2000). The survey identified 58 archaeological sites concentrated on upland ridges (fig. 2). The report noted, however, "There is essentially no part of the island that does not contain archaeological resources, which includes the island's extensive wetlands." When considering all historical areas, archaeological sites cover approximately 80 percent of the island (National Park Service, 2001).

In addition to the Paleoindian period, sites include artifacts from the Archaic period (10,000 to 3,000 years ago; Egloff and Woodward, 2006) through the post-contact period. Post-contact sites include the fort, plantations, homesteads, Civil-War fortifications, and Civilian Conservation Corps facilities. Consequently, many sites contain artifacts from multiple periods. 


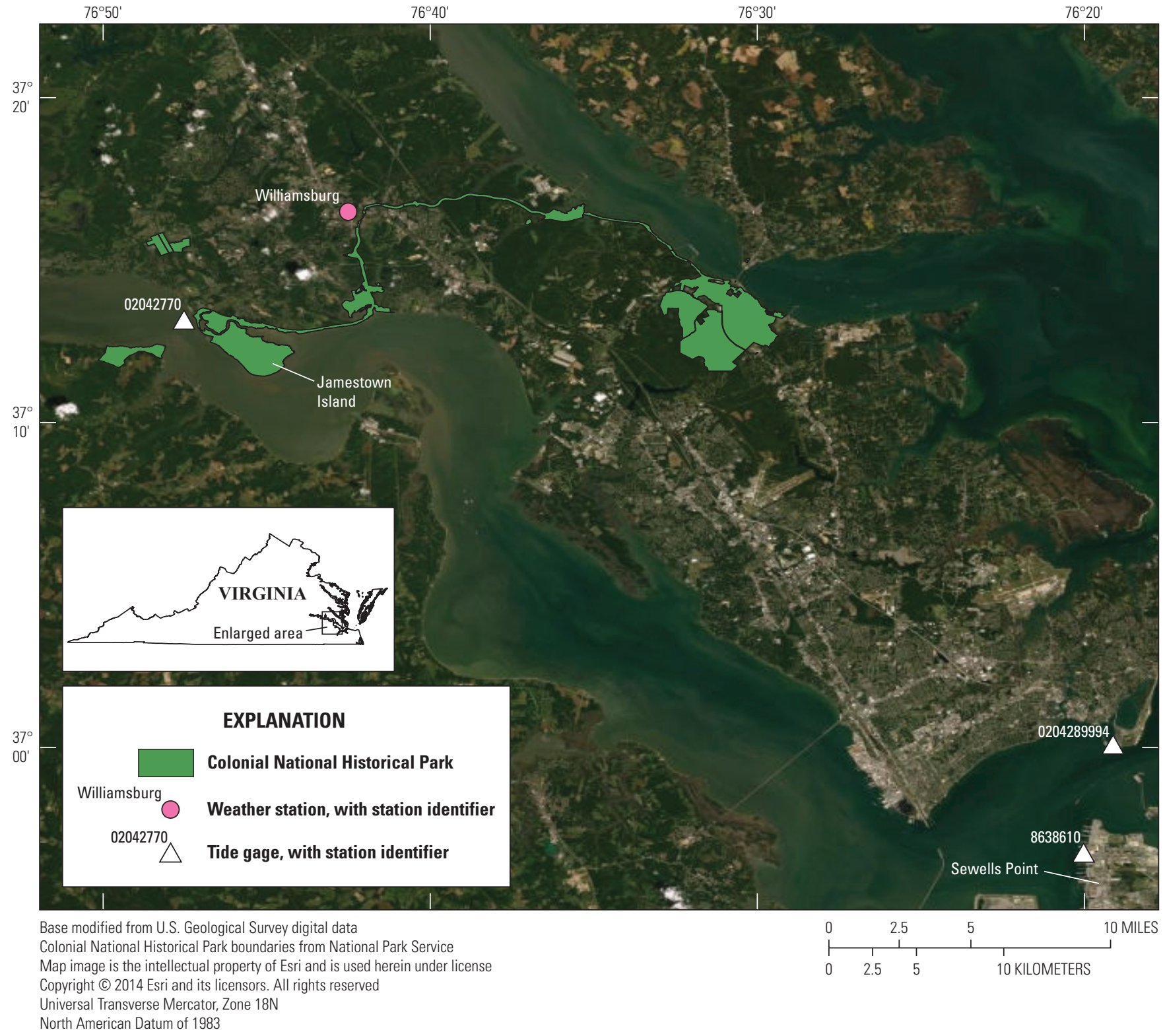

Figure 1. Map showing the location of Jamestown Island, other units within Colonial National Historical Park, tide stations, and other features near the York/James Peninsula, Virginia.

\section{Effects of Tides, Storm Surges, and Sea-Level Rise}

The effects of tides, storm surges, and sea-level rise are evident across the island, and have irreversibly damaged or destroyed parts of existing archeological sites. The archaeological record of many sites is imminently threatened by expanding marshes, inundation and saturation of formerly dry land, and shoreline erosion, with 31 of the 58 sites considered to be severely threatened (Blanton and others, 2000; Lewis, 2014; Colonial National Historical Park, written commun., March 28, 2018). As both surface and subsurface processes can damage or destroy sites, interpretation of these sites in the larger archaeological context of the island and knowledge of their importance to the history of our Nation and previous societies is reduced or lost.

Ecological damage also has been observed across the island. On upland ridges south of Passmore Creek (fig. 2), mature loblolly pine trees, which have bald-eagle nests, have been dying, thereby reducing this habitat. Additionally, pine and mixed-hardwood trees appear stressed and may die as adjacent marshes advance into low-altitude, upland forests at Black Point on the east end of the island (fig. $3 \mathrm{~A}$ ). Evidence of this vegetative stress is indicated by the locations of standing, dead pine trees (fig. $3 B$ and $3 C$ ), where the marsh appears to have encroached at least $40 \mathrm{ft}$ into the former forest, as identified by the marsh/forest edge on land-cover maps from 


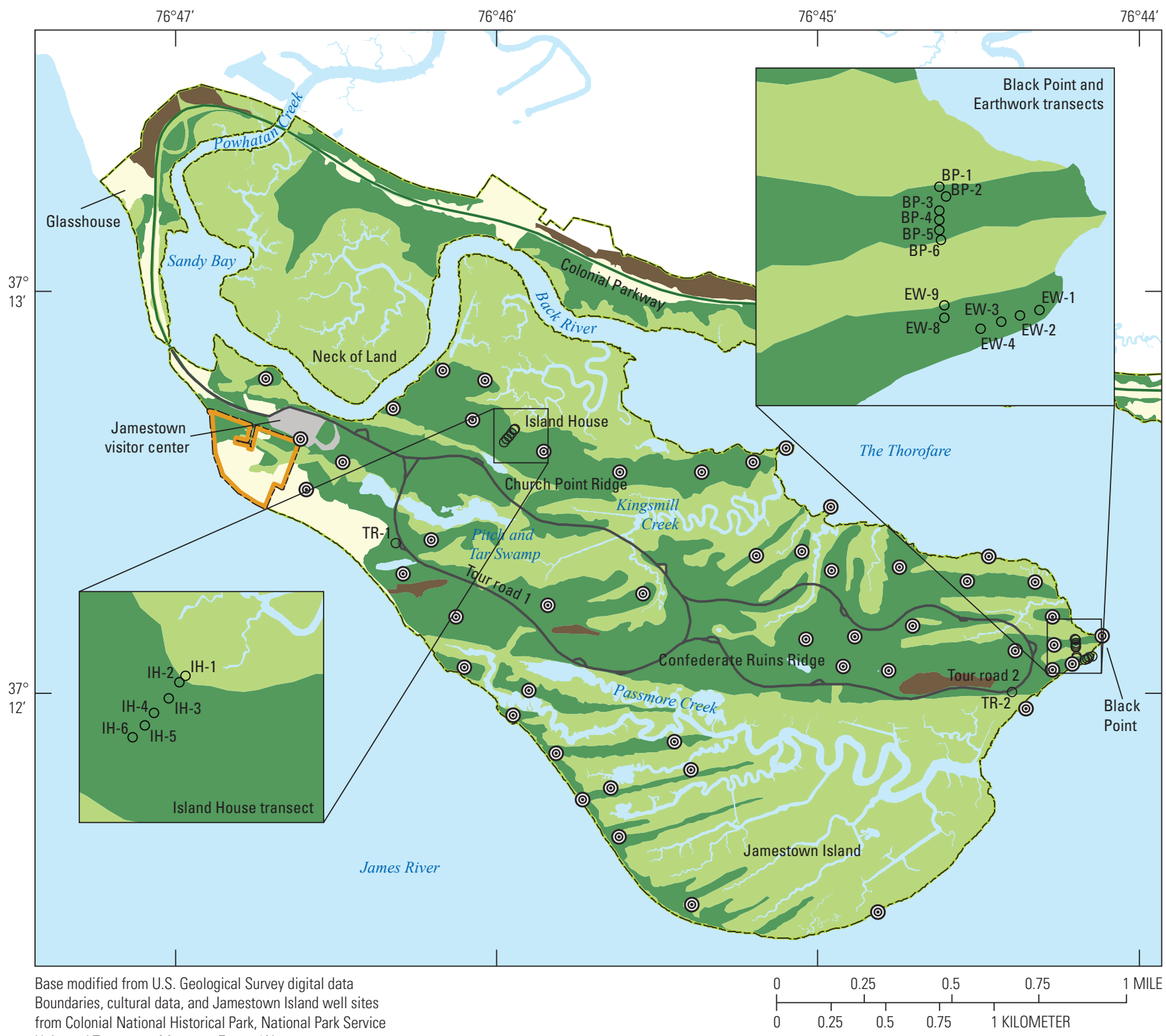

from Colonial National Historical Park, National Park Service

Universal Transverse Mercator, Zone 18N

North American Datum of 1983

\section{EXPLANATION}

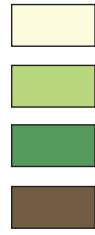

Cultural land use

Wetland

Upland-Woodland

Successional distribution
-- Preservation Virginia boundary

-_- Colonial National Historical Park boundary

(-) Archaeological site

$O^{\mathrm{IH}-1}$ Well site/cluster and number

Figure 2. Map showing the location of selected archaeological, cultural, and ecological resources, groundwater-monitoring sites, and other features, Jamestown Island, Colonial National Historical Park, Virginia. 
2008 (fig. 2). In the remaining forest, mixed-hardwood trees have visual indications of vegetative stress and are disparately dying (fig. $3 D$ ), although the pine trees in these areas appear healthy.

\section{Management Strategy for Responding to the Threat}

In 2016, COLO started developing a climate-adaption strategy, based on Ricci and others (2019), to respond to the imminent threat to the archaeological, cultural, and ecological resources and park infrastructure from tides, storm surges, sea-level rise, and groundwater chemistry. Beginning with a parkwide climate-change vulnerability assessment, integrated across natural resources, cultural resources, and facilities, the needs for further resource and site-specific adaptation planning were identified (Ricci and others, 2019). Based on vulnerabilities to archeological resources identified in the assessment, and previous archeological surveys and monitoring (Blanton and others, 2000), the need to prioritize sites based on a combination of vulnerability and significance was identified. COLO is in the process of gathering additional data to develop site-specific adaptation plans for the sites with high significance and high vulnerability, or insufficient information to assess significance. Through increased knowledge gained from this study, park management can develop a response strategy able adapt to unanticipated changes over time.

The risk to a specific archaeological or cultural site is assessed by numerically rating the historical significance and the vulnerability to tides, storm surges, and sea-level rise. Historical significance is based on multiple factors considered important by archaeologists and other knowledgeable NPS staff, including eligibility for listing on the National Register of Historic Places. Vulnerability consists of the sensitivity of artifact materials to the hydrologic and chemical effects of tides, storm surges, and sea-level rise and the anticipated exposure of these materials over the implementation period. Sensitivity depends on the types of materials contained in artifacts known to be present at the site.

Exposure of the 58 recognized sites to the effects of tides, storm surges, and sea-level rise from both surface water and groundwater largely depends on land-surface altitude. The average altitude of each of the sites ranges from -0.16 to 9.85 $\mathrm{ft}$ above the North American Vertical Datum of 1988 (NAVD 88 ), with a median of $4.45 \mathrm{ft}$ above NAVD 88 . The average altitude of 35 sites is less than $5.16 \mathrm{ft}$ above NAVD 88, which is equal to the highest tide at the Jamestown Ferry Pier tide station (U.S. Geological Survey [USGS] station 02042700) since operation began in August 2015. This tide resulted from a storm surge on October 4, 2015. Based on the maximum altitudes of these sites, 12 of the 58 sites were completely inundated by this surge. Based on minimum altitude, all or part of 57 sites were inundated by this surge.

Ratings for individual factors that incorporate both historical significance and vulnerability are weighted based on their relative importance. Weighted ratings were aggregated to provide a final rating for site prioritization, to identify and develop options for Adaptation and Resiliency Action Plans for each site, and to implement those plans. Preliminary results from this study were used, in part, in the development of the management strategy. Results published in this study, followup research, and continued long-term monitoring will be critical to the continuing effort to fully characterize the threats to the artifacts.

\section{Information Needs}

Existing knowledge of groundwater hydrology and chemistry of Jamestown Island was insufficient for a robust risk assessment. The development and implementation of an effective management strategy required additional groundwater data. In 2015, the USGS, in cooperation with the NPS, began a study of groundwater hydrology and chemistry to meet these needs with funding from the USGS/NPS Water-Quality Partnership. The study partly addressed the information needs with the installation of several transects of groundwater monitoring wells across the island. Results of continued groundwater monitoring will provide the information needed for more robust risk assessments and the development of a general park-management strategy, a site-specific risk assessment, an Adaptation and Resiliency Action Plan, and the identification of additional data and research needs.

\section{Purpose and Scope}

This report describes the groundwater monitoring network design, rationale for site selection, monitoring approach, and results of monitoring from October 2015 through September 2018. The monitoring results of the hydrology and chemistry data are interpreted, and the different hydrologic and chemical settings are described. The implications of the study results for management decisions are presented, and suggestions for improving the monitoring network are included.

\section{Description of Study Area}

Jamestown Island is on the lower James River in the Atlantic Coastal Plain of southeastern Virginia near the mouth of Chesapeake Bay and the Atlantic Ocean (fig. 1). The island is on the outside of a large bend in the James River at its confluence with Powhatan Creek and is bounded by tidal surface waters (fig. 2).

\section{Climate}

Jamestown Island has a temperate to subtropical climate (Trewartha and Horn, 1980) characterized by hot, humid summers and cool, low-humidity winters. The mean annual 

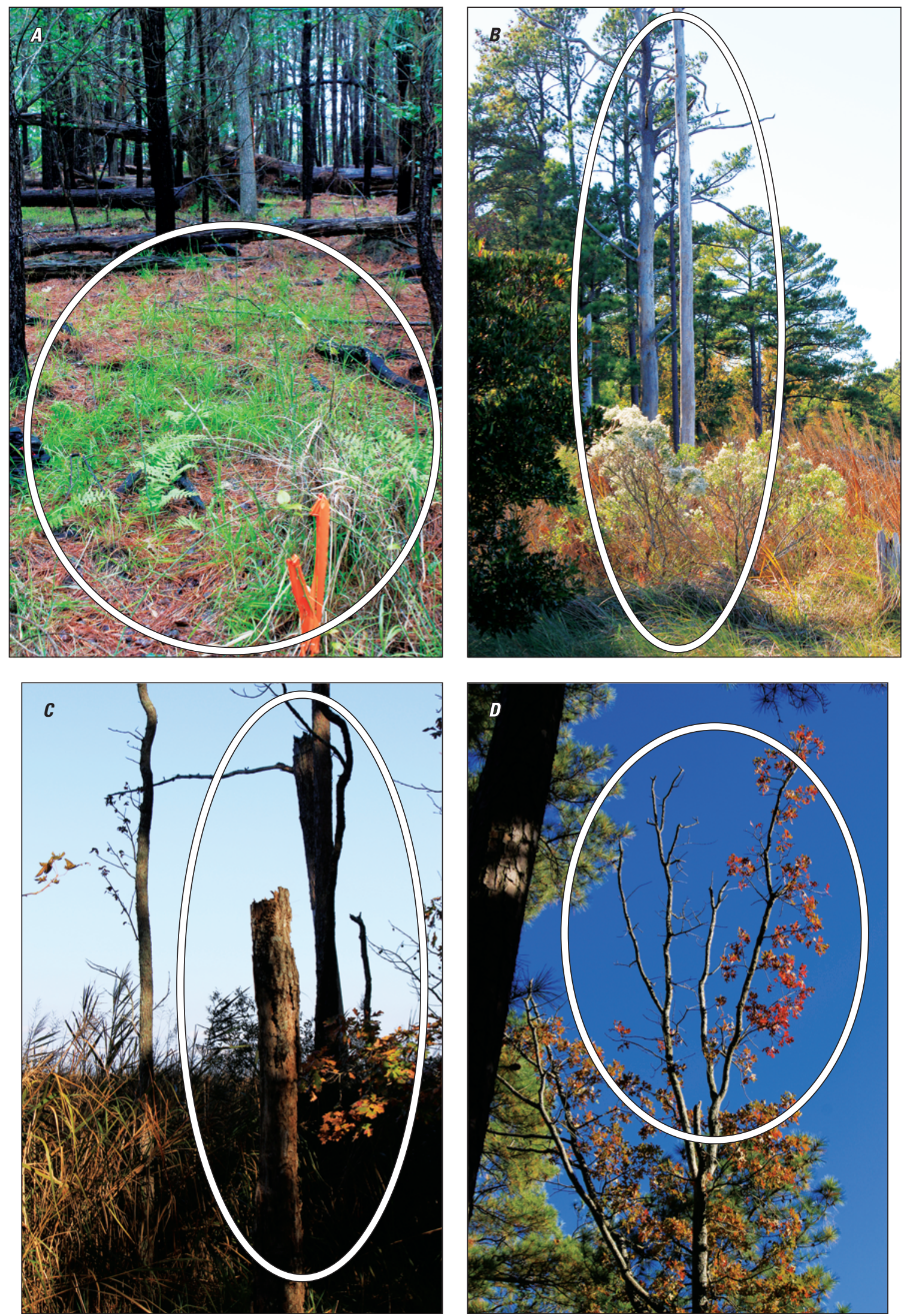

Figure 3. Photographs showing $A$, marsh grasses encroaching across the upland-forest floor; $B$ and $C$, dead pine trees in the expanding marsh; and $D$, stressed and dying deciduous trees on the low-altitude, upland ridge, Black Point, Jamestown Island, Colonial National Historical Park, Virginia. 
air temperature from 1981 to 2010 averaged 58.7 degrees Fahrenheit $\left({ }^{\circ} \mathrm{F}\right)$ at the NOAA City of Williamsburg station (Station USC00449151), north of the island (fig. 1; National Oceanic and Atmospheric Administration, 2018). The average monthly air temperature ranged from $38.5^{\circ} \mathrm{F}$ in January to $78.0^{\circ} \mathrm{F}$ in July (fig. 4). Average monthly precipitation ranged from 3.20 inches (in.) in February to 5.47 in. in July and totaled $48.31 \mathrm{in}$. annually. Although the average monthly precipitation follows this general pattern, the pattern in any single year can differ appreciably. Potential evapotranspiration (PET) averages 32.09 in. annually, two-thirds of the annual precipitation (University of Virginia, 2000). Average monthly PET follows a seasonal pattern, increasing from $0.20 \mathrm{in}$. in January to $6.14 \mathrm{in}$. in July before decreasing again into the fall season (fig. 4). The average monthly PET exceeds the average monthly precipitation in June, July, and August, despite July and August being the two months with the highest average monthly precipitation.

In general, winter precipitation accompanies frontal systems, whereas summer precipitation results from afternoon thunderstorms caused by daytime heating. Intensive low-pressure systems called nor'easters form off the coast and move to the northeast, bringing large winter precipitation events accompanied by strong winds. Low-pressure systems that can strengthen into tropical depressions, tropical storms, and hurricanes can bring heavy precipitation and strong winds from June through November. Both nor'easters and tropical systems can cause storm surges that inundate large parts of the island and cause appreciable damage.

\section{Topography and Geology}

Jamestown Island has a low-altitude, ridge and swale topography (Johnson, 2007). About 90 and 66 percent of Jamestown Island is less than $10 \mathrm{ft}$ and $5 \mathrm{ft}$ above NAVD 88, respectively (Cramer and others, 2019). Low, flat marshes, most at an altitude less than $3 \mathrm{ft}$ above NAVD 88, form most of the swales that separate and surround the ridges. From the north, the two main ridges are Church Point and Confederate Ruins, each having a general east-west orientation (fig. 2). The ridges are partly dissected by small drainages and marshes. The highest altitude of the main ridges generally is 10 to 15 $\mathrm{ft}$ above NAVD 88, with Confederate Ruins ridge decreasing in altitude to the east. South of Passmore Creek, ridges are shorter, narrower, and lower altitude.

The sediments of Jamestown Island are fluvial, estuarine, and marginal marine deposits of Pleistocene and Holocene age (Johnson, 2007). The Lynnhaven Member of the Tabb Formation forms the Church Point and Confederate Ruins ridges (Johnson, 2007). It consists of a basal, gravelly, coarse-grained quartz sand with small amounts of mica, feldspar, and heavy minerals. The formation grades upward in a sequence of clayey and silty fine- to very fine-grained sand or a sandy to silty clay covered by soil. The Poquoson Member of the Tabb Formation forms the ridges south of Passmore Creek. It grades upward from a basal, coarse-grained sand to a mixture of sand, silt, and clay. Marshes occupy valleys between ridges and are filled with organic-rich silt and sand or mud (Johnson, 2007). Pleistocene and Holocene ridge and marsh sediments are underlain by the late Miocene Eastover Formation, a marine unit consisting of fine-grained sand, silt, and clay. Because of the eastward dip in sediment across the Atlantic Coastal Plain, contacts between different sediment types are at altitudes that decrease slightly to the east across the island.

\section{Ecological Resources}

Ecological resources across the island include diverse wetland and forested-upland ecosystems that provide habitat for a variety of plant and animal species, many of which are rare, threatened, and (or) endangered (Thornberry-Ehrlich, 2016). Wetland ecosystems consist of extensive tidal, freshwater-to-oligohaline marshes that cover about two-thirds of the island (fig. 2). Marshes typically are fresh in the upper reaches of most drainages but transition to oligohaline in the lower reaches.

Pine and mixed-hardwood forests cover adjacent upland ridges that are bordered by the marshes. As sea level rises, marshes encroach into these forests (fig. 3A). The composition of the marshes changes as the water becomes more saline and species respond to the increasing salinity. Shoreline erosion cuts into adjacent marshes and forests along the edge of many water bodies.

\section{Groundwater-Monitoring Strategy}

The purpose of the groundwater-monitoring strategy was twofold: (1) to identify differences in the hydrology and chemistry of groundwater across Jamestown Island, and (2) to evaluate changes in groundwater levels, salinity, and chemistry because of groundwater recharge, tides, storm surges, and sea-level rise. Vertical and lateral heterogeneity was identified during well construction in both sediment characteristics and hydrologic and chemical conditions. These initial observations helped to determine the locations of additional monitoring wells and piezometers. Data were collected periodically throughout the entire well network to identify the effects of sediment characteristics on hydrology and groundwater chemistry and to guide site selection for future monitoring. Specific conductance was used as a surrogate for salinity of water samples.

\section{Monitoring Network}

The monitoring network was designed to evaluate spatial differences in the major hydrologic and chemical environments to which island resources are exposed, and by which they may be adversely affected. The monitoring network 


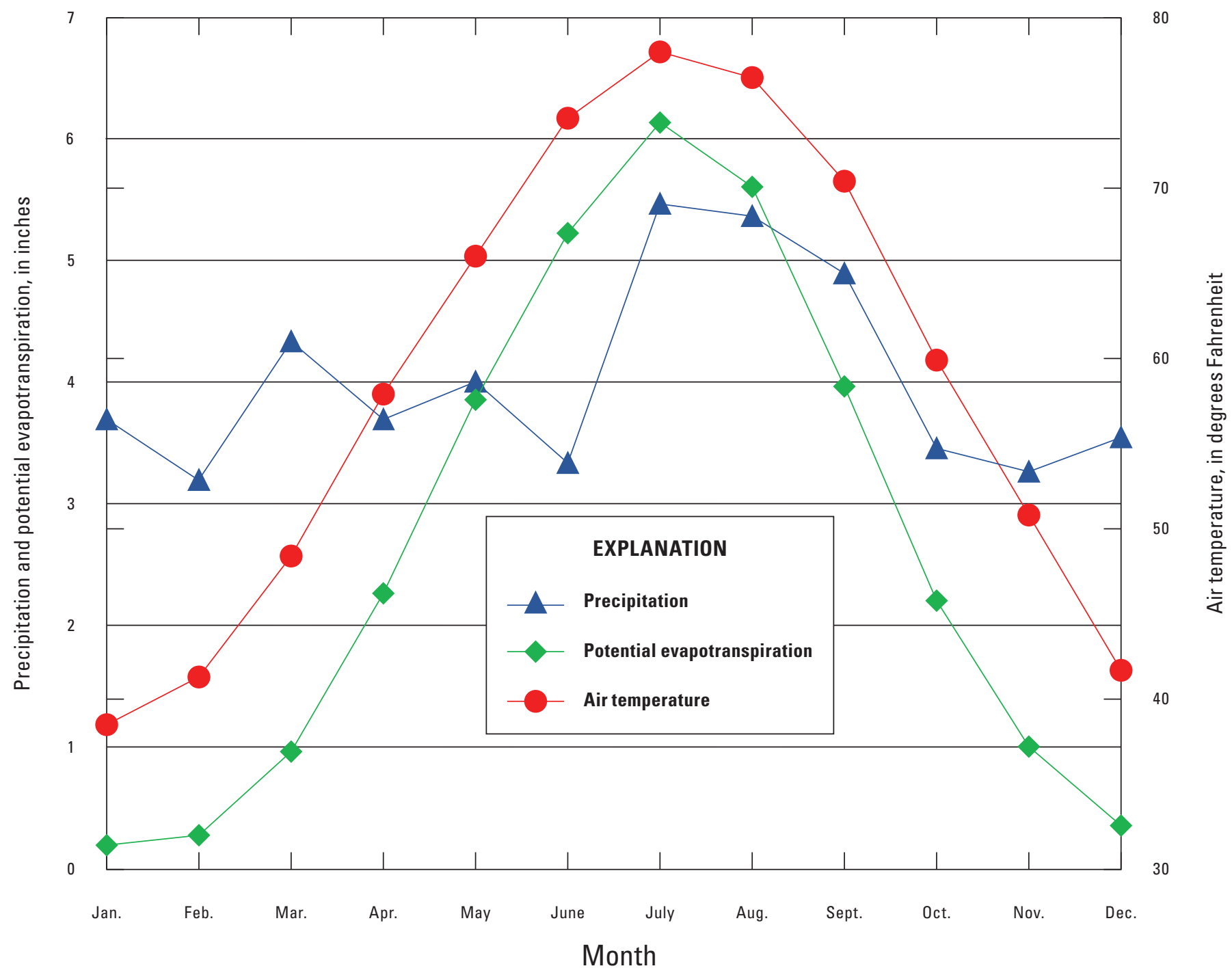

Figure 4. Graph showing the average monthly air temperature, precipitation (National Oceanic and Atmospheric Administration [NOAA], 2018), and potential evapotranspiration (University of Virginia, 2000) for 1981 through 2010 at NOAA weather station USC00449151, Williamsburg, Virginia.

consists of 45 wells and piezometers in 2 individual clusters and 3 lines (transects) of clustered and individual wells and piezometers (fig. 2). Transects extend from marshes, or the river, to or across upland ridges (fig. 5).

Two factors affected site selection for the monitoring network - the end of the island and the proximity of marshes to uplands. The east end of the island is affected more by sealevel rise, tides, and storm surges than the west end, because land-surface altitude is lower, upland ridges are narrower, and the ocean is closer. The proximity of marshes to uplands was important because of the potential for influence of highersalinity marsh water on fresher water underlying the uplands.

All monitoring sites were located adjacent to known archaeological areas to monitor environments to which artifacts likely are exposed, while minimizing potential damage to the artifacts from well and piezometer construction. Two individual clusters were installed along the Jamestown Loop
Road (hereafter "tour road" in this report), one at the west end of the island (Tour Road 1, TR-1, fig. 2), and the other at the east end of the island (Tour Road 2, TR-2, fig. 2). The purpose of the two clusters was to allow comparison of salinity and chemistry through the full thickness of the Surficial aquifer at both ends of the island.

Three transects (Island House, Black Point, and Earthworks) were constructed to represent the sequence of hydrologic and chemical environments from marshes, or the edge of the river, into the forested uplands. The Island House transect near the west end of the island extends from the marsh to near the center of Church Point ridge (figs. 2, 5A). This forested ridge has one of the highest land-surface altitudes on the island. The other two transects are at the east end of Confederate Ruins ridge. The Black Point transect extends from a marsh to the north, across a low-altitude, forested ridge, and into the marsh to the south (figs. 2, 5B). The Earthworks 
transect extends west from the river along a low-altitude, forested ridge (figs. 2, 5C). Two sites beyond the west end of the Earthworks transect extend north from the marsh/forest edge into the marsh. The two sites are at the south edge of the marsh that is south of Black Point and are approximately aligned with the Black Point transect.

The locations of sites within each transect were selected to represent different hydrologic and chemical characteristics. Hydrologically, the forested-upland ridges represent areas dominated by fresh groundwater recharge. Marsh sites represent zones where fresh groundwater from the uplands can mix with saline water that enters the aquifer laterally or from inundation. Fresh groundwater recharge is limited in the marshes by the shallow water table and inundation by tides. Chemically, sites included the anoxic, saline conditions beneath marshes; the oxidized, freshwater recharge of the uplands; and the zones where these waters mix. Marsh sites were installed as far into marshes as possible, which was limited to about 20-40 ft by soft mud. Sites at the marsh/forest edge represent the likely transition from the anoxic to the oxic zone. Multiple sites were located across the forested upland from the marsh, to or beyond the ridge, to represent different parts of the oxidized zone. The distance between sites across the upland varied. Some sites had multiple wells and (or) piezometers clustered and open to different depths.

\section{Well Construction}

All wells and piezometers were open to the Surficial aquifer. Solid-casing, open-ended piezometers were installed in low-permeability sediment to allow the collection of samples that minimized aeration and represented the chemistry of groundwater from these intervals. Aeration is less likely in solid-casing, open-ended piezometers because water fills piezometers from the bottom. Except for the two deepest wells, wells and piezometers were constructed in 4-in.-diameter, hand-bored holes.

The two deepest wells (TR-1W25 and TR-2W29; table 1) were constructed in 8-in.-diameter, machine-bored holes, 5 to $10 \mathrm{ft}$ below the bottom of the coarse-grained sand and gravel into the underlying clay, silt, and fine-grained sand of the Eastover Formation. This permitted the well screen to be open to the bottom of the coarse-grained sand and gravel of the Tabb Formation for sampling.

Piezometers were constructed of 2-in.-diameter polyvinyl chloride (PVC) well casings inserted into the boreholes after the water that contained sediment had been pumped from the hole. About 6 in. of $\# 2$ well-filter sand was poured into the borehole (fig. 6). The open-ended PVC casing then was inserted into the borehole and pushed slightly into the sand. Another 6 to 12 in. of sand was poured into the annular space

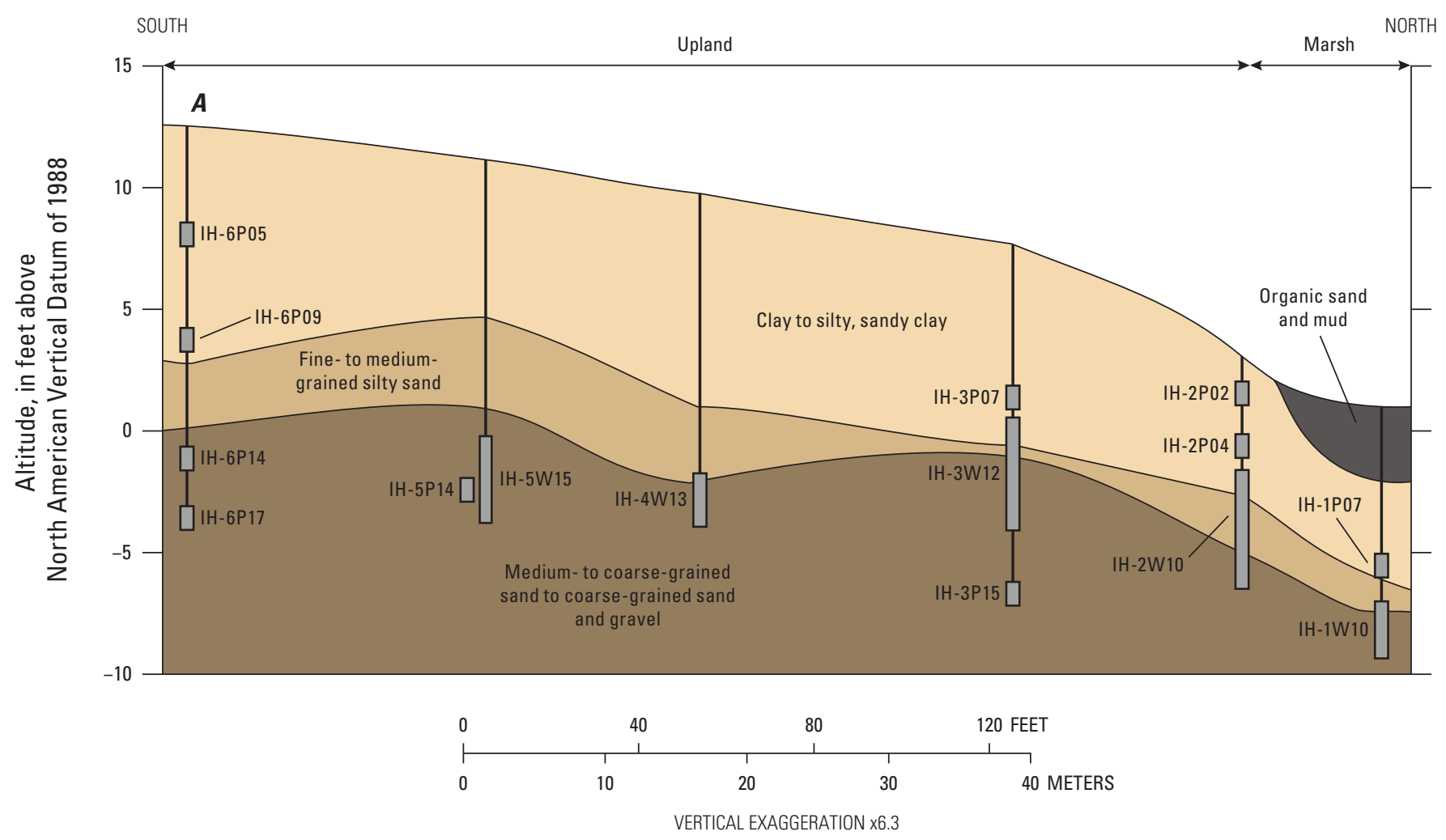

Figure 5. Sections showing the depth of contacts between major sediment types, screened intervals of wells, and sand intervals at the bottoms of piezometers in transects at $A$, the Island House, $B$, Black Point, and $C$, the Earthworks, Jamestown Island, Colonial National Historical Park, Virginia. 


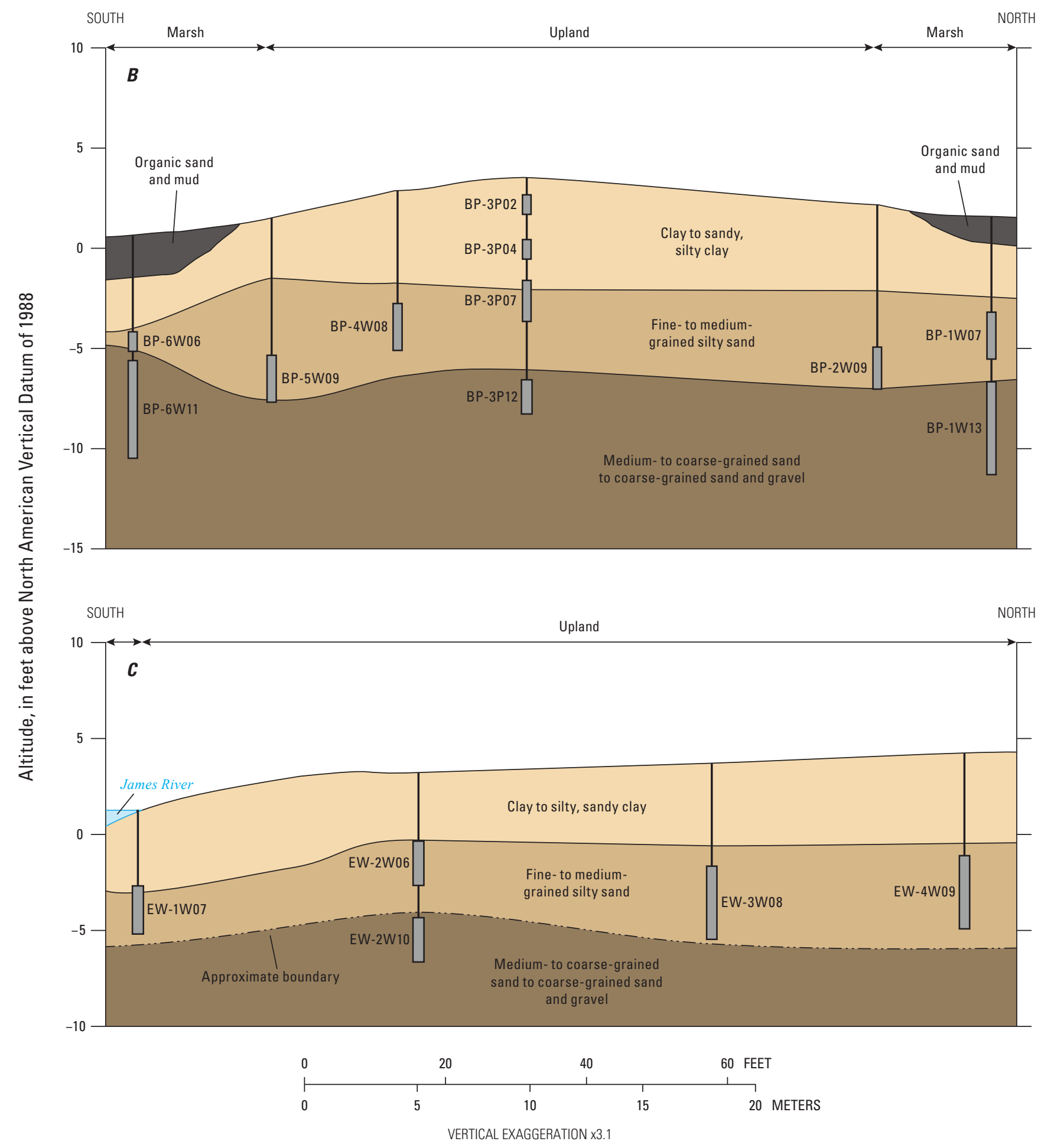

Figure 5. Sections showing the depth of contacts between major sediment types, screened intervals of wells, and sand intervals at the bottoms of piezometers in transects at $A$, the Island House, $B$, Black Point, and $C$, the Earthworks, Jamestown Island, Colonial National Historical Park, Virginia. —Continued 
Table 1. Description of wells and piezometers in the monitoring network, Jamestown Island, Colonial National Historical Park, Virginia.

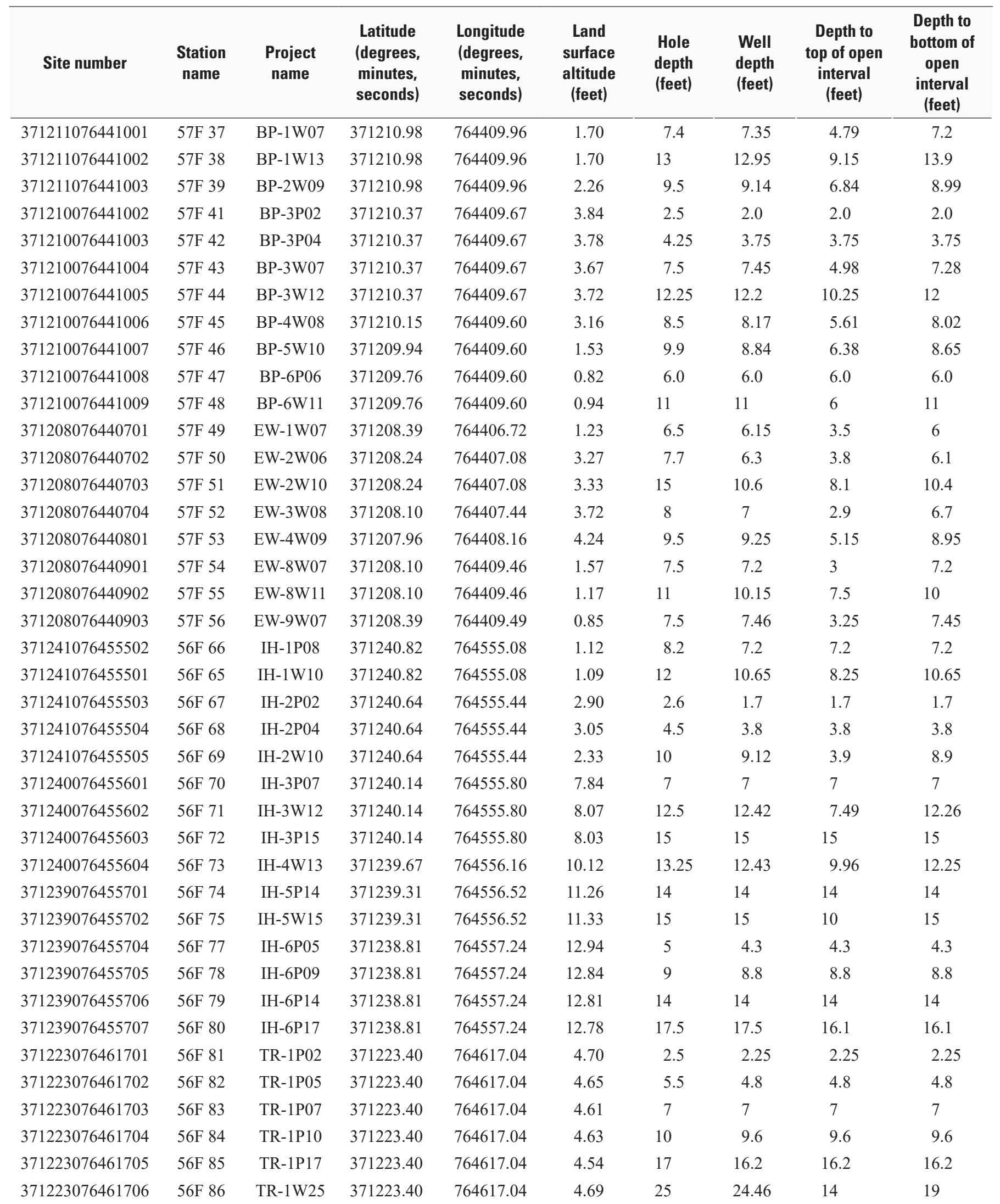


Table 1. Description of wells and piezometers in the monitoring network, Jamestown Island, Colonial National Historical Park, Virginia.-Continued

\begin{tabular}{cccccccccc}
\hline Site number & $\begin{array}{c}\text { Station } \\
\text { name }\end{array}$ & $\begin{array}{c}\text { Project } \\
\text { name }\end{array}$ & $\begin{array}{c}\text { Latitude } \\
\text { (degrees, } \\
\text { minutes, } \\
\text { seconds) }\end{array}$ & $\begin{array}{c}\text { Longitude } \\
\text { (degrees, } \\
\text { minutes, } \\
\text { seconds) }\end{array}$ & $\begin{array}{c}\text { Land } \\
\text { surface } \\
\text { altitude } \\
\text { (feet) }\end{array}$ & $\begin{array}{c}\text { Hole } \\
\text { depth } \\
\text { (feet) }\end{array}$ & $\begin{array}{c}\text { Well } \\
\text { depth } \\
\text { (feet) }\end{array}$ & $\begin{array}{c}\text { Depth to } \\
\text { top of open } \\
\text { interval } \\
\text { (feet) }\end{array}$ & $\begin{array}{c}\text { Depth to } \\
\text { bottom of } \\
\text { open } \\
\text { interval } \\
\text { (feet) }\end{array}$ \\
\hline 371203076442101 & $57 \mathrm{~F} 57$ & TR-2P05 & 371202.92 & 764421.48 & 3.99 & 5 & 4.75 & 4.75 & 4.75 \\
371203076442102 & $57 \mathrm{~F} 58$ & TR-2P09 & 371202.92 & 764421.48 & 4.06 & 9.5 & 9.2 & 9.2 & 9.2 \\
371203076442103 & $57 \mathrm{~F} 59$ & TR-2P07 & 371202.92 & 764421.48 & 4.36 & 13 & 13 & 8 & 13 \\
371203076442104 & $57 \mathrm{~F} 60$ & TR-2W29 & 371202.92 & 764421.48 & 4.46 & 29 & 29 & 14 & 19 \\
\hline
\end{tabular}

between the casing and the borehole wall. The sand and casing were placed carefully into the hole to minimize dislodging sediment from the borehole wall that could plug the filter sand. Bentonite was poured into the borehole to fill the annular space from the top of the filter sand to land surface to prevent water from flowing vertically through the annular space. As the bentonite was poured into the annular space, the casing was shaken to minimize bridging that could create voids and allow vertical flow.

Wells were constructed of 2-in.-diameter PVC casings and screens, which were inserted into the boreholes after the water that contained sediment had been pumped from the hole. Screens have 0.010 -in.-width openings and lengths that range from about 2 to $5 \mathrm{ft}$, depending on the length of the sediment

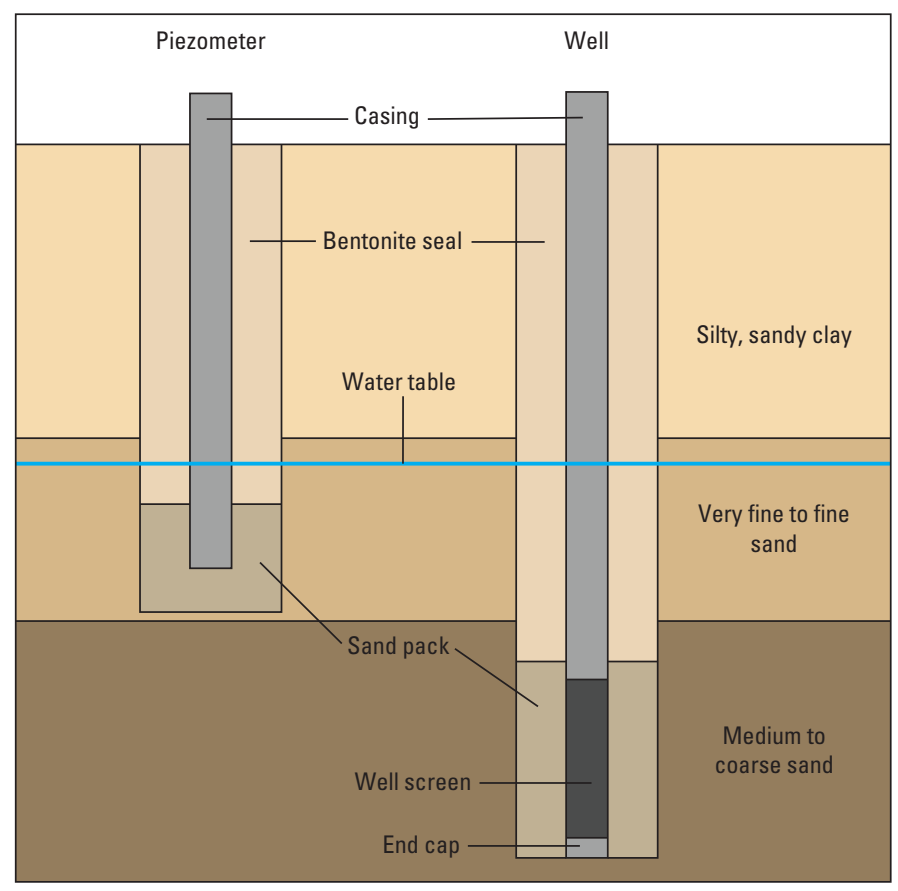

Figure 6. Schematic showing the typical construction of a piezometer (left) and a well (right), Jamestown Island, Colonial National Historical Park, Virginia. interval to which the well was to be open (fig. 6). A PVC cap was placed on the bottom of the screen. Lightweight sheer fabric was stretched over the outside of each screen and tied in place above the screen to minimize plugging of screen openings with sediment. The screen was placed carefully into the borehole to minimize dislodging sediment from the borehole wall. Number 2 well-filter sand was poured carefully into the annular space to about 6-12 in. above the top of the screen. The well casing and screen were shaken gently while the sand was poured to minimize bridging of the sand across the annular space. As described above for piezometers, the remaining hole was filled with bentonite.

Water was then pumped from the well or piezometer to remove sediment from the filter sand and screen openings so that water levels and samples represented the adjacent aquifer. Well and piezometer casings generally were constructed to extend 1-3 ft above land surface and capped to minimize water flowing into the casing during inundation by tides and storm surges. A small hole was drilled into the cap to maintain equilibrium with atmospheric pressures as groundwater levels declined and rose.

\section{Well and Piezometer Nomenclature}

Wells and piezometers were named to identify their location, whether it is a well (W) or piezometer (P), and its approximate depth in feet (a two-digit number). The location includes two parts - the location of the individual cluster or transect and the location of well or piezometer within the transect. For the location of individual clusters, sites were identified as "TR-1" for the western tour-road cluster and "TR-2" for the eastern tour-road cluster (table 1). Transects were identified by "IH" for Island House, "BP" for Black Point, and "EW" for Earthworks. Sites of individual wells and clusters within transects were numbered sequentially from the north at the Island House and Black Point and the east at the Earthworks. Thus, BP-3W12 is the 12-ft-deep well at the third site from the north at Black Point, and BP-3P07 is the 7-ft-deep piezometer at the third site from the north at Black Point. 


\section{Groundwater-Monitoring Parameters and Frequency}

Groundwater levels were measured using an electric water-level tape at approximately bimonthly intervals in wells and piezometers that contained water. Water levels were measured as depth below a fixed measuring point, marked on the top of the PVC casing, in all wells and piezometers before water-quality sampling began. Water-quality parameters were measured with a YSI EXO1 4-parameter (water temperature, dissolved oxygen, specific conductance, and $\mathrm{pH}$ ) water-quality sonde, with each sensor standardized, was lowered into the well or piezometer and placed about 6 in. above the top of the well screen or bottom of the piezometer. The intake of a peristaltic pump was placed above the sonde near the water surface in the well or piezometer. Water-quality parameters were measured in situ with the sonde positioned at a depth between the pump intake and the top of a well screen or bottom of a piezometer. Water-quality parameters were recorded until 2-3 well volumes were purged from each sampling location. Groundwater samples were collected from selected wells and piezometers and processed according to USGS protocols (U.S. Geological Survey, 2012) and sent to the USGS National Water Quality Laboratory for analysis of major-ion concentrations and dissolved solids. Data on well construction and major-ion concentrations are stored in the USGS National Water Information System database (https://waterdata.usgs. gov/nwis). Data on groundwater levels, temperature, specific conductance, $\mathrm{pH}$, and dissolved-oxygen concentrations are reported in a USGS data release (Ladd, 2020).

The well-purging technique described is a modification of USGS sampling protocols (U.S. Geological Survey, 2012) and was used to obtain a sample representative of aquifer water from the interval adjacent to the piezometer or well-screen opening, while minimizing vertical and lateral flow of water within the aquifer. This is critical because of the large vertical and lateral differences in water quality over short distances and the potential for macropore flow in the Surficial aquifer. Because of these differences and the potential for induced flow from other quality zones, stability of field parameters could be difficult to obtain.

Krieger and others (1957) classify the degree of salinity in terms of dissolved solids, which include freshwater, slightly saline, moderately saline, saline, and brine (table 2), terms that are used in the remainder of this report. Salinity is defined in terms of dissolved solids because ions other than sodium and chloride contribute to salinity. Because the specific conductance of water with a given salinity depends on the ionic species and concentration in solution, relations of specific conductance to the degree of salinity differ by waters. Consequently, the relations of salinity and dissolved solids to specific conductance were derived from the specific conductance and dissolved solids concentrations of groundwater samples collected November 20-22, 2017 (fig. 7), and were compared to degrees of salinity (table 2). Because chloride is a conservative (minimally reactive) constituent and is the major anion in seawater, the relation of specific conductance to chloride concentration for those samples (fig. 7) also was compared to the degree of salinity (table 2). The relations of dissolved solids and chloride to the specific conductance of groundwater were similarly uniform, with correlation coefficients $\left(\mathrm{R}^{2}\right)$ of 0.96 and 0.95 , respectively. Although several samples can be classified as freshwater, most would be classified as slightly or moderately saline (fig. 7). Because no sample could be classified as saline based on dissolved-solids concentrations, the specific conductance and chloride concentrations of the lower and upper boundaries of the saline classification in table 2 were extrapolated from the data and regression equation in figure 7 and are shown in parentheses. The boundary between saline and brine is that of seawater with a typical chloride concentration of 19,400 milligrams per liter (mg/L), compared to $18,900 \mathrm{mg} / \mathrm{L}$ extrapolated from the regression equation.

\section{Hydrology}

On Jamestown Island, surface waters and groundwaters are interconnected so that they effectively function as a single

Table 2. Relations of degrees of salinity to dissolved-solids concentrations (Krieger and others, 1957) and to specific conductance and chloride concentrations in groundwater samples collected November 20-22, 2017, Jamestown Island, Colonial National Historical Park, Virginia.

$[<$, less than; (), enclosed values extrapolated beyond sample values based on correlation in figure 7]

\begin{tabular}{|c|c|c|c|}
\hline Degree of salinity & $\begin{array}{l}\text { Dissolved solids concentration, in } \\
\text { milligrams per liter }\end{array}$ & $\begin{array}{l}\text { Specific conductance, in } \\
\text { microsiemens per centimeter } \\
\text { at } 25 \text { degrees Celsius }\end{array}$ & $\begin{array}{l}\text { Chloride concentration, in } \\
\text { milligrams per liter }\end{array}$ \\
\hline Freshwater & $<1,000$ & $<1,740$ & $<540$ \\
\hline Slightly saline & 1,000 to $<3,000$ & 1,740 to $<5,210$ & 540 to $<1,620$ \\
\hline Moderately saline & 3,000 to $<10,000$ & 5,210 to $(<17,400)$ & 1,620 to $(5,390)$ \\
\hline Saline & 10,000 to 35,000 & $(17,400)$ to $(60,800)$ & $(5,390$ to 18,900$)$ \\
\hline Brine & $>35,000$ & $(>60,800)$ & $(>18,900)$ \\
\hline
\end{tabular}



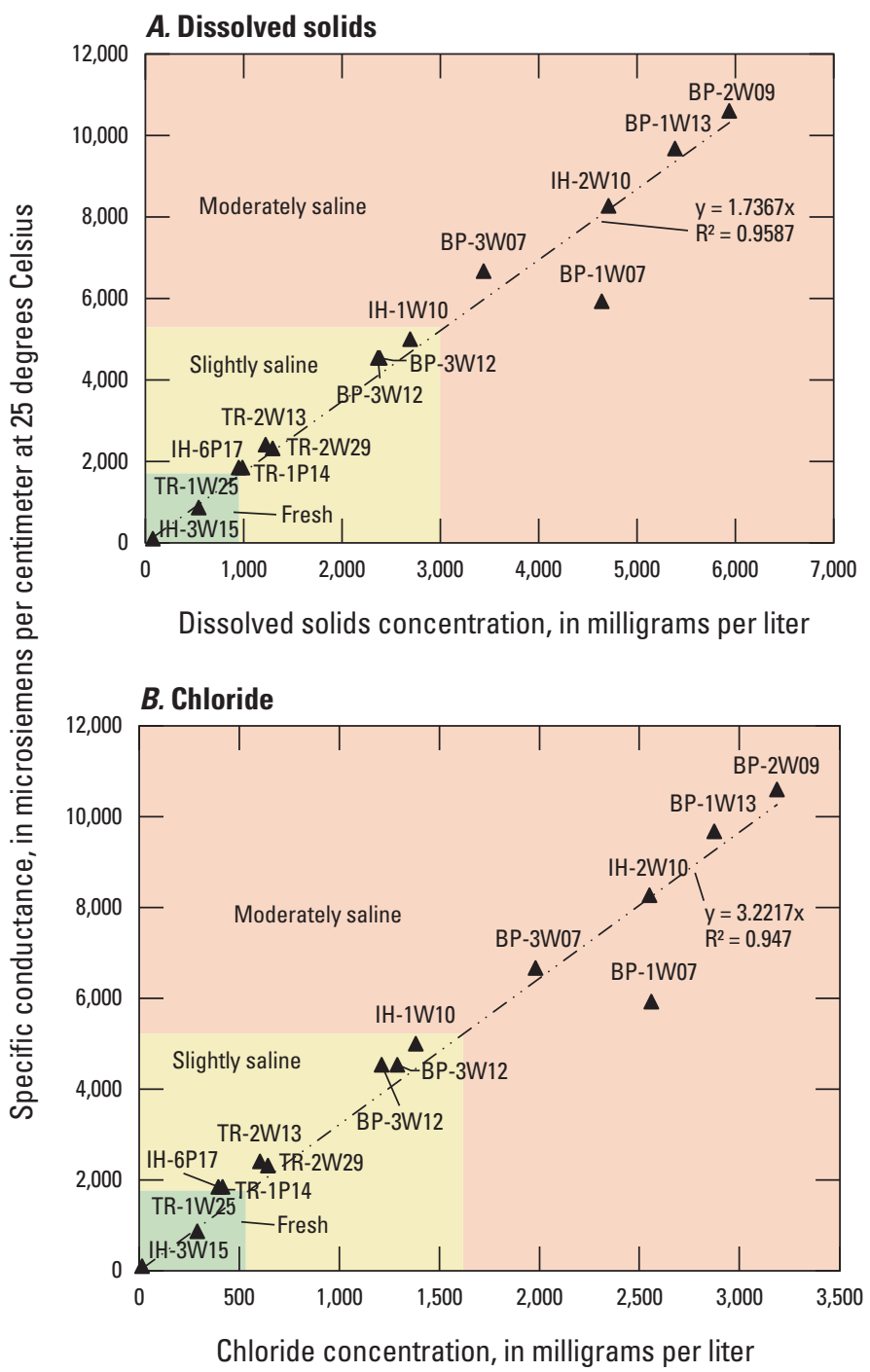

Figure 7. Graphs showing the relations of $A$, dissolved solids and $B$, chloride concentrations to specific conductance to characterize the salinity of groundwater collected November 20-22, 2017, Jamestown Island, Colonial National Historical Park, Virginia.

hydrologic system. The surface-water system consists of water bodies that surround the island and those within the interior of the island. Most surface waters are tidal but have a net direction of flow caused by discharge from their watersheds. The Surficial aquifer is the primary aquifer affecting island hydrology and chemistry; no other aquifers are exposed on the island. The combined groundwater and surface-water system drains and inundates marshes and uplands across the island in response to precipitation, groundwater recharge, evapotranspiration (ET), tides, storm surges, and sea-level rise.

Tides at the Jamestown Ferry Pier tide station follow a semidiurnal pattern; the range between the daily highest high and lowest low tides averaged $2.17 \mathrm{ft}$ from August 13, 2015, through October 1, 2018 (U.S. Geological Survey, 2021. The altitude of all tides for the period averaged $0.54 \mathrm{ft}$ above NAVD 88 . The daily lowest low tide ranged from -3.26 to
$3.30 \mathrm{ft}$ above NAVD 88 and averaged $-0.54 \mathrm{ft}$ above NAVD 88 (fig. 8). The daily highest high tide ranged from -0.72 to $5.16 \mathrm{ft}$ above NAVD 88 (fig. 8) and had both an average and a median of $1.63 \mathrm{ft}$ above NAVD 88. The highest tide for the period was $5.16 \mathrm{ft}$ above NAVD 88 at 18:18 Eastern Daylight Time on October 4, 2015, as a result of the combined effects of Hurricane Joaquin and an upper-level, low-pressure system. By comparing the altitude of land surface at wells, archaeological sites, and other locations on the island with the distribution of highest high tides (fig. 8), the depth and frequency of inundation of sites during this period were estimated by assuming the altitude of the water surface at the Jamestown Ferry Pier tide station was the same as that around the island.

\section{Surface Waters}

Surface waters surrounding the island include the James River, Sandy Bay, the Back River, and the Thorofare (fig. 2). The James River forms the southwestern and southeastern shores of the island with a net flow to the southeast toward Chesapeake Bay; it drains 9,404 square miles $\left(\mathrm{mi}^{2}\right)$ at the Jamestown Ferry Pier tide station just west of the island. Sandy Bay, which forms the northwestern shore of the island, has a net flow east into the Back River and south into the James River. The net flow from the Back River is east into the Thorofare; both form the northeastern shore of the island. The net flow from the Thorofare is southeast into the James River.

Two principal stream networks drain uplands and marshes of the interior of the island (fig. 2). The Pitch and Tar Swamp has a net flow east into Kingsmill Creek, which has a net flow northeast into the Thorofare (fig. 2). Passmore Creek has a net flow east to the James River and receives flow from several small creeks that drain marshes surrounding the ridges to the south and west. Several other small creeks drain marshes and uplands across the island.

Complex interactions among river discharge, tides, winds, storm surges, and sea-level rise affect the salinity of James River water and the location of the salinity front. As saline water from Chesapeake Bay and the Atlantic Ocean mixes with fresh river water, salinity and density gradients form a salt-water wedge, which continually shifts up and down the river (for example, Rice and others, 2012). James River discharge typically is greatest from February into April, which alters tides and reduces salinity. At the onset of ET in April to early May (fig. 4), discharge begins to decline to seasonal lows (July into September), increasing salinity near Jamestown. The interplay between freshwater discharge from the watershed and saline water from the bay and ocean changes continuously. Groundwater levels and salinity on the island respond to those changes to different degrees, depending on location.

Nor'easters, tropical systems, and other low-pressure storm systems can alter tides and salinity depending on their strength and position relative to the mouth of the bay and the James River. Effects during a single storm can change as the storm proceeds. Strong storms that approach the coast from the south have winds that range from southeast to northeast and drive saline water into the James River. These weather 
events cause storm surges, which can inundate extensive land areas, cause catastrophic damage, and push saline water up the river. Storm surges that peak during high tide inundate the largest land surface area, cause the most damage, and push saline water the farthest upstream. A storm that enters the mouth of Chesapeake Bay typically causes a greater surge and higher salinity than an equivalent-strength storm that is offshore or inland. As a storm moves north, wind direction near the island shifts to the west or northwest and pushes water downstream, decreasing water levels and salinity. Large storms across the James River watershed cause high discharge, pushing saline water downstream, which can occur days after the storm is over.

\section{Groundwater}

A regional aquifer system extends across the Atlantic Coastal Plain of Virginia, from land surface to depths of about
1,250 ft beneath Jamestown Island (McFarland and Bruce, 2006). It consists of laterally extensive aquifers that have enough hydraulic conductivity to yield hundreds of gallons of water per minute to wells. The Potomac aquifer is the deepest and highest yielding of these aquifers and is used for most large water supplies. The shallower Piney Point aquifer is used for water supply in James City County where Jamestown Island is located. Confining units separate the aquifers; the Saint Marys confining unit is the uppermost confining unit with its top at a depth of about $60 \mathrm{ft}$ below land surface beneath the island (McFarland and Bruce, 2006). This confining unit inhibits, but does not prevent, groundwater flow between the underlying aquifers and the overlying YorktownEastover and Surficial aquifers.

The Surficial aquifer at Jamestown is recharged directly by precipitation, and it discharges to the surrounding surface waters. The Surficial aquifer responds to the effects of tides, storm surges, and sea-level rise on the James River. This

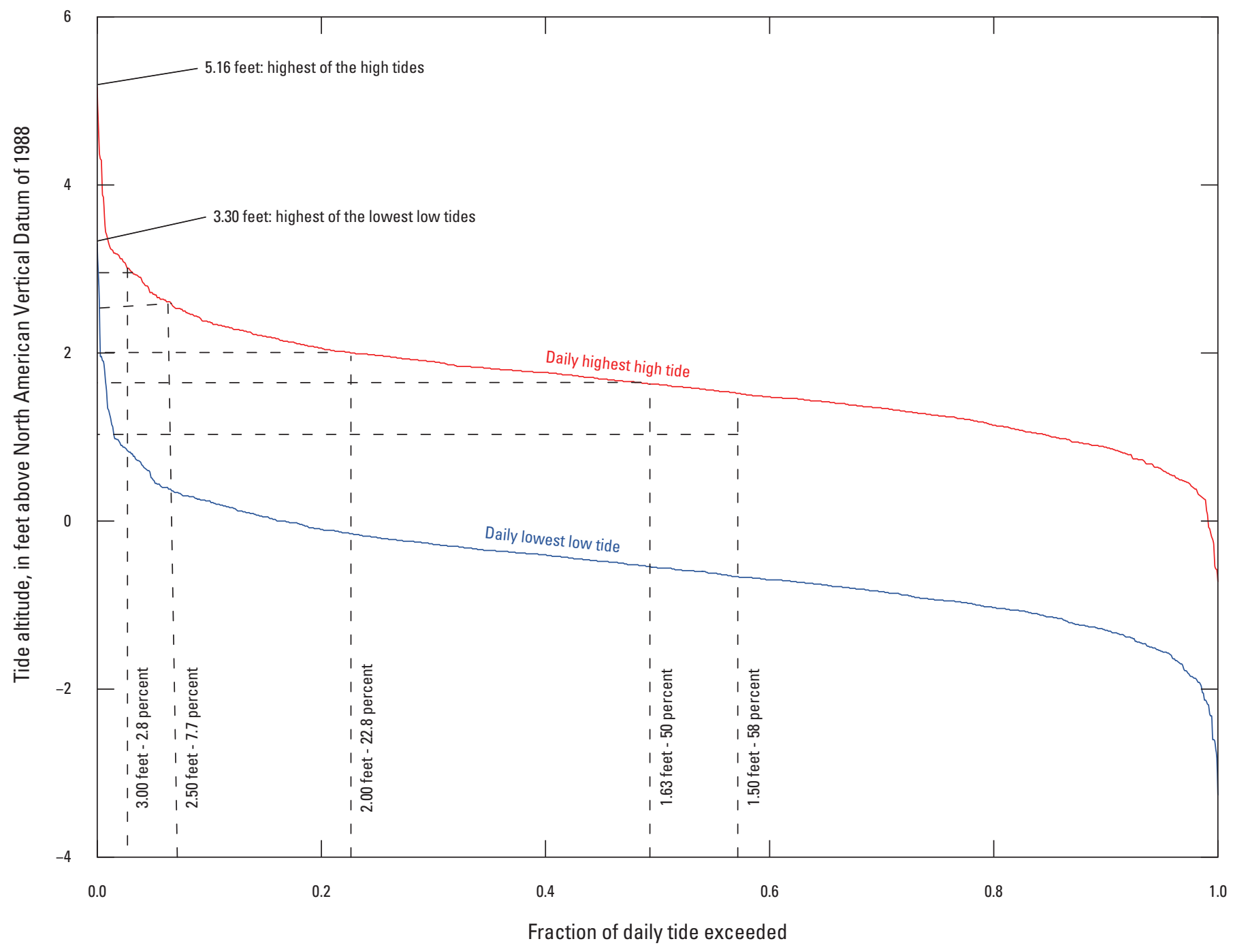

Figure 8. Graph showing the distributions of the daily highest high and lowest low tides in the James River at Jamestown Ferry Pier, Va. (station 02042770), August 13, 2015, through October 1, 2018, Jamestown Island, Colonial National Historical Park, Virginia. 
exchange takes place because the James River channel is incised into the Surficial and underlying Yorktown-Eastover aquifers.

At Jamestown Island, the Surficial aquifer consists of organic sand and mud that fill the valleys beneath the marshes (Thornberry-Ehrlich, 2016); the aquifer is laterally and vertically heterogeneous. Beneath the uplands, the lower part of the Surficial aquifer consists of coarse-grained sand with the basal gravel overlain by fine- to very fine-grained sand. At some sites, the change from coarse-grained sand to fine- to very fine-grained sand is gradational; at others, it is a distinct boundary. A distinct contact separates these sediments from overlying clayey, sandy silt, which grades to silty, sandy clay at land surface. Where the land-surface altitude decreases, the upper clayey part of the aquifer is absent. Beneath the marshes, the upper part of this sequence has been eroded so that the organic sand and marsh mud overly the middle and lower parts of the upland sequence.

The Surficial aquifer is an unconfined, water-table aquifer throughout most of the Atlantic Coastal Plain; however, fine-grained interbeds can cause locally confined conditions (McFarland and Bruce, 2006). Such is the case at Jamestown Island because of the low permeability of the marsh sediments and the clay, silt, and fine-grained sand that form the nearsurface sediments that overlie coarse-grained sand and gravel. These semiconfined or confined conditions underlie most of the island, as marshes compose about two-thirds of the island's landcover. Clayey near-surface sediments are locally the thickest beneath the island's uplands with the highest altitudes. When hand-boring holes during well and piezometer construction, water did not enter holes bored to the bottom of the clayey sediment. Once the borehole penetrated the underlying, saturated, fine- to very fine-grained sand, water entered most boreholes and rose 6 to 12 in. into the clayey sediment.

The hydraulic connection between the Surficial aquifer and surrounding surface waters depends on the depth of the stream channels and the extent of marshes between the surface waters and the uplands (Johnson and Hobbs, 2001). The James River has a variable-depth channel, ranging from about 2 to 10 $\mathrm{ft}$ near the southeast end of the island to greater than $50 \mathrm{ft}$ off the southwest end of the island (U.S. Geological Survey, 1983, 1984). At the southeast end of the island, the best connection between the river and the Surficial aquifer is about a half mile into the river where the channel is dredged. At the southwest end of the island, where the channel is deepest and borders the upland, the river connects directly to the more permeable parts of the Surficial aquifer (fig. 9). Because these waters border marshes and have shallow channels, the less permeable clayey sediment and the organic sand and mud underlying the marshes limit connection of these waters to the more permeable parts of the Surficial aquifer (fig. 9). Parts of the meandering channels of some of these streams, however, border upland ridges and can connect directly to the more permeable parts of the Surficial aquifer (fig. 9).

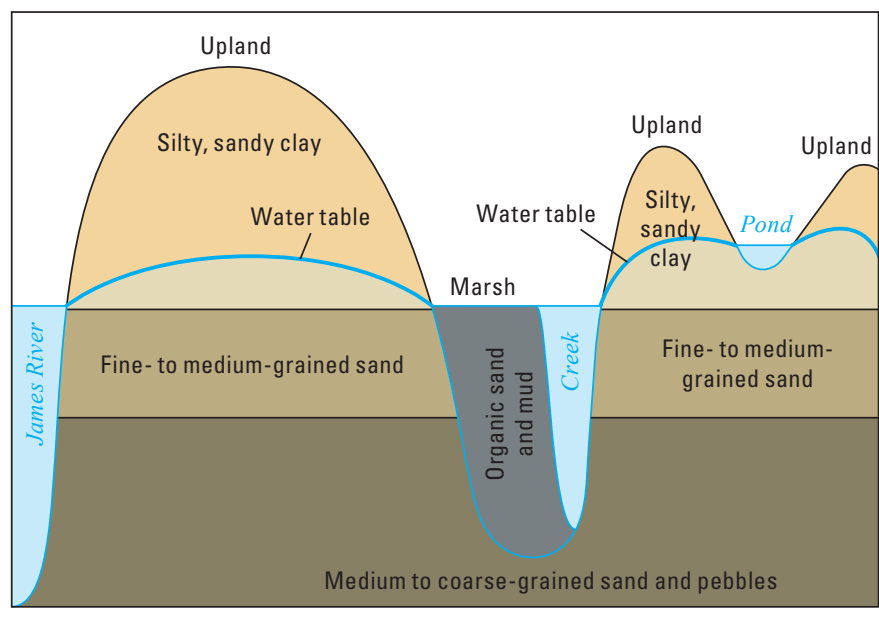

NOT TO SCALE

Figure 9. Schematic showing the interconnection between sediment of differing permeability in the Surficial aquifer with the James River and the channels of smaller streams, Jamestown Island, Virginia (modified from Johnson and Hobbs, 2001).

\section{Hydrologic and Chemical Processes}

Sea-level rise alters numerous hydrologic and chemical processes in surface water, groundwater, and (or) unsaturated soil. Processes differ temporally and spatially across the island depending on the following factors: (1) the amount and timing of freshwater recharge, (2) land-surface altitude and slope, (3) lateral and vertical sediment characteristics, (4) the presence of marshes, (5) the distance from surface waters, and (6) the degree of hydraulic connection between surface water and the aquifer. Because surface waters can be observed visually, the public, managers, and even scientists tend to attribute ongoing effects of sea-level rise to surface-water processes. Some changes, however, can occur from subsurface processes.

Tides, winds, storm surges, and sea-level rise cause shoreline erosion, inundation of the land surface, and changes in salinity. Shoreline erosion is a continual natural process as river channels migrate, and tides, wind, and storm surges create currents and waves. Tides continually cause inundation of the land surface, particularly across marshes. As sea level rises, the rates and locations of shoreline erosion change, the depth and duration of inundation increases, and salinity increases. Storm surges can create more immediate effects than those of sea-level rise. Rising sea level, however, increases the effects of individual surges.

Variation in discharge, tides, winds, storm surges, and sea level are the main processes that control surface-water levels and salinity. These competing factors make identification of the controlling processes difficult with short periods of record. Large, persistent changes, however, facilitate identification of the primary controlling processes and the characteristics of the responses. 
The Surficial aquifer at Jamestown Island has the following three sources of water: (1) recharge from the land surface through the unsaturated zone by precipitation, (2) recharge from the land surface through the unsaturated zone by freshto-saline water from tides and storm surges that inundate the land, and (3) lateral flow of fresh-to-saline water through the aquifer from adjacent surface waters. Consequently, the salinity and other chemical characteristics of each source, and the physical characteristics of the sediment of the unsaturated zone and Surficial aquifer through which the water flows, control the hydrology and water chemistry spatially and temporally. The effects of the different sources at a particular site depend on land-surface altitude and slope, lateral and vertical differences in the permeability of unsaturated zone and aquifer sediment, proximity to surface waters, and the degree of the hydraulic connection of the surface waters and aquifer.

Recharge by precipitation occurs across the land surface and is the main source of water to the high-altitude uplands because these areas seldom are inundated. Recharge from precipitation typically flows laterally through the Surficial aquifer from the uplands toward low-altitude wetlands and marshes (Speiran, 1996, 2010). Fresh groundwater flow toward the low-relief, lowland marshes is limited because the Surficial aquifer thins, and the low topographic relief does not provide the hydrologic gradients needed for flow from the base of the upland, beneath the marshes, to surface waters. This flow limitation forces groundwater to discharge to the lowland marshes near the base of the upland (Speiran, 1996, 2010). The greater density of saline groundwater beneath the marshes also limits flow of freshwater beneath the lowland marshes. Changing tides cause the direction of this limited flow beneath the marshes to alternate between flowing away from the uplands toward surface waters and from surface waters toward the uplands.

Fresh-to-saline water from tides and storm surges can recharge the aquifer in several ways. As storm water inundates marshes and uplands, recharge can occur vertically from land surface; the recharge water can push water under the marshes laterally and vertically into the Surficial aquifer. The amount of recharge from storm surges depends on the following factors: (1) the amount of freshwater recharge, (2) the altitude and slope of the land surface, (3) the permeability of the sediment and proximity of surface waters to the aquifer, (4) the degree of hydraulic connection of surface waters with the aquifer, and (5) the magnitude of tides and storm surges. The frequency, depth, and duration of inundation depends on land-surface altitude and the frequency, height, and duration of tides and storm surges. The hydraulic gradient and the hydraulic conductivity in marshes is low, which limits the lateral and vertical flow of freshwater and saline water.

In low permeability sediments, water levels are slow to respond to tidal signals. When a marsh is inundated and drains, water is exchanged between groundwater and surface water as tides rise and fall. Because the organic-mud fill and the underlying clay and silt have low permeability, and the period between high and low tides is only 6 hours, these sediments drain little and remain nearly saturated.

The zone of influence that surface waters exhibit on surrounding groundwater levels and salinity is a function of the aquifer-sediment permeability surrounding the surface water feature and changes in surface-water stage. Specifically, changes in stage are muted when surface waters are hydraulically isolated from the aquifer by way of low permeability sediments. Changes in stage within channels that are not incised through low permeability sediments into the higher permeability aquifer have less effect on aquifer groundwater levels and salinity. In contrast, surface-water features that are not isolated by low permeability sediments display a more rapid and larger magnitude response on surrounding groundwater levels and salinity. The coarse-grained sand part of the Surficial aquifer can drain into surface waters if tidal influences cause surface-water levels to drop below the groundwater levels within the sand. Lower-permeability shallow sediments retain most water and remain saturated or nearly saturated. Examples of these lower permeability sediments include marsh sediments with a high fraction of organic mud and sand, as well as the underlying clayey and fine-grained sand sediments. Oscillating tidal action continually resaturates unsaturated sediments, causing subsurface mixing, resulting in water of different salinity than that of surface waters.

Sea-level rise affects processes in groundwater (saturated sediment) and the vadose zone (unsaturated soil) beneath the land surface. It causes groundwater levels to rise, which decreases the thickness of, and increases the moisture content of, unsaturated soils. The effects of tides on shallow groundwater levels increase the wetting and drying of the vadose zone and any artifacts that may be present within that zone. Such wetting and drying cycles accelerate the degradation of organic material by microorganisms. Rising groundwater levels can create standing water across the land surface in lowlying areas, decreasing shallow subsurface storage capacity and promoting further inundation by tides and storm surges (Masterson and Garabedian, 2007; Masterson and others, 2013).

As the salinity of surface waters increases, groundwater salinity typically increases (Masterson and Garabedian, 2007; Masterson and others, 2013). As in surface waters, fresh groundwater from infiltrating precipitation overlies denser saline groundwater. Beneath coastal barrier islands like nearby Assateague Island, this freshwater forms a surficial lens (Masterson and Garabedian, 2007; Masterson and others, 2013), referred to as island hydrology (fig. 10A). As sea level rises and the exposed island becomes smaller, the areal extent of the freshwater lens decreases (fig. 10B) such that the lens can disappear even before the entire island is inundated (Masterson and others, 2013).

Saline surface water flowing into and through aquifers beneath marshes and adjacent uplands can create an oxidationreduction sequence involving manganese, iron, and (or) sulfur. Saline surface water entering aquifers contains higher sulfate concentrations than freshwater and moderate-to-abundant 

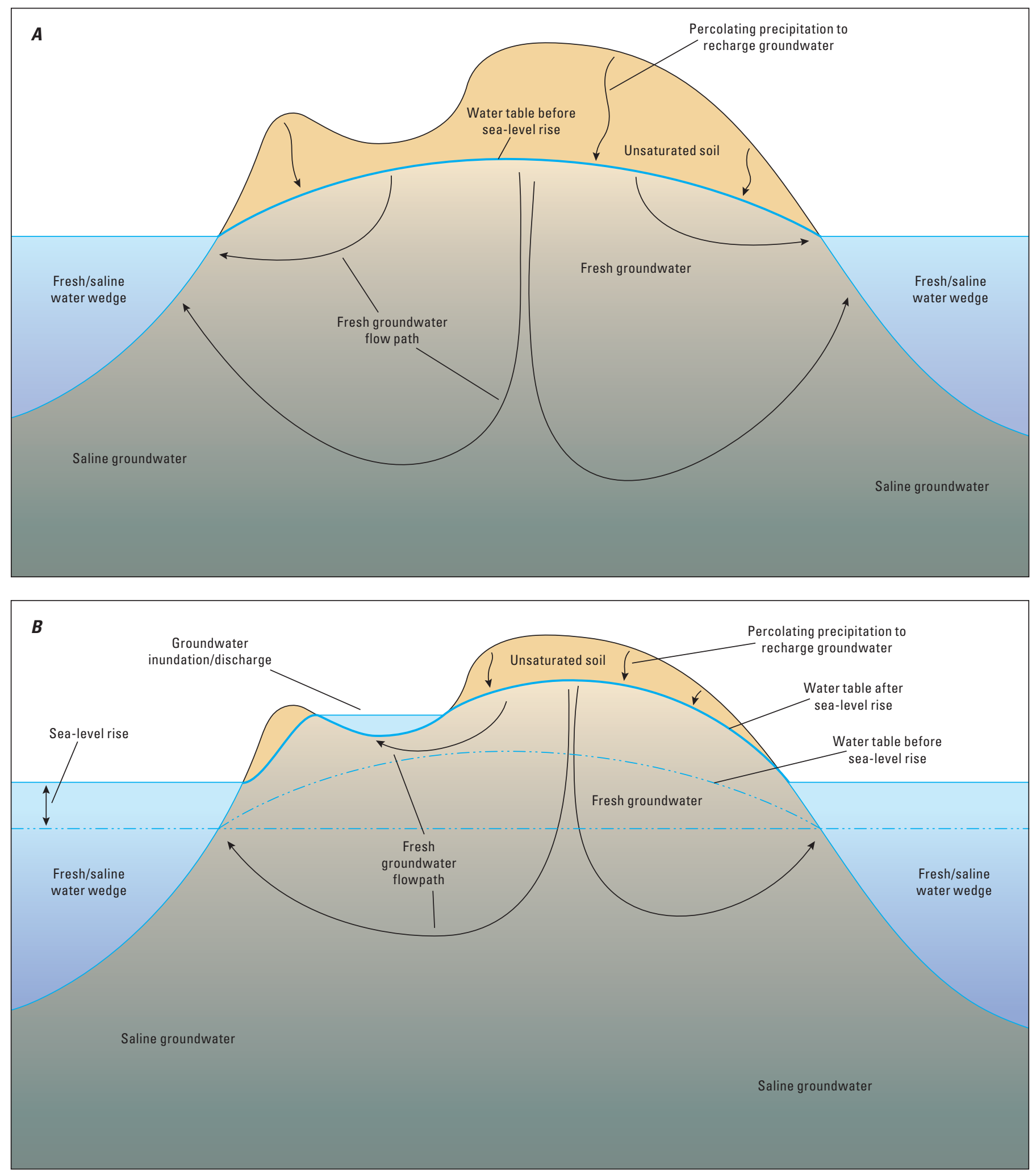

NOT TO SCALE

Figure 10. Schematic diagrams showing $A$, a freshwater lens overlying saline water beneath a coastal island and $B$, the decreasing extent of this lens and inundation of land by rising groundwater levels as sea level rises. 
concentrations of dissolved oxygen (oxic conditions). As saline groundwater flows through organic marsh sediment, microorganisms consume and deplete the dissolved oxygen through the biodegradation of organic matter, creating anoxic conditions (fig. 11). Under anoxic conditions, bacteria further biodegrade the organic matter by concomitantly reducing iron-oxide minerals in sediment. When iron-oxide minerals become depleted, sulfate in the saline water is reduced to sulfide. These reduced chemical species can combine to form sedimentary pyrite, an insoluble iron-sulfide mineral, in the sediment (Lord and Church, 1983), and possibly, in artifacts with sufficient porosity. Subsequently, if dissolved oxygen is reintroduced into the subsurface by burrowing worms and other organisms, tidal fluctuations, declining surface-water levels after storm surges, and (or) increased oxygenated freshwater recharge, the pyrite oxidizes to iron oxides and sulfate. Archaeological interpretation can be complicated by staining from oxidation-reduction reactions, such as black staining caused by the precipitation of manganese oxides and pyrite and reddish staining caused by the precipitation of iron oxides and oxyhydroxides.

Rising groundwater levels, increased groundwater salinity, and changing groundwater chemistry can stress and kill trees and other vegetation. Such effects can become an issue when the water table rises and saturates sediment surrounding the fine and small roots that take in water and nutrients (Armstrong and others, 1994). The density of fine and small roots typically is greatest near land surface and decreases with depth (fig. 12). For example, at the Great Dismal Swamp to the south of Jamestown Island, the 0 - to 0.3 -ft-depth interval contained 55 to 67 percent of the fine and small roots present in the upper $1.3 \mathrm{ft}$ of three wetland-forest-community types and 58 percent of the fine and small roots in an upland-forest community (Powell and Day, 1991). As groundwater levels rise and approach land surface, more of the soil surrounding the fine and small roots of trees and other vegetation becomes

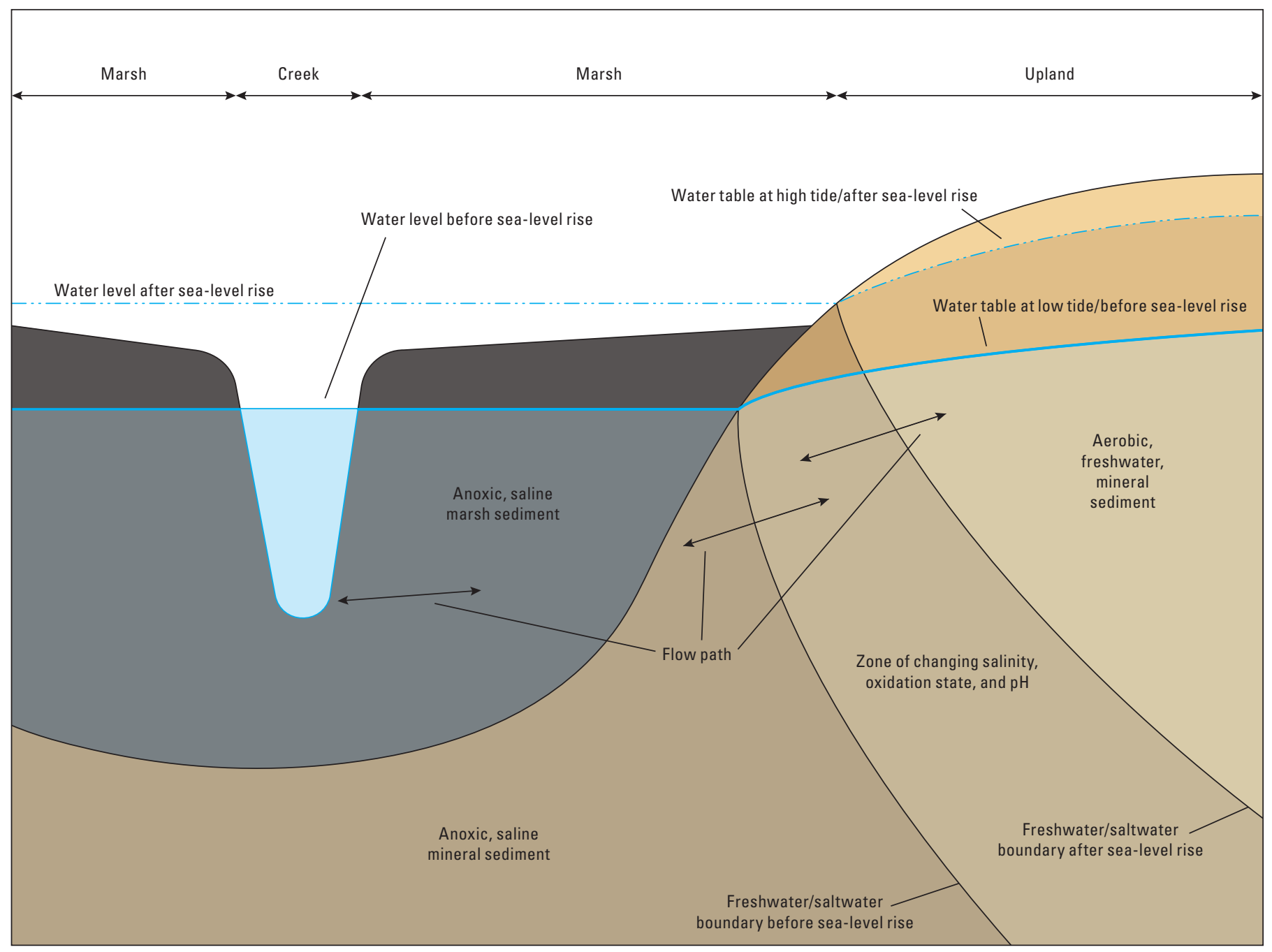

NOT TO SCALE

Figure 11. Schematic showing the zones of changing groundwater chemistry as saline groundwater becomes anoxic when flowing through organic sediment beneath marshes and becomes reoxygenated by various processes. 

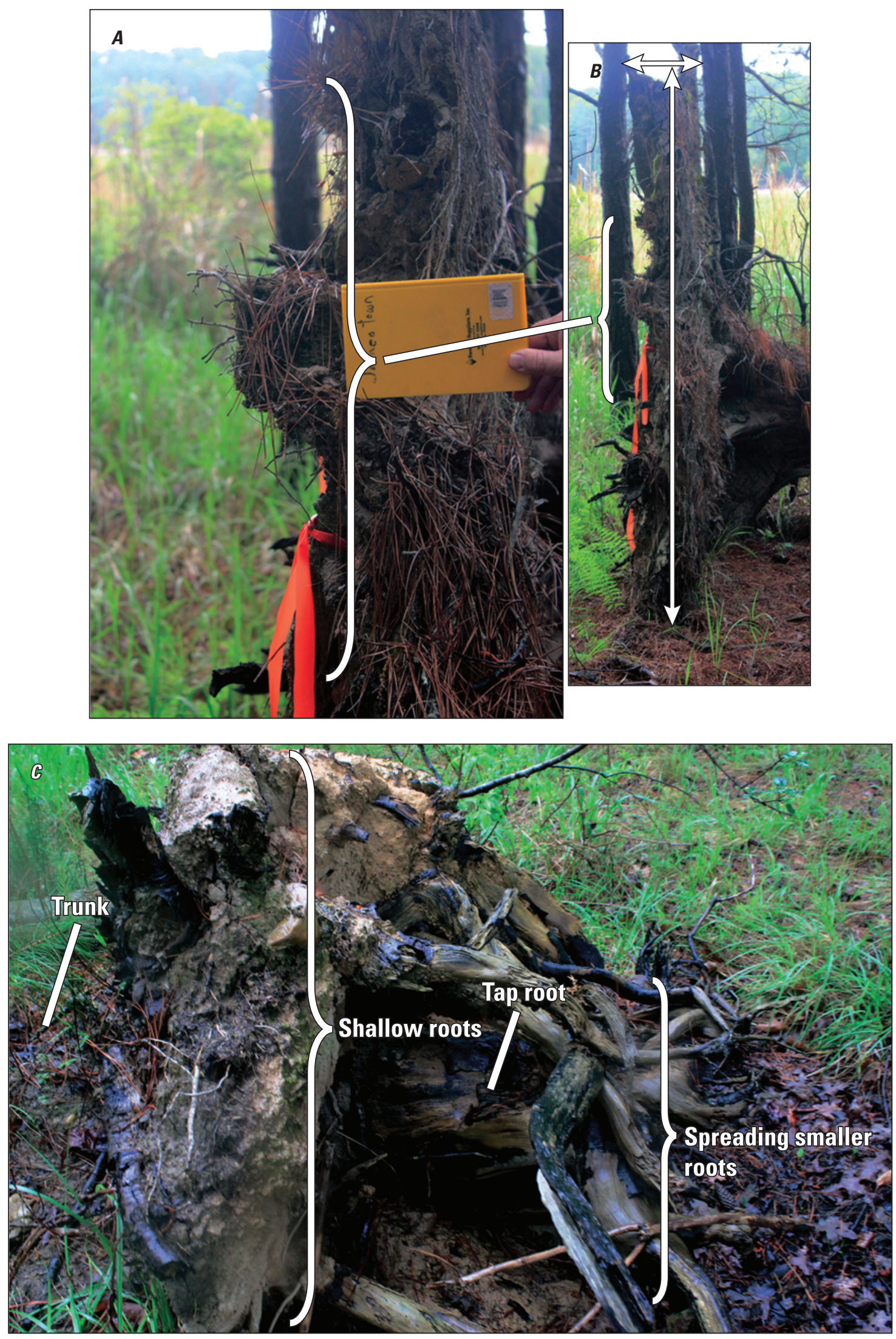

Figure 12. Photographs showing $A$, the shallow depth of roots of an uprooted deciduous tree; $B$, the wide spread of the same shallow roots; and $C$, the shallow roots and the abrupt termination of a tap root with spreading smaller roots of an uprooted pine tree, Jamestown Island, Colonial National Historical Park, Virginia. 


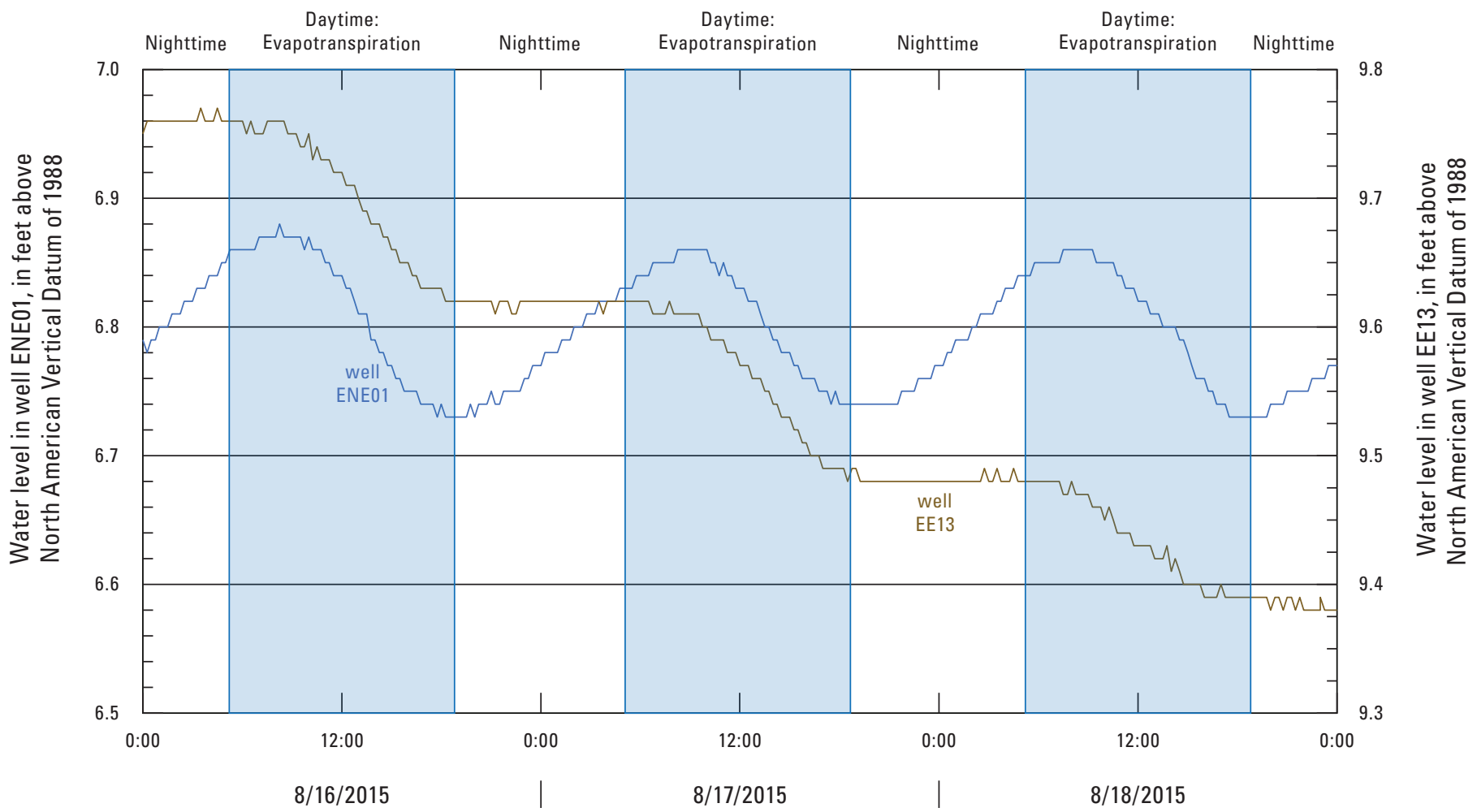

Time, in hours and minutes

Figure 13. Graph showing sinusoidal (well ENE01) and stair-step (well EE13) diurnal cycles in groundwater levels, which results from daytime evapotranspiration (modified from Speiran and Wurster, 2021).

saturated. Organic material in the soil is degraded by bacteria, causing groundwater to become anoxic, which creates conditions that stress and can kill the vegetation (Armstrong and others, 1994). Under these conditions, wetland species employ adaptations that are metabolically less efficient and typically result in less water uptake (Armstrong and others, 1994). This lower efficiency allows the trees to survive, but not necessarily thrive. Because upland species cannot adapt in such a manner, they become stressed, eventually die, and are replaced by wetland species (Armstrong and others, 1994). If the water is saline, wetland and upland species not adapted to saline conditions become stressed and die. As groundwater levels decline in wetlands from tides and other processes, more of the roots are exposed to unsaturated, oxygenated soil so that the vegetation shifts back to normal, more efficient, metabolic processes (Armstrong and others, 1994).

Unsaturated soil contains water in part of the pore space of the soil surrounding fine and small roots. This water can be derived from precipitation that infiltrates into the soil and percolates downward or can be water retained in the soil as groundwater levels decline. As vegetation transpires, the removal of the water from the soil increases negative pressure (suction) within the vadose zone. The negative pressure causes water to flow from the water table, where pressure is equal to atmospheric pressure, through unsaturated soil. The water can be intercepted by small and fine shallow roots (White,
1932) or by large deep roots by way of hydraulic redistribution to fine shallow roots and then into the soil (Dawson, 1992; Prieto and others, 2012). In shallow groundwater systems, ET can cause diurnal cycles of declining daytime groundwater levels followed by rising nighttime groundwater levels, which create a sinusoidal pattern (fig. 13) first identified by White (1932) and described in groundwater (for example, Freeze and Cherry, 1979) and wetland (for example, Mitsch and Gosselink, 2007) textbooks. Groundwater levels can decline during the daytime because of the removal of groundwater in storage by ET and rebound at night as the aquifer recovers. In aquifers with limited storage, the cycle is modified to a stair-step pattern with a rapid decline during the daytime followed by a small decline or no change during the nighttime (fig. 13). Hydraulic redistribution can cause the water level to decline during nighttime when ET is minimal (Dawson, 1992; Prieto and others, 2012). Although the uptake of groundwater was long inferred from the response of groundwater levels, Sánchez-Pérez and others (2008) used the stable isotopes of water (deuterium and oxygen-18) to demonstrate this flow and uptake of both precipitation and groundwater by trees.

At several sites in Virginia (Speiran, 1996; Speiran and Wurster, 2021), the largest decline in groundwater levels was during the daytime when ET was the greatest. Groundwater levels rose, remained unchanged, or declined slightly during the nighttime. This indicates that transport of water through 

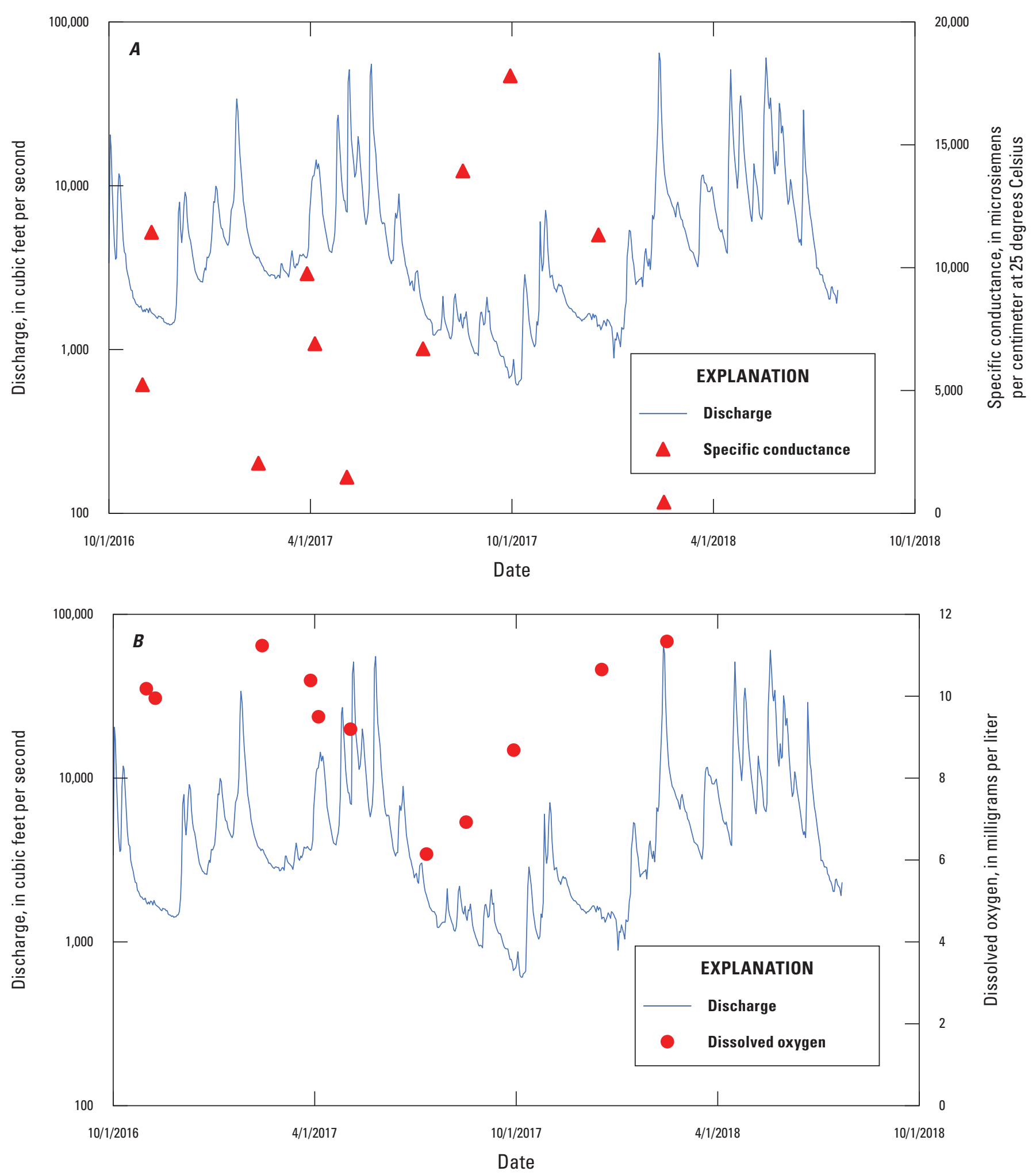

Figure 14. Graphs showing discharge of the James River near Richmond, Va. (station 02037500) from October 2016 through July 2018 as well as $A$, periodic specific conductance, and $B$, periodic dissolved oxygen of the James River at the Earthworks, Jamestown Island, Colonial National Historical Park, Virginia. 
unsaturated soil is a function of both evaporation and plant transpiration. The exposure of more fine and small roots to unsaturated soil as the water table declines during periods of little precipitation increases the amount of groundwater uptake and, consequently, the rate of water-level decline (Speiran, 1996). In tidal areas, the effects of tides can mask diurnal groundwater fluctuations caused by ET.

\section{Hydrologic and Chemical Responses of Groundwater}

Hydrologic and chemical responses of groundwater to tides, storm surges, and sea-level rise depend on the hydrologic and chemical settings across Jamestown Island. These settings can be broadly grouped on the basis of land-surface altitude of the uplands - high altitude (about 10 to $15 \mathrm{ft}$ above NAVD 88), and low altitude (about 3 to $6 \mathrm{ft}$ above NAVD 88). The Island House sites represent conditions at high-altitude uplands, which predominate at the west end of the island. The Black Point, Earthworks, and Tour Road 2 sites represent conditions at low-altitude uplands, more typical of the east end of the island. Tour Road 1 appears to be at the edge of a highaltitude upland.

From October 2016 through June 2017, James River discharge varied appreciably, making the competing effects of discharge and tides on groundwater difficult to identify with the measurement frequency (fig. 14). The large increase in the specific conductance of James River water during the summer of 2017 resulted from low discharge during that period, which was followed by decreasing specific conductance as discharge increased into the fall and winter (fig. 14A). These large responses demonstrate how discharge from the watershed controls the salinity of the James River and surrounding waters in the absence of storm surges.

Dissolved-oxygen concentrations in the James River at the Earthworks followed a seasonal pattern, with the highest concentrations in the winter, which then decreased in the summer (fig. 14B). This seasonal pattern is consistent with lower bacterial uptake of oxygen and cooler water temperatures in the winter, both of which allow for higher dissolved-oxygen concentrations.

Specific conductance of the James River at EW1 (the site with the most data) ranged from 490 to 17,800 microsiemens per centimeter ( $\mu \mathrm{S} / \mathrm{cm}$; fig. $14 A$ ), classified as fresh to saline (table 2). Specific conductance at the marsh sites and the James River at Black Point is similar to that of the river at the Earthworks except for lower specific conductance in the marsh at the Earthworks in September 2017 and the marsh at the Island House in November 2017 (fig. 15). The cause of the lower values could be dilution by precipitation, inundation during a previous high tide, or other processes. This similarity in specific conductance indicates a general uniformity in the

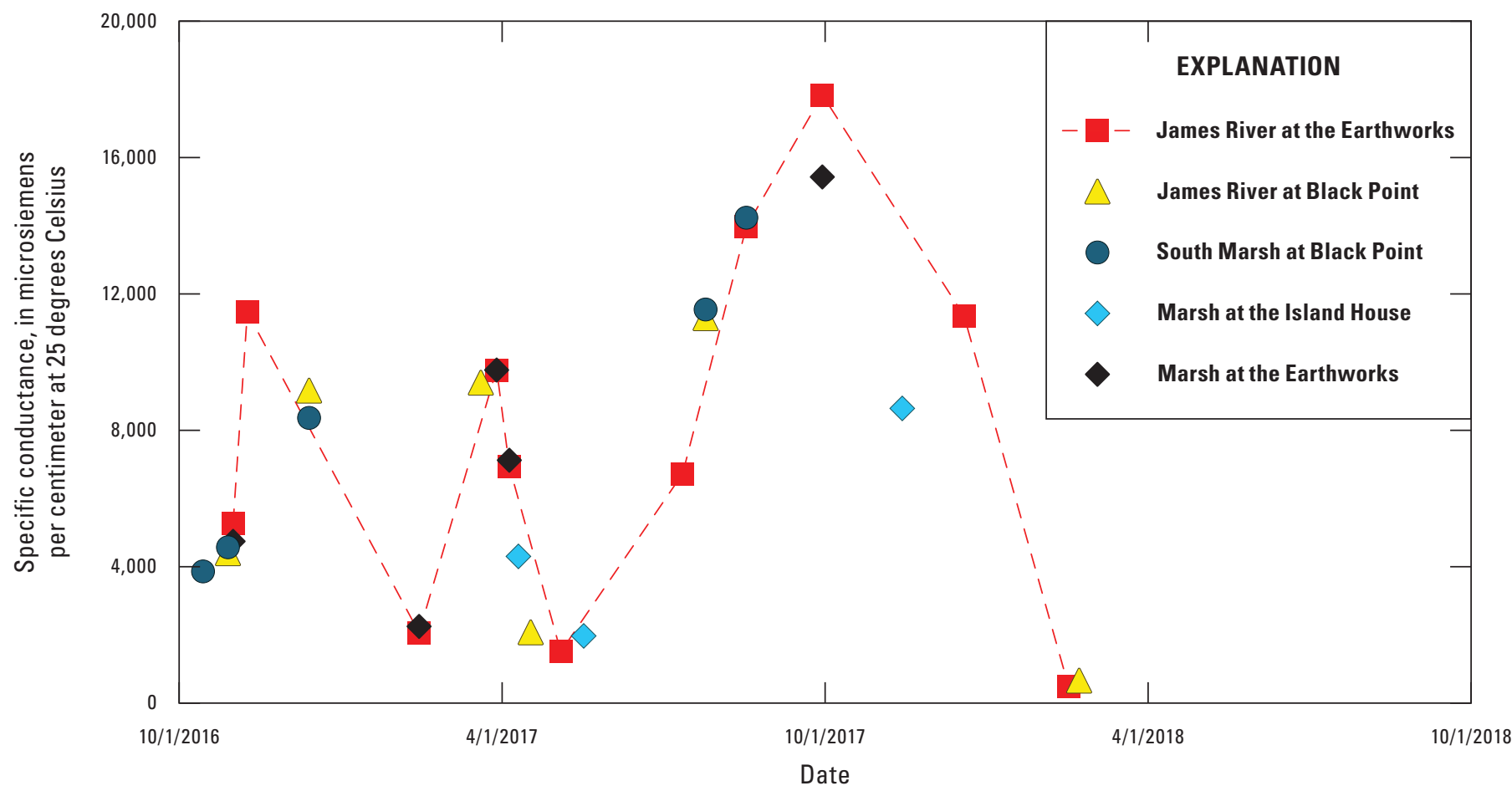

Figure 15. Graph showing the specific conductance of water from the James River at the Earthworks (EW-1), the marsh at the Island House (IH-1), the south marsh at Black Point (BP-6), the James River at Black Point, and the marsh at the Earthworks (EW-9), from October 2016 through February 2018, Jamestown Island, Colonial National Historical Park, Virginia. 


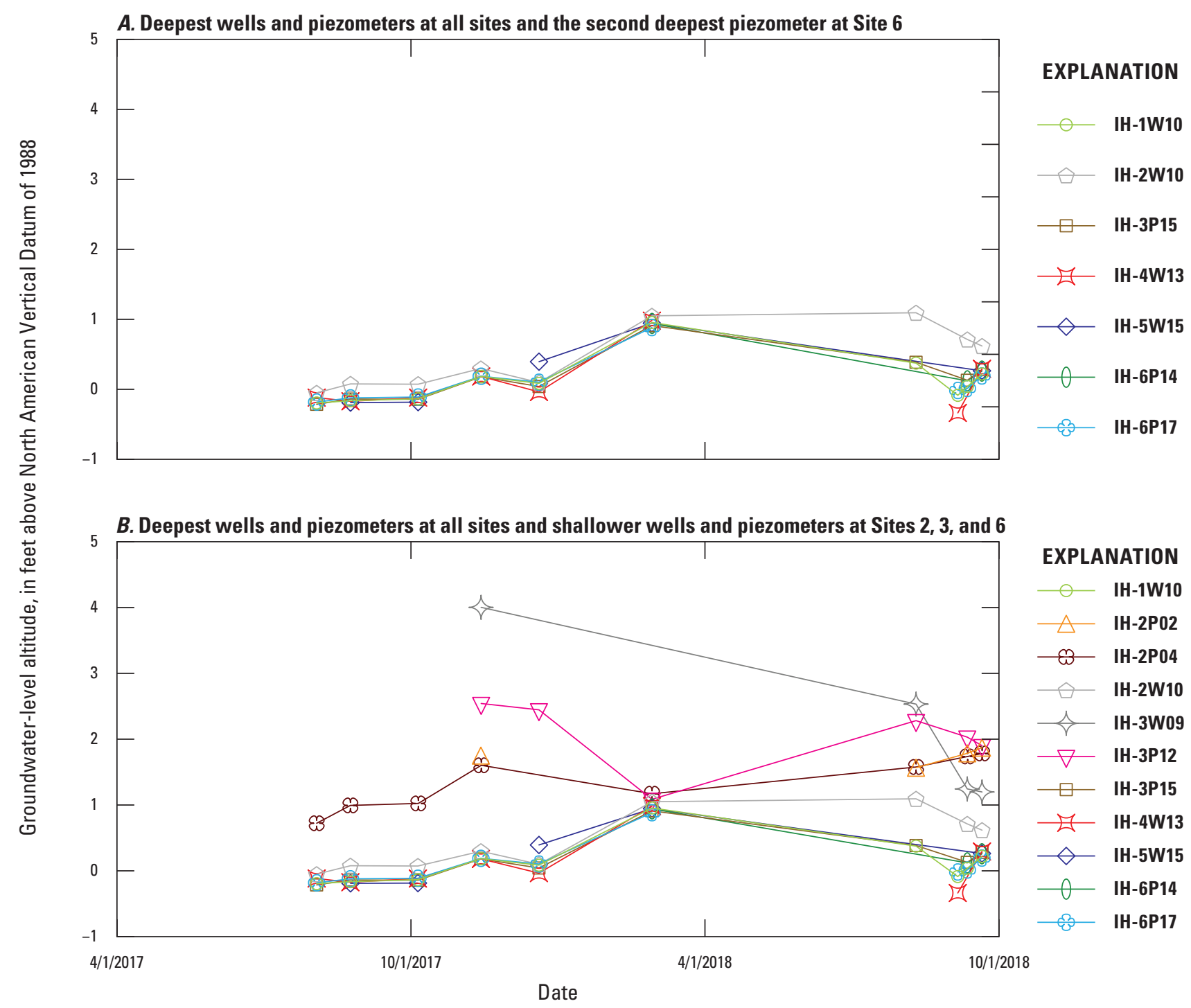

Figure 16. Graphs showing the altitude of groundwater levels in $A$, the deepest wells and piezometers at all sites and the second deepest piezometer at site 6 , and $B$, the deepest wells and piezometers at all sites and the shallower wells and piezometers at sites 2, 3, and 6 along the transect at the Island House, Jamestown Island, Colonial National Historical Park, Virginia.

salinity of the surface waters at study sites around the island. As in the James River, water at these sites was slightly to moderately saline.

\section{Island House: High-Altitude, Upland Setting}

The deepest well or piezometer at each site in the Island House transect except IH-4 was open to the coarse-grained sand (fig. 5). Groundwater levels in these wells and piezometers changed just over $1 \mathrm{ft}$ from August 3, 2017, to September 20,2018, and were at similar altitudes across the sites on most dates (fig. 16A). Water-level altitudes in the coarse-grained sand at IH-2 (the marsh/forest edge) generally were higher than at all other sites (fig. 16A).

A downward gradient was evident from the clayey sediment to the coarse-grained sand at IH-2 and IH-3 (fig. 16B), the only two sites that have piezometers open to saturated clayey sediment (fig. 5A). This downward gradient reflects recharge and downward flow. IH-6 has two piezometers open to the clayey sediment, but those sediments remained unsaturated throughout the study. Water levels in the two piezometers open to the shallow clayey sediment at IH-2 were similar to each other and higher than levels in all wells and piezometers open to the coarse-grained sand on all dates (fig. 16B). At $\mathrm{IH}-3$, water levels in the clayey sediment and upper part of the coarse-grained sand differed from each other and were higher than those in the deeper, coarse-grained sand on most dates (fig. 16B).

Dissolved-oxygen concentrations in groundwater beneath the marsh at the Island House ranged from nearly 0 to about $10 \mathrm{mg} / \mathrm{L}$ but followed no distinct pattern (fig. 17A). Dissolvedoxygen concentrations in groundwater beneath the uplands at 


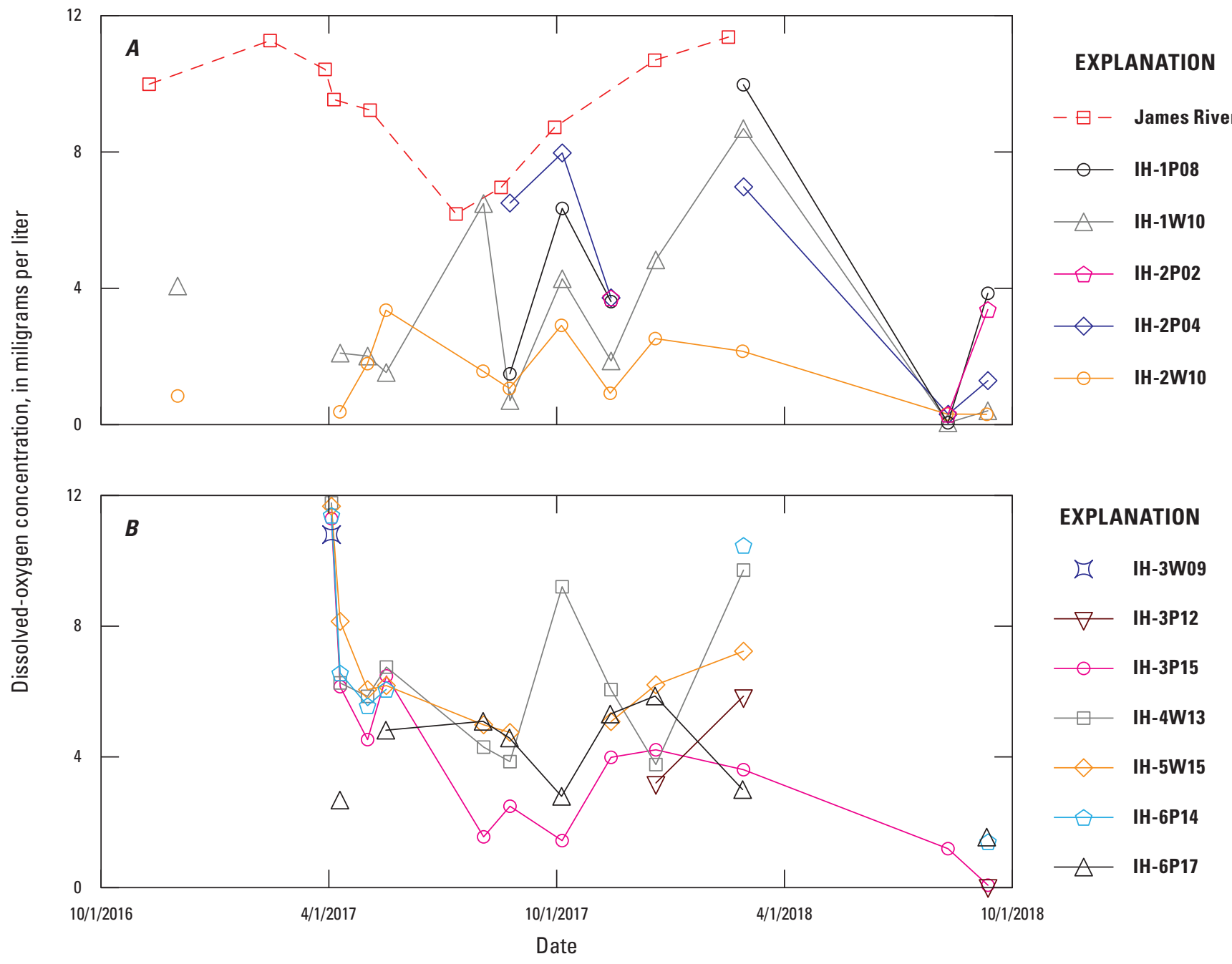

Figure 17. Graphs showing dissolved-oxygen concentrations of water from the James River at the Earthworks and of groundwater $A$, beneath the marsh $(\mathrm{IH}-1)$ and the marsh/forest edge $(\mathrm{IH}-2)$, and $B$, beneath the uplands $(\mathrm{IH}-3, \mathrm{IH}-4, \mathrm{IH}-5$, and $\mathrm{IH}-6)$ at the Island House from December 2016 through August 2018, Jamestown Island, Colonial National Historical Park, Virginia.

the Island House varied widely, with a range from nearly 0 to $12 \mathrm{mg} / \mathrm{L}$ (fig. 17B).

The specific conductance of groundwater at Island House sites differed temporally and spatially, but generally decreased from the marsh to the upland (fig. 18). Specific conductance of groundwater beneath the marsh (IH-1P08 and IH-1W10) was more stable and less responsive to changes in specific conductance of the river than groundwater at the marsh/forest edge ( $\mathrm{IH}-2 \mathrm{P} 02, \mathrm{IH}-2 \mathrm{P} 04$, and $\mathrm{IH}-2 \mathrm{~W} 10)$, although the marsh was at a lower altitude and more frequently inundated than the marsh/ forest edge (table 3). The specific conductance of groundwater beneath the marsh ranged from about 3,300 to $6,700 \mu \mathrm{S} / \mathrm{cm}$, whereas that at the marsh/forest edge ranged from about 1,800 to $8,400 \mu \mathrm{S} / \mathrm{cm}$; water at both sites was slightly to moderately saline (fig. 18A; table 2). The most rapid change in specific conductance of groundwater was in clayey sediment at the marsh/forest edge, which increased from 1,800 to $8,400 \mu \mathrm{S} / \mathrm{cm}$ in IH-2P04 from early August through October 2017, coinciding with the increased specific conductance of James River water from 1,500 to $17,800 \mu \mathrm{S} / \mathrm{cm}$ (fig. $18 A$ ). The specific conductance of groundwater from IH-2W10 changed similarly through that period. The specific conductance of groundwater at both depths then decreased more gradually than that of the river. Specific conductance responded little in IH-1P08 (4,200 to $5,900 \mu \mathrm{S} / \mathrm{cm})$ and in IH-1W10 $(4,800$ to $5,000 \mu \mathrm{S} / \mathrm{cm})$ in response to the change in the specific conductance of river water.

Specific conductance was substantially less at the upland sites (Site 3 [IH-3P12 and IH-3P15], Site 4 [IH-4W13], and Site 5 [IH-5W15]) than at the marsh/forest edge (Site 2; fig. $18 B$ ). The specific conductance of groundwater ranged from 87 to $163 \mu \mathrm{S} / \mathrm{cm}$ at Sites 4 and 5 (fig. 18C) and is considered fresh (table 2), as is typical for groundwater recharged by precipitation in noncarbonate unconsolidated sedimentary aquifers.

The specific conductance of groundwater beneath Site 3 responded differently to changes in river salinity than any other upland site or sites near and in the marsh. Although the 


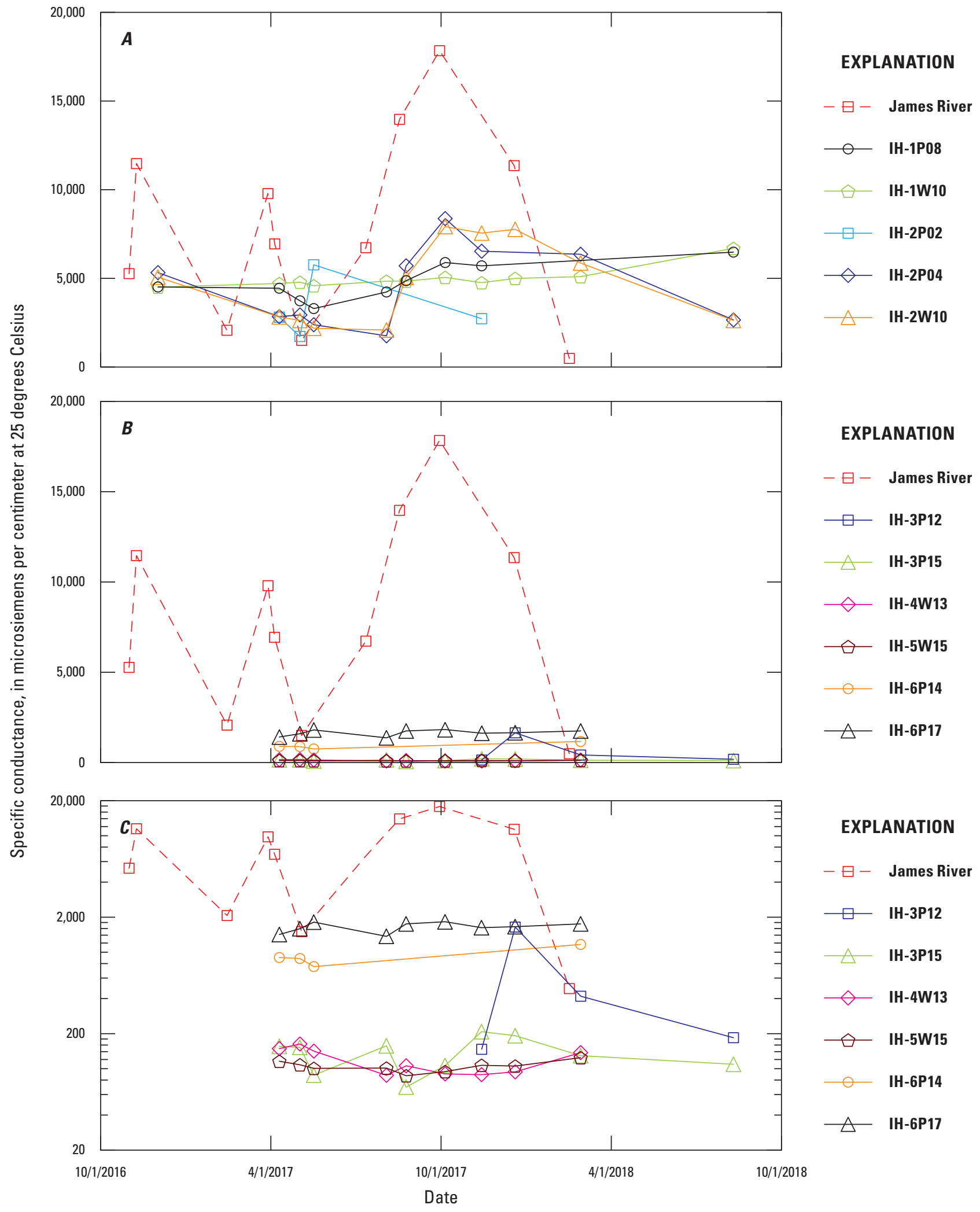

Figure 18. Graphs showing the specific conductance of water from the James River at the Earthworks and of groundwater $A$, beneath the marsh $(\mathrm{IH}-1)$ and the marsh/forest edge $(\mathrm{IH}-2)$ on an arithmetic scale; $B$, beneath the uplands $(\mathrm{IH}-3, \mathrm{IH}-4, \mathrm{IH}-5$, and $\mathrm{IH}-6)$ on an arithmetic scale; and $C$, beneath the uplands ( $\mathrm{IH}-3, \mathrm{IH}-4, \mathrm{IH}-5$, and $\mathrm{IH}-6)$ on a logarithmic scale at the Island House from December 2016 through August 2018, Jamestown Island, Colonial National Historical Park, Virginia. 
water remained fresh, the specific conductance of groundwater from IH-3P15 appeared to increase in a delayed and attenuated pattern from that of the river, increasing from 69 to $208 \mu \mathrm{S} / \mathrm{cm}$ before gradually decreasing (fig. 18C). The specific conductance of groundwater from $\mathrm{IH}-3 \mathrm{P} 12$, the shallower piezometer, responded in a delayed but less attenuated pattern, increasing from 147 to $1,650 \mu \mathrm{S} / \mathrm{cm}$ in December 2017 (fig. 18C), although it remained within the freshwater classification (table 2). The specific conductance of groundwater from IH-3P12 remained greater than that of IH-3P15 through August 2018.

Site 6 (IH-6P1, IH-6P5, IH-6P9, IH-6P14, and IH-6P17) was at the highest altitude along the transect (fig. $5 \mathrm{~A}$ ) and near the midpoint and highest-altitude point of the ridge. The specific conductance of groundwater from both IH-6P14 and IH-6P17 was relatively stable, but greater than that of groundwater at Sites 4 and 5, and less than that of groundwater beneath the marsh and the marsh/forest edge (fig. 18B). Only the two deepest piezometers at Site 6 contained water during the monitoring period so that levels and quality could be measured. Piezometer IH-6P14 was dry from June 2017 until February 2018. The specific conductance of groundwater from IH-6P14 ranged from 750 to $1,170 \mu \mathrm{S} / \mathrm{cm}$ (fresh), and in IH-6P17 it ranged from 1,370 to $1,830 \mu \mathrm{S} / \mathrm{cm}$ (fresh to slightly saline; fig. 18C). Unlike at Site 3, the specific conductance of groundwater was lower at the shallower depth at Site 6 .

The specific conductance of groundwater at the Island House was not consistent across the upland (fig. 18B, C). Although IH-2 is in the forest at the marsh/forest edge, groundwater was slightly to moderately saline and varied more than in IH-1 beneath the marsh (fig. 18A). The land surface at IH-2 is $2.76 \mathrm{ft}$ above NAVD 88 , consequently, the well was inundated during the daily highest high tides on only about 4 percent of the days (about 15 days per year) for the period of record for the Jamestown Ferry Pier tide station (fig. 8 ; table 3). The land surface within 2-3 ft of $\mathrm{IH}-2$, however, is $0.5-1.0 \mathrm{ft}$ lower, therefore, it was inundated more frequently. As an example, no standing water was present near the site or in the nearby marsh at the beginning of the day of well and piezometer installation. Before construction was completed that day, no standing water was at the immediate site, but the low ground surrounding the site became inundated by surface water as the tide rose. The root hole of a nearby fallen tree filled with discharging groundwater as the tide rose. The low-permeability organic mud and sand beneath the marsh and the upper clay of the Tabb Formation present at higher altitude upland sites (fig. 5) are absent at IH-2, although the lower clayey silt is present. This creates a higher-permeability surficial sediment for greater infiltration, recharge, and flow of fresh and saline water at this site compared to the marsh site and the higher-altitude uplands. The higher water levels at IH-2 than other sites at the Island House and the downward vertical water-level gradient (fig. 16) indicate recharge at this site and flow from the marsh/forest edge toward both the marsh and the upland ridge. Flow typically is from the upland ridge to the marsh/forest edge and to the marsh at such sites. Fresh groundwater recharged through the uplands mixes
Table 3. Percent of days and average number of days per year that well or piezometer sites were inundated during high tide for the period August 13, 2015, through February 20, 2018, Jamestown Island, Colonial National Historical Park, Virginia.

\begin{tabular}{|c|c|c|c|}
\hline Site & $\begin{array}{c}\text { Average } \\
\text { land- surface } \\
\text { elevation, in } \\
\text { feet above } \\
\text { National } \\
\text { Vertical Datum } \\
\text { of } 1988\end{array}$ & $\begin{array}{l}\text { Percent } \\
\text { of days } \\
\text { inundated on } \\
\text { high tide }\end{array}$ & $\begin{array}{c}\text { Average } \\
\text { number of } \\
\text { days per year } \\
\text { inundated on } \\
\text { high tide }\end{array}$ \\
\hline \multicolumn{4}{|c|}{ Island House } \\
\hline IH-1 & 1.11 & 79 & 288 \\
\hline IH-2 & 2.76 & 4 & 15 \\
\hline IH-3 & 7.98 & 0 & 0 \\
\hline $\mathrm{IH}-4$ & 10.12 & 0 & 0 \\
\hline IH-5 & 11.30 & 0 & 0 \\
\hline IH-6 & 12.84 & 0 & 0 \\
\hline \multicolumn{4}{|c|}{ Black Point } \\
\hline BP-1 & 1.70 & 41 & 150 \\
\hline BP-2 & 2.26 & 13.1 & 48 \\
\hline BP-3 & 3.75 & 0.6 & 2 \\
\hline BP-4 & 3.16 & 1.9 & 7 \\
\hline BP-5 & 1.53 & 53 & 193 \\
\hline BP-6 & 0.88 & 89 & 325 \\
\hline \multicolumn{4}{|c|}{ Earthworks } \\
\hline EW-1 & 1.23 & 74 & 270 \\
\hline EW-2 & 3.30 & 1.0 & 4 \\
\hline EW-3 & 3.72 & 0.8 & 2 \\
\hline EW-4 & 4.42 & 0.2 & $<1$ \\
\hline EW-8 & 1.37 & 65 & 237 \\
\hline EW-9 & 0.85 & 89 & 325 \\
\hline \multicolumn{4}{|c|}{ Tour Road 1} \\
\hline TR-1 & 4.64 & 0.2 & $<1$ \\
\hline \multicolumn{4}{|c|}{ Tour Road 2} \\
\hline TR-2 & 4.22 & 0.5 & 2 \\
\hline
\end{tabular}

with saline water from the marsh. Although the land-surface altitude at IH-2 is higher than that of the marsh, and recharge from precipitation is likely, no freshwater was observed at the water table at IH-2 (fig. 18A).

The specific conductance of groundwater at $\mathrm{IH}-3$ responded to the increased salinity of the river differently between the two piezometers and from the response at IH-2. The specific conductance of groundwater from IH-3P15 mimicked river patterns but was delayed, attenuated, and fresh $(69-210 \mu \mathrm{S} / \mathrm{cm})$. In the slightly shallower piezometer, $\mathrm{IH}-3 \mathrm{P} 12$, the change in groundwater specific conductance of $140-1,600 \mu \mathrm{S} / \mathrm{cm}$ was delayed by several months. This 


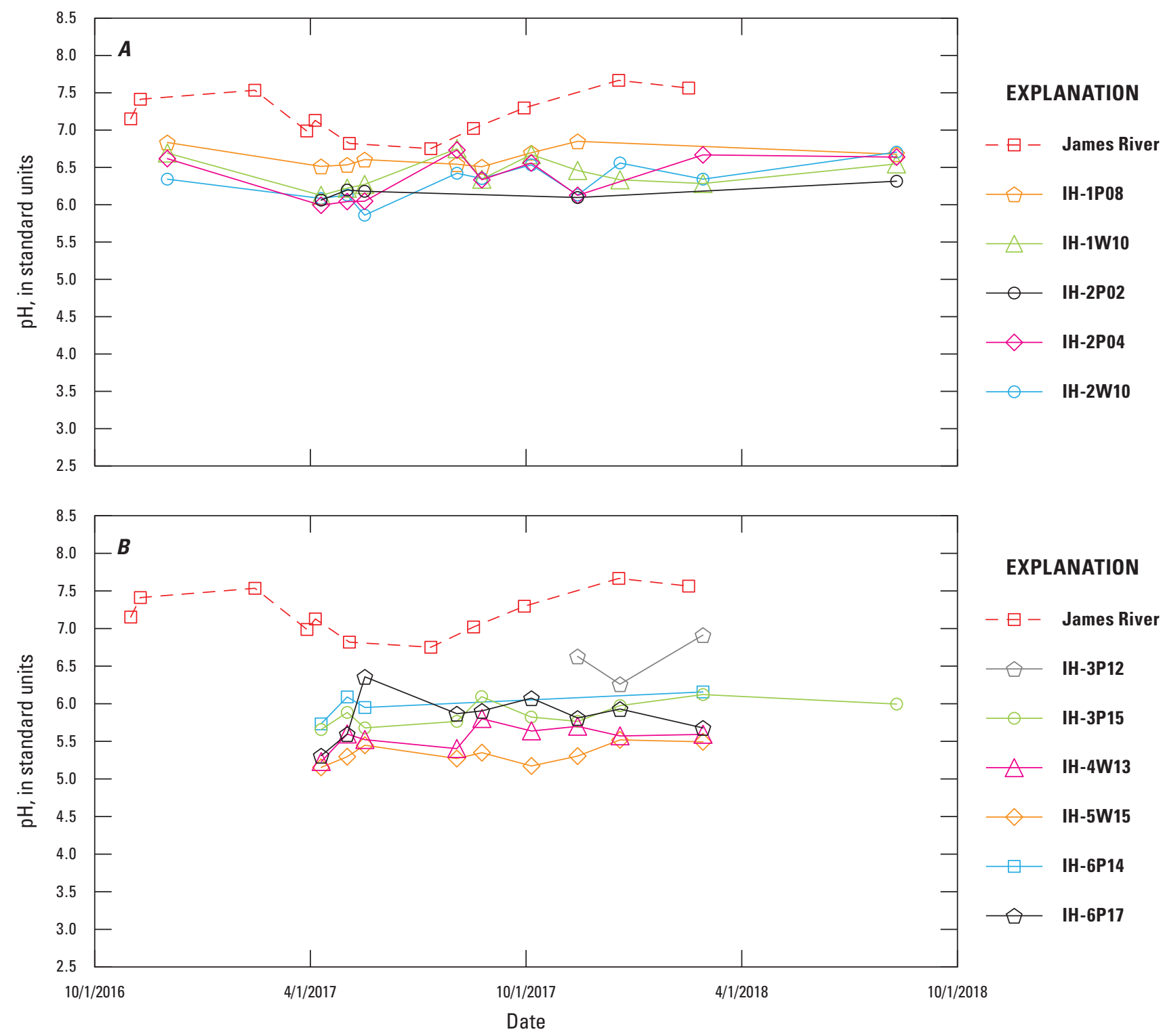

Figure 19. Graphs showing the $\mathrm{pH}$ of water from the James River at the Earthworks and of groundwater $A$, beneath the marsh (IH-1) and the marsh/forest edge (IH-2); and $B$, beneath the uplands (IH-3, IH-4, IH-5, and $\mathrm{IH}-6)$ at the Island House from December 2016 through August 2018, Jamestown Island, Colonial National Historical Park, Virginia.

response appears to indicate greater horizontal than vertical hydraulic conductivity, typical in noncarbonate sedimentary aquifers (Freeze and Cherry, 1979). This caused the slightly more saline water to flow laterally through the shallower part of the aquifer, creating a density inversion. The effects of the lower vertical permeability are indicated by the higher vertical water-level gradient in the upper sediment at IH-3 than at IH-2 (fig. 16). The specific conductance of groundwater at sites IH-4 and IH-5 remained less than $200 \mu \mathrm{S} / \mathrm{cm}$ throughout the study, which indicated the control by freshwater recharge through minimally calcareous, mineral sediment. The elevated specific conductance of groundwater from the two piezometers at $\mathrm{IH}-6$, near the ridge, does not appear to respond to changes in salinity of the river but might be diluted saline water from a previous tidal surge. The persistence of higher salinity at IH-6 than elsewhere beneath the upland could result from this part of the aquifer being near the groundwater divide where fresh groundwater flow to flush saline groundwater is limited. The flushing could be further limited because of the small amount of recharge at this site compared to other upland sites as a result of the increased clay content in the surficial sediment near the land surface typical at higher altitudes (IH-6) than at lower altitudes.

The $\mathrm{pH}$ of groundwater at the Island House varied temporally and spatially. At all Island House sites, the $\mathrm{pH}$ of groundwater was less than that of the James River but was greater than 5.0 (fig. 19). The $\mathrm{pH}$ of groundwater generally was higher beneath the marsh (6.1 to 6.8) and was lower across the 


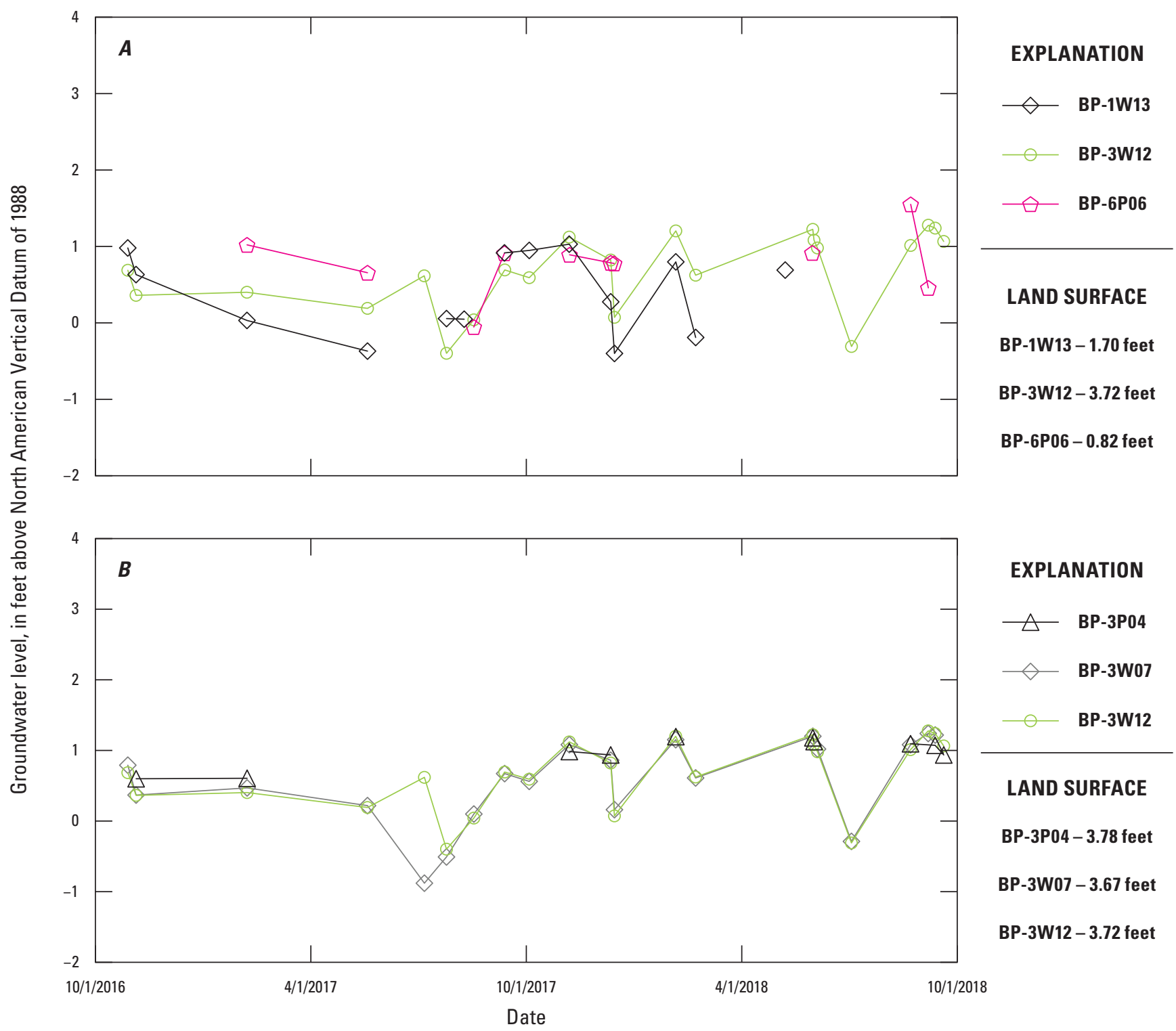

Figure 20. Graphs showing groundwater-level altitudes in $A$, the deepest wells open to the coarse-grained sand beneath the northern marsh (BP-1W13), the uplands (BP-3W12), and the southern marsh (BP-6W06); and B, wells open to different depths and sediment types beneath the uplands (BP-3) at Black Point, October 2016 to October 2018, Jamestown Island, Colonial National Historical Park, Virginia.

upland. The $\mathrm{pH}$ was higher at IH-6 (5.3 to 6.2) than upland sites IH-4 and IH-5 (5.2 to 5.8; fig. 19B). These $\mathrm{pH}$ values are consistent with natural marsh porewater-chemistry (Craft and others, 1991).

\section{Black Point: Low-Altitude, Upland Setting}

Groundwater levels in the coarse-grained sand at Black Point varied similarly beneath the uplands (BP-3), southern marsh (BP-6), and northern marsh (BP-1), with no distinct seasonal pattern from October 1, 2016, to October 1, 2018 (fig. $20 A$ ). Levels in the coarse-grained sand ranged from -0.40 to $1.55 \mathrm{ft}$ (1.95-ft range) above NAVD 88 along the transect. The levels changed over a range of $1.68 \mathrm{ft}$ beneath the uplands
(BP-3W12), $1.61 \mathrm{ft}$ beneath the southern marsh (BP-6W06), and $1.43 \mathrm{ft}$ beneath the northern marsh (BP-1W13). The depth to groundwater in the coarse-grained sand ranged from -2.44 to $-4.12 \mathrm{ft}$ beneath the uplands, -0.77 to $0.73 \mathrm{ft}$ beneath the southern marsh, and -0.58 to $-1.74 \mathrm{ft}$ beneath the northern marsh. The direction of the horizontal hydraulic gradient varied from being from the uplands to both marshes, from one marsh beneath the uplands to the other marsh, and from both marshes to the uplands (fig. 20A).

Changes in specific conductance across Black Point depended on site locations and the depth interval to which each well or piezometer was open (fig. 21). The magnitude and timing of the response of the specific conductance of groundwater to changes in salinity of the river differed among 


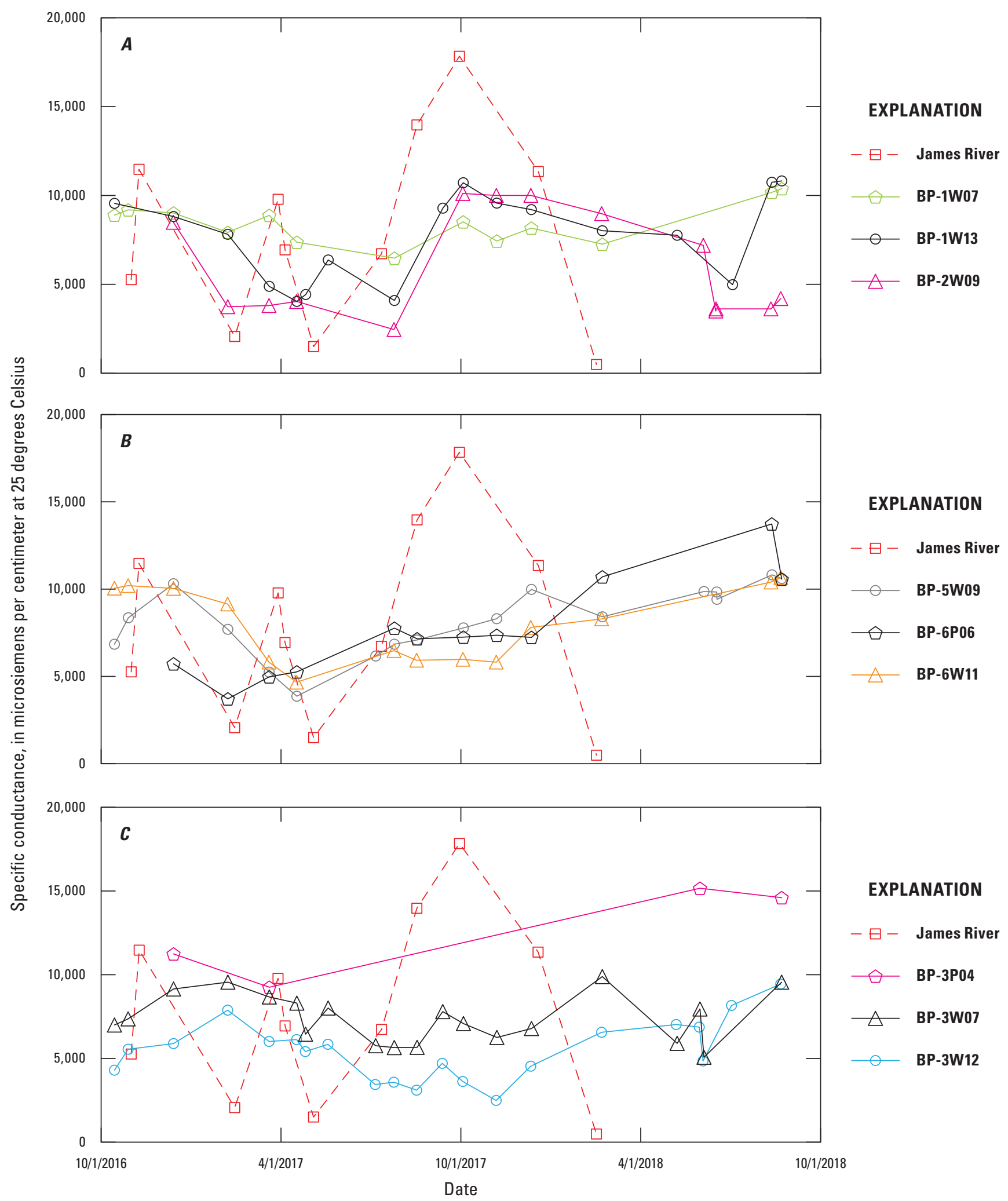

Figure 21. Graphs showing the specific conductance of water from the James River at the Earthworks and of groundwater from wells and piezometers beneath $A$, the northern marsh (BP-1W07, and BP-1W13) and the northern marsh/forest edge (BP-2W09), $B$, the southern marsh (BP-6P06 and BP-6W11) and the southern marsh/forest edge (BP5-W09), and $C$, the center of the uplands (BP-3P04, BP-3W07, and BP-3W12) at Black Point, October 2016 to October 2018, Jamestown Island, Colonial National Historical Park, Virginia. 
the northern marsh (BP-1, fig. 21A), the southern marsh (BP-6, fig. $21 B$ ), and the uplands (BP-3, fig. 21C). The response to changing river salinity was greatest and most rapid beneath the northern marsh (BP-1, fig. 21A). At BP-1, the response of specific conductance to the changing salinity of the river was larger in groundwater from the deeper well (BP-1W13), which ranged from about 4,000 to $10,800 \mu \mathrm{S} / \mathrm{cm}$, than in the shallow well (BP-1W07), which ranged from about 6,500 to 10,400 $\mu \mathrm{S} / \mathrm{cm}$ (fig. 21A). The specific conductance of groundwater from well BP2W09 at the northern marsh/forest edge ranged from about 2,500 to $10,100 \mu \mathrm{S} / \mathrm{cm}$, slightly to moderately saline (table 2), and responded in a pattern similar to that of BP-1W13 (fig. 21A).

The specific conductance of groundwater beneath the southern marsh and the southern marsh/forest edge (fig. 21B) differed from that beneath the northern marsh (fig. 21A) primarily in the timing of the response to changing river salinity, and less in the magnitude of the response. Specific conductance ranged from 4,700 to $10,700 \mu \mathrm{S} / \mathrm{cm}$ in groundwater from the deeper well beneath the southern marsh (BP-6W11) and from 3,900 to $10,800 \mu \mathrm{S} / \mathrm{cm}$ in BP-5W10 at the southern $\mathrm{marsh} /$ forest edge. Like that of the deeper well open to the same zone beneath the northern marsh (BP-1W13), both were slightly to moderately saline (table 2 ). The specific conductance of groundwater from BP-6W11 and BP-5W10 decreased from more than $10,000 \mu \mathrm{S} / \mathrm{cm}$ in December 2016 to 4,700 and 3,900 $\mathrm{S} / \mathrm{cm}$ in April 2017, respectively. It then gradually increased through August 2018 to more than 10,600 $\mu \mathrm{S} / \mathrm{cm}$ in groundwater from both wells. The specific conductance of groundwater from BP-6P06 increased rather uniformly from $3,700 \mu \mathrm{S} / \mathrm{cm}$ in February 2017 to $13,700 \mu \mathrm{S} / \mathrm{cm}$ in August 2018. Although these two wells and one piezometer are open to the coarse-grained sand, like BP-1W13 and BP-2W09 at the northern marsh, neither responded as sharply to the increased salinity in the river as those in the northern marsh.

The specific conductance of groundwater beneath the upland at Black Point ranged from 2,500 to $9,400 \mu \mathrm{S} / \mathrm{cm}$ in BP-3W12, slightly to moderately saline (table 2), and from 5,600 to $9,900 \mu \mathrm{S} / \mathrm{cm}$ in BP-3W07, moderately saline (table 2 ). The highest specific conductance of groundwater at any site at Black Point was in BP-3W04 (fig. 21C), which ranged from 9,300 to $15,200 \mu \mathrm{S} / \mathrm{cm}$, moderately saline (table 2 ). Because of the limited number of groundwater measurements from BP-3W04, no distinct patterns could be identified except that specific conductance increased during the study.

The response of specific conductance beneath the upland appeared to be delayed and of lower magnitude relative to changes in salinity of the river (fig. 21C), unlike wells in the northern marsh (fig. 21A). Changes in specific conductance were more gradual and steadier than those in the northern marsh and included an initial decrease followed by an increase, but the vertical distribution in salinity displayed a clear and persistent pattern. Specific conductance was greater in BP-3W07 (the shallower well open to the fine-grained sand) than in BP-3W12 (open to the underlying coarse-grained sand) on 19 of the 20 sampled dates. Enough water was in
BP-3W04 (open to the overlying clayey sediment) to measure specific conductance on only four of those dates; the specific conductance of groundwater from BP-3W04 ranged from 9,300 to $15,200 \mu \mathrm{S} / \mathrm{cm}$, moderately saline (table 2 ), and was greater than that from the deeper well (BP-3W07) on all four dates. The lowest specific conductance of groundwater from the shallowest well interval was similar to the highest values for the two deeper intervals. Consequently, there was a density inversion at this site, with the greatest salinity water at the water table.

The combination of low land-surface altitude, tides and storm surges, low sediment permeability, and limited discharge appears to control the salinity of groundwater beneath the low-altitude upland at Black Point. The large and rapid response of groundwater from well BP-1W13 to changes in salinity of the river (fig. 21A) was because this well is open to permeable, coarse-grained sand and gravel (fig. $5 B$ ). The response in groundwater from BP-1W07 was more gradual than that in the river and BP-1W13 because of the damping effects of flow through the less permeable fine- to mediumgrained sand to which BP-1W07 was open. Because of differences in the response between the shallower and deeper wells, specific conductance switched from being similar in both wells, to higher in the shallower well, to higher in the deeper well. Although this relation might indicate that density controls the vertical salinity distribution part of the time, the density inversion from February to September 2017 indicates the importance of sediment permeability in slowing flow and controlling the vertical salinity distribution within the aquifer at this site.

The land-surface altitude at BP- 1 is $1.7 \mathrm{ft}$ above NAVD 88 and the site was inundated about 41 percent (150 days per year) of the days during the study (fig. 8; table 3); in contrast, BP-6 is $0.88 \mathrm{ft}$ above NAVD 88 and this site was inundated about 89 percent ( 325 days per year) of the days (fig. 8; table 3 ). Consequently, the shallow sediment is saturated more of the time beneath the southern marsh than the northern marsh.

The land-surface altitude at BP-3 at the center of the ridge is $3.76 \mathrm{ft}$ above NAVD 88 and the site was inundated on average 0.6 percent (average 2 days per year) of the days during the period of record for the Jamestown Ferry Pier tide station. Inundations occurred at high tides during storm surges October 2-5, 2015 (Hurricane Juan), September 3, 2016 (Hurricane Hermine), and October 9, 2016 (Hurricane Matthew), which occurred before the start of collection of water-quality data. On October 3, 2015, the ridge remained inundated much of the day with the daily highest high tide $5.16 \mathrm{ft}$ above NAVD 88 and the daily lowest low tide $3.30 \mathrm{ft}$ above NAVD 88 .

The specific conductance of groundwater beneath the ridge at Black Point reflected a density inversion and an absence of freshwater at the water table throughout the study. The presence of the most saline water at the water table rather than deeper in the aquifer, also observed at TR-2, is atypical of coastal islands. Because the specific conductance of groundwater did not respond rapidly to the changing salinity of the river (fig. $21 \mathrm{C}$ ) and the vertical salinity distribution 
is not density controlled, lateral flow might not be the main cause of the density inversion. The changing direction of lateral hydraulic gradients (fig. 20) further indicates that the net lateral flow of groundwater could be slow. Part of the shallow, saline water might have been from recharge by saline water when the upland was inundated by storm surges. Such water would have been more saline than groundwater already in the aquifer or that had entered the aquifer by lateral flow since that time because the greatest salinity typically accompanies storm surges. The low permeability of the shallow sediment can reduce vertical mixing caused by density as indicated by data at the Island House. Vertical mixing could be further inhibited because horizontal hydraulic conductivity typically is several orders of magnitude greater than vertical hydraulic conductivity in unconsolidated sedimentary aquifers (Freeze and Cherry, 1979).

If saline water recharges groundwater, however, the question remains why freshwater from precipitation recharge is not present at the water table, at least seasonally. Recharge might flow laterally over the short distance across the dense saline water beneath the upland and discharge to the marshes. Masterson and others (2013) indicate that the decreased recharge area, as more of the land surface becomes inundated from sealevel rise, becomes insufficient to maintain the freshwater lens beneath a barrier island.

The $\mathrm{pH}$ of groundwater beneath Black Point depended on the location of the site in the transect. Beneath the northern marsh (BP-1), the $\mathrm{pH}$ of groundwater ranged from 4.3 to 6.2 , and at the marsh/forest edge (BP-2) it ranged from 3.9 to 6.3 (fig. 22A). The $\mathrm{pH}$ of groundwater was highest beneath and adjacent to the southern marsh, where it ranged from 6.4 to 8.2 beneath the marsh (BP-6). At the marsh/forest edge (BP-5), $\mathrm{pH}$ ranged from 6.0 to 7.1 and was similar to that of the river (fig. 22B). In contrast, the $\mathrm{pH}$ of groundwater beneath the upland (BP-3) was acidic, ranging from 3.6 to 4.5 in BP-3W04, 3.0 to 5.0 in BP-3W07, and 3.4 to 6.6 in BP-3W12 (fig. $22 C$ ). The $\mathrm{pH}$ beneath the uplands remained less than that beneath the marsh sites except for well BP-3W12 in July 2018 (fig. 22C).

\section{Comparison of Island House and Black Point Settings}

The response of the specific conductance and $\mathrm{pH}$ of groundwater beneath the uplands of the Island House (figs. $18 B, 19 B$ ) differs from the response beneath the uplands of Black Point (figs. 21C, 22C) because of differences in land-surface altitude, the clay content of the upper sediment, and possibly the width of Church Point ridge. Land-surface altitude affects the frequency of site inundation by high tides and storm surges (fig. 8; table 3). The ridge at Black Point was inundated by the greater than $5 \mathrm{ft}$ storm surge in October 2015, whereas the ridge at the Island House was not. At Black Point, the upper silty, sandy clay is absent, and the underlying sandy, clayey silt is thin because of the low land-surface altitude.
The narrow width of the ridge reduces the area recharged by precipitation. In contrast, the ridge at the Island House is wider, and the thickness of the upper clay and silt is greater. The response of sites to the increase in specific conductance of the James River appears to reflect the combined effects of these controls.

Differences in controls at the Black Point marsh sites make the response of groundwater beneath the southern marsh (fig. 21B) more attenuated than beneath the northern marsh (fig. $21 A$ ) but less attenuated than beneath the marsh at the Island House (fig. 18A). The characteristics of these connections are reflected in the more stable water levels at Island House (fig. 16) compared to Black Point (fig. 20).

The different responses to changing river salinity beneath the northern (BP-1, fig. 21A) and southern (BP-6, fig. 21B) marshes at Black Point are consistent with factors affecting the response at the Island House (fig. 18A). BP-1 is closer to the James River than is BP-6, and the creek that drains the northern marsh is larger and more deeply incised than the creek that drains the southern marsh. The more deeply incised channel likely enhances surface water/groundwater exchange beneath the northern marsh, as the channel is not isolated by lower permeability sediments as is the case in the southern marsh. This hypothesis would account for the more rapid response beneath the northern marsh. The creek in the southern marsh, however, is closer to BP-6 than the creek at the Island House is to IH-1. Additionally, the low-permeability marsh and clayey sediment was removed from the south side of the southern marsh to construct the Earthworks. The removal of this low permeability sediment creates the opportunity for surface water/ groundwater exchange at EW-9 but is likely sufficiently far from BP-6 to attenuate the response.

Differences in the response of groundwater beneath the marsh and marsh/forest edge of various marshes to changing river salinity reflect differences in the rates and magnitudes of surface water/groundwater exchange. The specific conductance of groundwater beneath the marsh at the Island House (IH-1, fig. 18A) was more stable than that beneath the northern (BP-1) and southern (BP-6) marshes at Black Point (fig. 21) and the marsh at the Earthworks (EW-9). The land surface across the wide marsh at the Island House is flat; the altitude at IH-1 is only $1.10 \mathrm{ft}$ above NAVD 88 . Consequently, IH-1 was inundated during highest high tide on about 79 percent of the days (about 288 days a year) for the period of record at the Jamestown Ferry Pier tide station (fig. 8; table 3). The marsh surface is underlain by organic mud and sand and clayey sediment that slows infiltration and recharge from the surface. The site is more than $300 \mathrm{ft}$ from the closest creek, which is narrow and likely not incised through the mud and clay. Additionally, the difference in water-level altitude across the transect typically was less than $0.10 \mathrm{ft}$ and the directions of the small gradient varied (fig. 16). Such horizontal hydraulic gradients indicate limited horizontal flow and (or) a rapid hydraulic equilibration because water levels equilibrate rapidly within coarse-grained sand. 

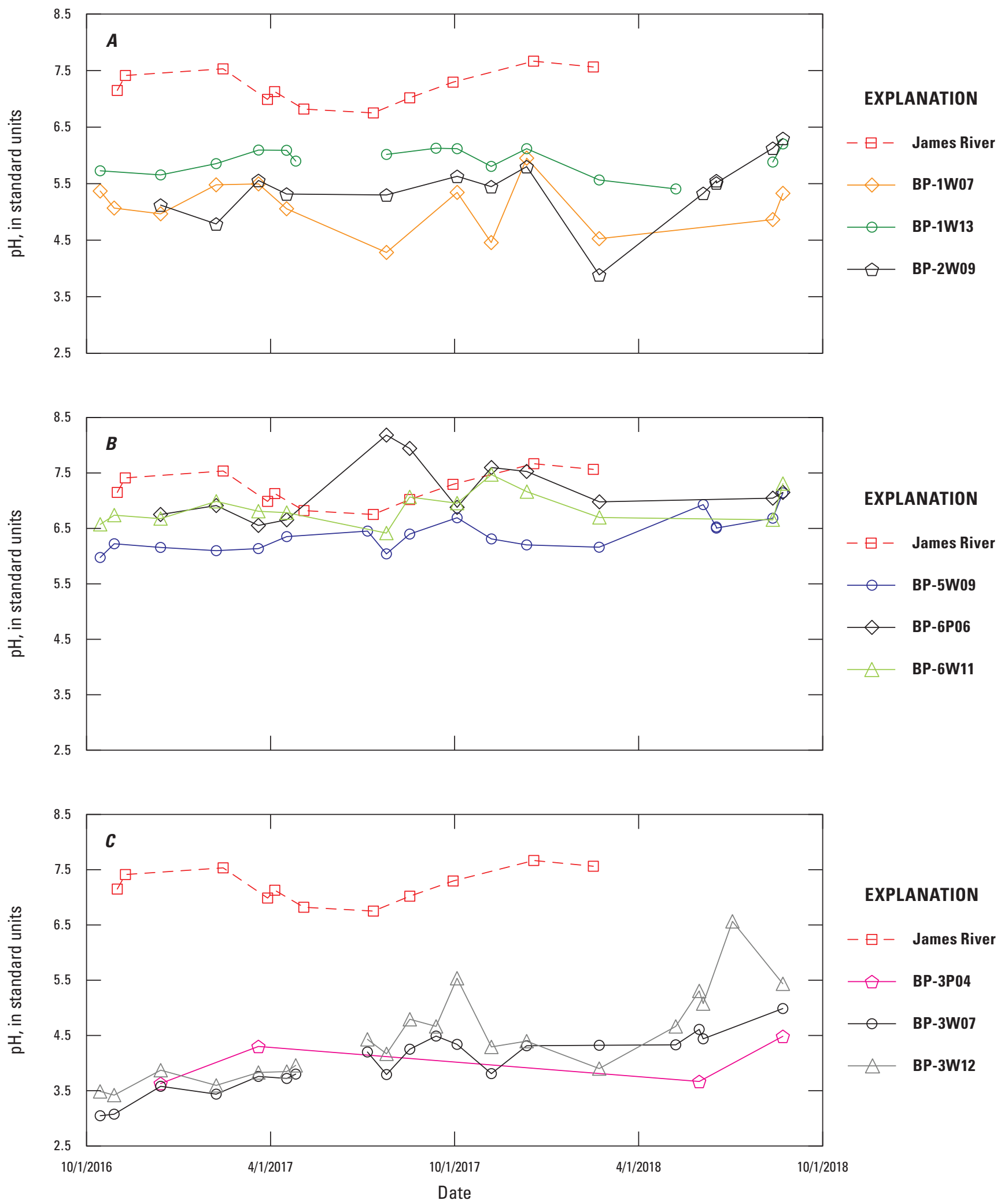

Figure 22. Graphs showing the $\mathrm{pH}$ of water from the James River at the Earthworks and of groundwater from wells and piezometers beneath $A$, the northern marsh (BP-1W07 and BP-1W13) and the northern marsh/forest edge (BP-2W09), $B$, the southern marsh (BP-6P06 and BP-6W11) and the southern marsh/forest edge (BP-5W09), and C, the center of the uplands (BP-3P04, BP-3W07, and BP-3W12) at Black Point, October 2016 to October 2018, Jamestown Island, Colonial National Historical Park, Virginia. 


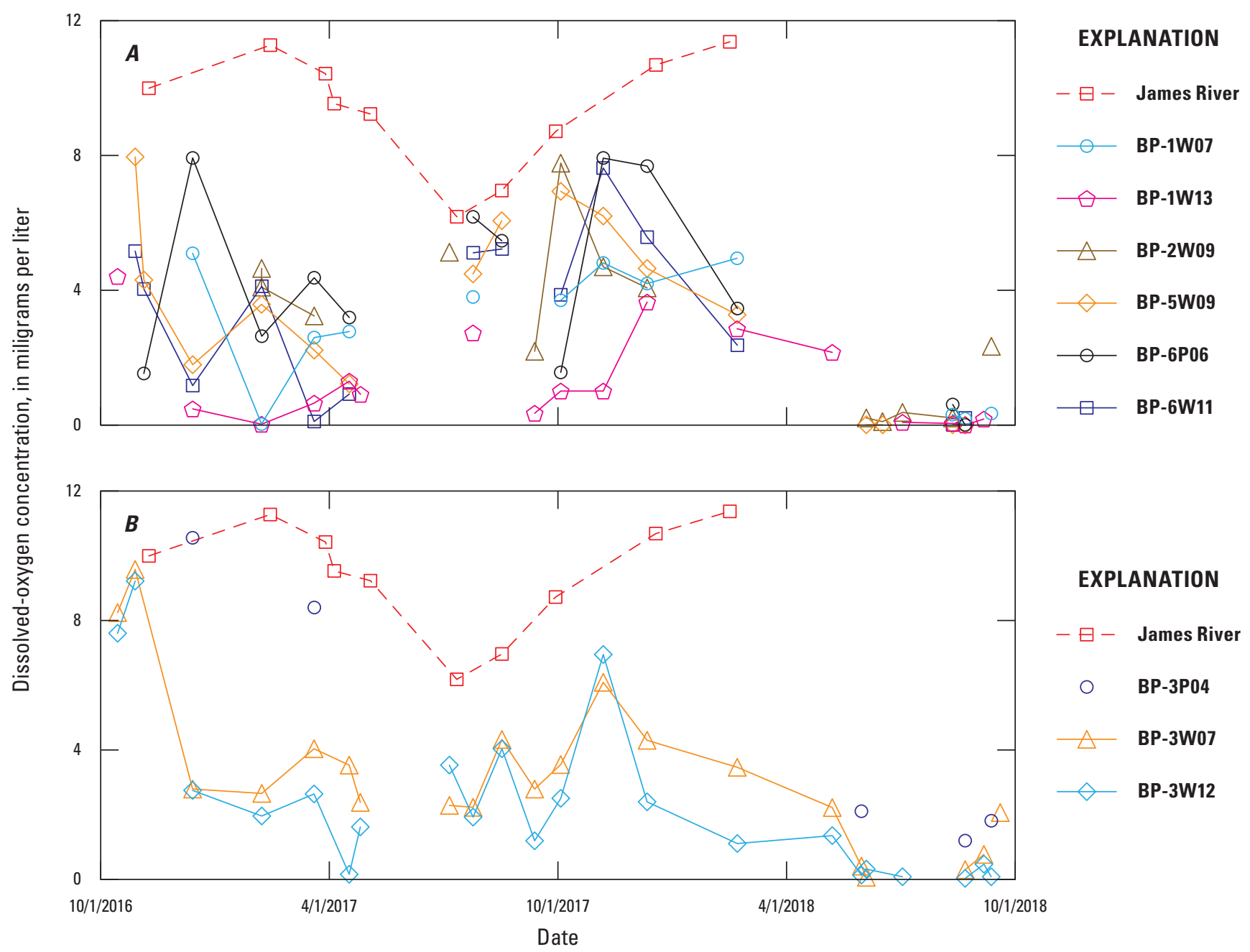

Figure 23. Graphs showing dissolved-oxygen concentrations in water from the James River at the Earthworks and of groundwater in $A$, the deepest wells open to the coarse-grained sand beneath the northern marsh (BP-1W07 and BP-1W13), the northern marsh/forest edge (BP-2W09), the southern marsh/forest edge (BP-5W09), and the southern marsh (BP-6P06 and BP-6W11); and B, wells open to different depths and sediment types beneath the middle of the uplands (BP-3) at Black Point, October 2016 to October 2018, Jamestown Island, Colonial National Historical Park, Virginia.

The organic marsh sediment was expected to deplete dissolved oxygen in groundwater, but this was not indicated with certainty by data from the Island House or Black Point (fig. 4). No wells or piezometers could be constructed open to the organic sediment that could produce enough water to measure dissolved oxygen at either site. All wells and piezometers are open to coarse-grained sand, fine-grained sand, or clayey sediment like that beneath the uplands (fig. 5). Beneath and adjacent to the marsh at the Island House (fig. 17) and both marshes at Black Point (fig. 23), dissolved-oxygen concentration typically was higher in the fine-grained sand or clayey sediment directly underlying the marsh sediment than in the coarse-grained sand. This distribution of dissolved-oxygen concentration can result from numerous combinations of flow paths. Beneath the uplands at Black Point (BP-3), dissolvedoxygen concentrations typically were greater in the shallower sediments; the largest difference was during the nongrowing season when the most recharge occurred (fig. 23B). The higher dissolved-oxygen concentration (fig. 23B) and higher specific conductance (fig. 21) in the shallower sediment are consistent with freshwater recharge dissolving residual salts in unsaturated sediment.

Groundwater $\mathrm{pH}$ from all sites at the Island House was greater than 5.0, in contrast to values less than 4.0 beneath the uplands at Black Point. At the Island House, little of the saline groundwater beneath the uplands likely became anoxic by flowing through organic marsh sediment, and then reoxygenated to form sulfuric acid, as indicated by the highest water levels at the forest/marsh edge (IH-2). This supports the proposed inundation recharge as the source for the saline water at $\mathrm{IH}-2$ with limited lateral flow through organic marsh sediment. The lowest $\mathrm{pH}$ of groundwater beneath the Black Point uplands ranged from 3.1 in fine-grained sand to 3.4 in coarsegrained sand and increased over time (fig. 22B), in contrast to 
$\mathrm{pH}$ values of 5.5 to 6.8 beneath the marshes. The difference in $\mathrm{pH}$ between the marshes and the low-altitude upland occurred laterally over about $50 \mathrm{ft}$ in a temporally persistent pattern. The low $\mathrm{pH}$ beneath the uplands at Black Point suggests that lateral flow from the marsh to the upland occurred, even if the source of the more saline groundwater was recharge from the surface, to produce the anoxic conditions followed by the oxic conditions needed to lower the $\mathrm{pH}$. The variable lateral hydraulic gradients indicate water flowed from the marshes to the uplands at least part of the time.

\section{Other Study Sites}

Groundwater levels at Tour Road 1 fluctuated in a similar pattern and were at similar altitudes at all depth intervals throughout the period. TR-1W25, TR-1P17, and TR-1P07 had only small vertical gradients that varied in direction (fig. 24A). Levels in TR-1P10 were similar to TR-1W25, TR-1P17, and TR-1P07 from July through November 2017 but diverged from that pattern through September 2018. Throughout most of the study, the water-level altitude at the Tour Road 1 transect suggested an overall downward gradient.

The specific conductance of groundwater from piezometers with depths to $10 \mathrm{ft}$ at TR-1 was about 70 to $230 \mu \mathrm{S} / \mathrm{cm}$ (fig. 24B), whereas that of groundwater from TR-1P17 and TR-1W25 ranged from approximately 200 to $2,170 \mu \mathrm{S} / \mathrm{cm}$, which reflected fresh to slightly saline water (table 2). Consequently, fresh groundwater overlies slightly saline groundwater at this location.

The $\mathrm{pH}$ of groundwater at TR-1 ranged from 4.6 to 7.9 (fig. 24C). The highest (TR-1P05) and lowest (TR-1P17) pH values were measured on April 3, 2018, whereas the $\mathrm{pH}$ at these sites was within 0.3 standard units on April 11, 2017. The $\mathrm{pH}$ of groundwater from TR-1W25 typically was less than 6.0 and less than that of groundwater in shallower intervals in the cluster throughout the period.

At Tour Road 2, groundwater levels followed a similar pattern at all depth intervals from July 2017 to October 2018 (fig. 25A). The altitudes of groundwater levels in the two deeper intervals (TR-2P13 and TR-2W29) were similar. The altitudes of groundwater levels in the two shallower intervals (TR-2P05 and TR-2P09) also were similar and similar to or higher than those of the deeper intervals. Vertical gradients varied throughout the period, but were generally downward or minimal.

Based on specific conductance, groundwater at Tour Road 2 was slightly to moderately saline (fig. $25 B$; table 2). Specific conductance ranged from about 2,240 to $9,830 \mu \mathrm{S} /$ $\mathrm{cm}$, with only 2 of 47 values less than the highest two values at TR-1 (fig. 25B). Specific conductance of groundwater from the two deepest intervals (TR-2W13 and TR-2W29) was similar but less than that of the two shallowest intervals (TR-2P05 and TR-2P09), which also were similar to each other. The denser and more saline water was in the shallow, clayey part of the aquifer, whereas the less dense, less saline water was in the deep, coarse-grained part of the aquifer. The specific conductance of groundwater from TR-2W13 and TR-2W29 was relatively stable and ranged from 2,240 to $4,100 \mu \mathrm{S} / \mathrm{cm}$, whereas that of groundwater from TR-2P05 and TR-2P09 was greater and more variable $(4,740$ to $9,830 \mu \mathrm{S} / \mathrm{cm})$.

The $\mathrm{pH}$ of groundwater from the deep intervals at TourRoad 2 (TR-2W29 and TR-2W13) differed appreciably from the shallow intervals (TR-2P05 and TR-2P09, fig. 25C). The $\mathrm{pH}$ of groundwater from each of the deep, less saline intervals was similar and close to neutral (5.7 to 6.8), whereas the shallow, more saline groundwater was more acidic (3.4 to 5.5).

Groundwater levels at most sites at the Earthworks followed a similar pattern, which generally was higher in October 2016, November 2017, and April and September 2018 than in July 2017 and February and August 2018 (fig. 26). Groundwater levels at the marsh/forest edge (EW-8) ranged from -0.43 to $1.92 \mathrm{ft}$ (2.35-ft range) above NAVD 88; levels in the marsh (EW9) had a similar range (2.27 ft) but a slightly higher altitude ( 0.37 to $2.64 \mathrm{ft}$ above NAVD 88). Groundwater levels beneath the uplands were similar among most wells much of the time and ranged from -1.41 to $2.33 \mathrm{ft}$ (3.74-ft range) above NAVD 88. Wells at the marsh/forest edge (EW-8) and in the marsh (EW-9) at the Earthworks were in the southern part of the same marsh as wells in the southern marsh of Black Point (BP-6).

Although the specific conductance in BP-6 responded slowly to changes in salinity of the river (fig. $21 B$ ), groundwater from the marsh well at the Earthworks (EW-9W07) responded sharply to the increased specific conductance of the river as it increased from 2,250 to $11,500 \mu \mathrm{S} / \mathrm{cm}$ (fig. 27A). Specific conductance of groundwater beneath the uplands at the Earthworks ranged from 4,520 to $17,900 \mu \mathrm{S} / \mathrm{cm}$ (fig. $27 B$ ). All upland wells at the Earthworks were open to the fine- to medium-grained sand except EW-2W10, which was open to the coarse-grained sand and gravel (fig. 5C). Specific conductance of groundwater from wells in the shallow fineto medium-grained sand increased more quickly in response to the increased specific conductance in the river than water from well EW-2W10, which was located in the underlying coarse-grained sand. The specific conductance of groundwater in the fine-grained sediment at sites EW-2, EW-3, and EW-4 increased almost immediately in response to changes in river salinity but decreased more slowly than the specific conductance of the river. The specific conductance of groundwater from EW-2W06 was the highest throughout most of the period and matched that of the peak river specific conductance. In contrast to the rapid responses in the fine-grained sediment, response to changes in the river was slow in groundwater in coarse-grained sand (EW-2W10).

The $\mathrm{pH}$ of groundwater at sites beneath the marsh (EW-9) and at the marsh/forest edge (EW-8) ranged from 6.1 to 7.4, a little lower than that of the James River (fig. 28A) and higher than that of groundwater beneath the upland sites (fig. $28 B$ ). The $\mathrm{pH}$ of groundwater at sites EW-2, EW-3, and EW-4 beneath the uplands varied appreciably, from 3.3 to 5.6 (fig. $28 B$ ), and was usually less than 4.5 . The $\mathrm{pH}$ of groundwater at site EW-1, the site adjacent to the river, ranged from 5.2 to 6.4, between that of the upland wells and the river. 


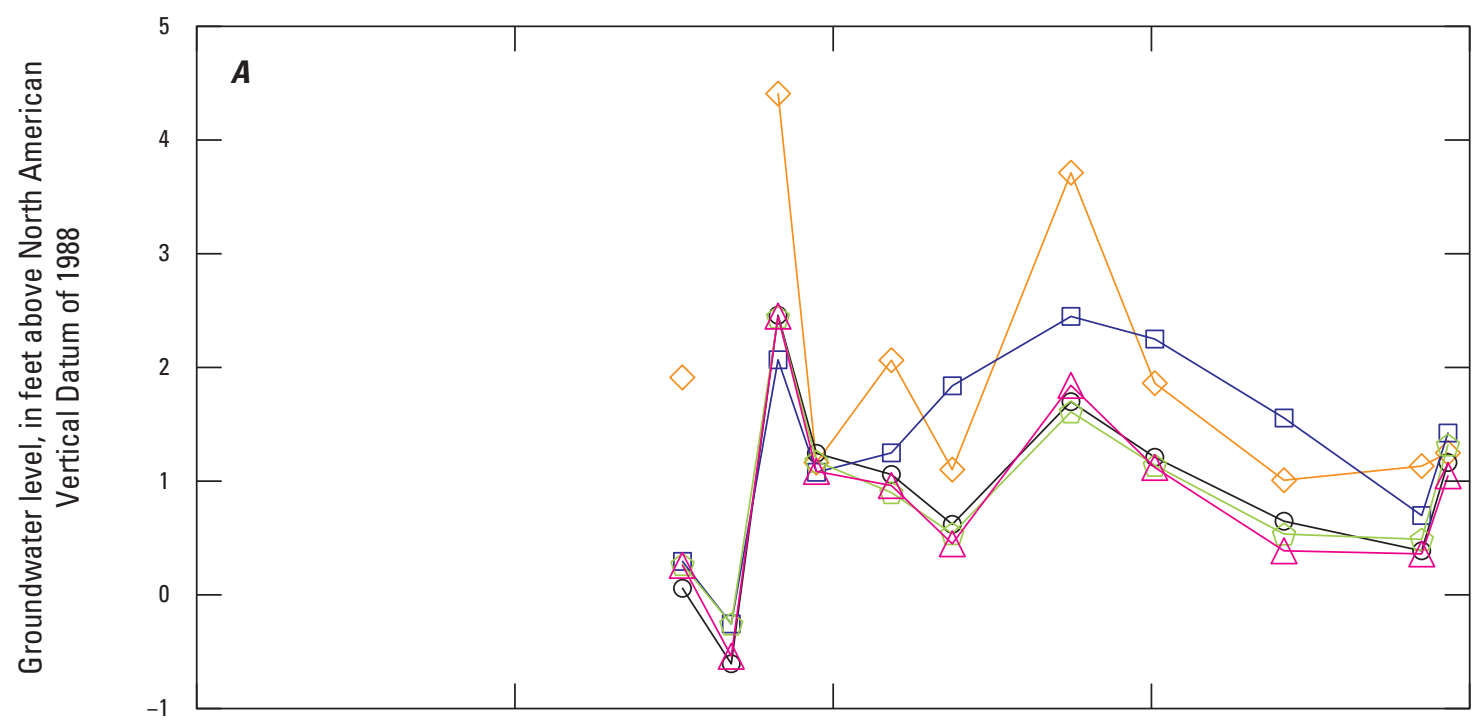

EXPLANATION

$\diamond$ TR-1P05

-

$\square$ TR-1P10

$\triangle \quad$ TR-1P17

$\triangle$ TR-1W25

LAND SURFACE

TR-1P05 - 4.65 feet

TR-1P07 - 4.61 feet

TR-1P10 - 4.63 feet

TR-1P17 - 4.45 feet

TR-1W25 - 4.69 feet

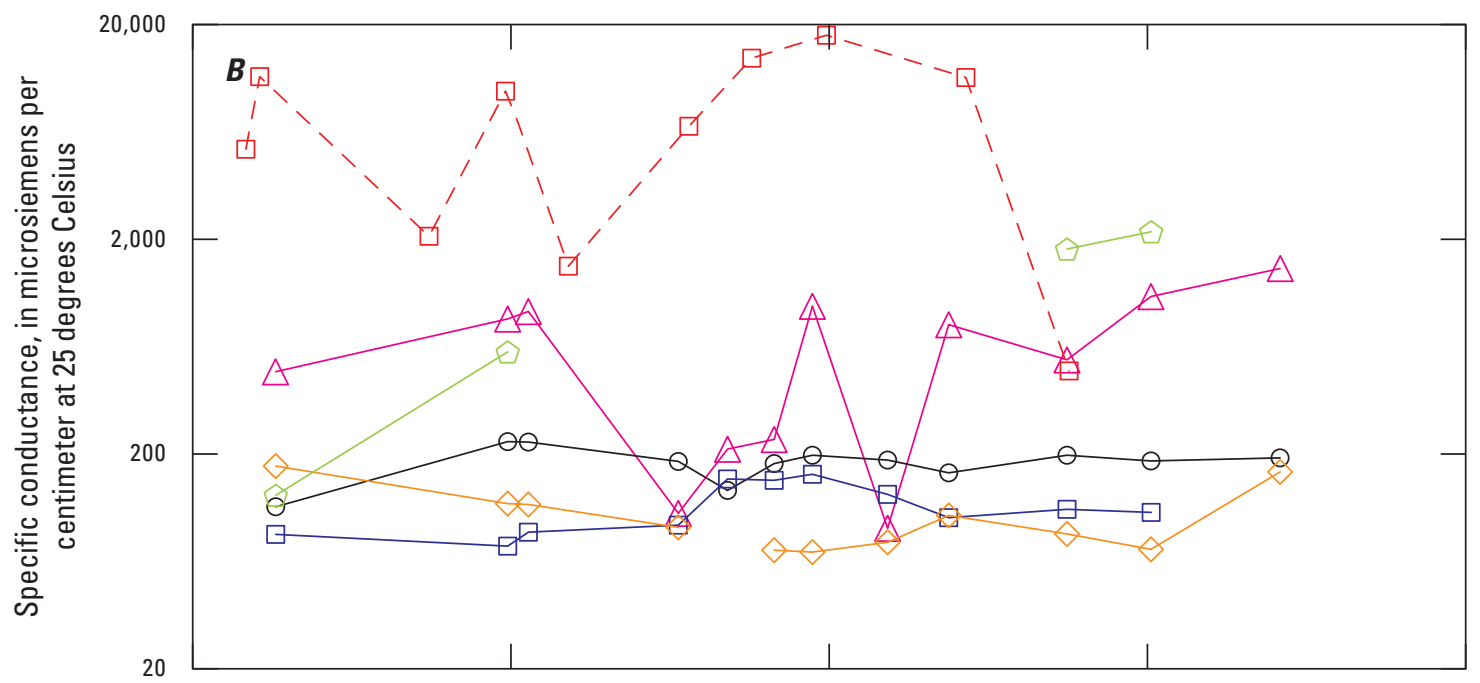

\section{EXPLANATION}

$-\boxminus-\quad$ James River

$\smile$ TR-1P05

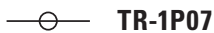

$\square$ TR-1P10

$-\triangle$ TR-1P17

$\triangle \quad$ TR-1W25

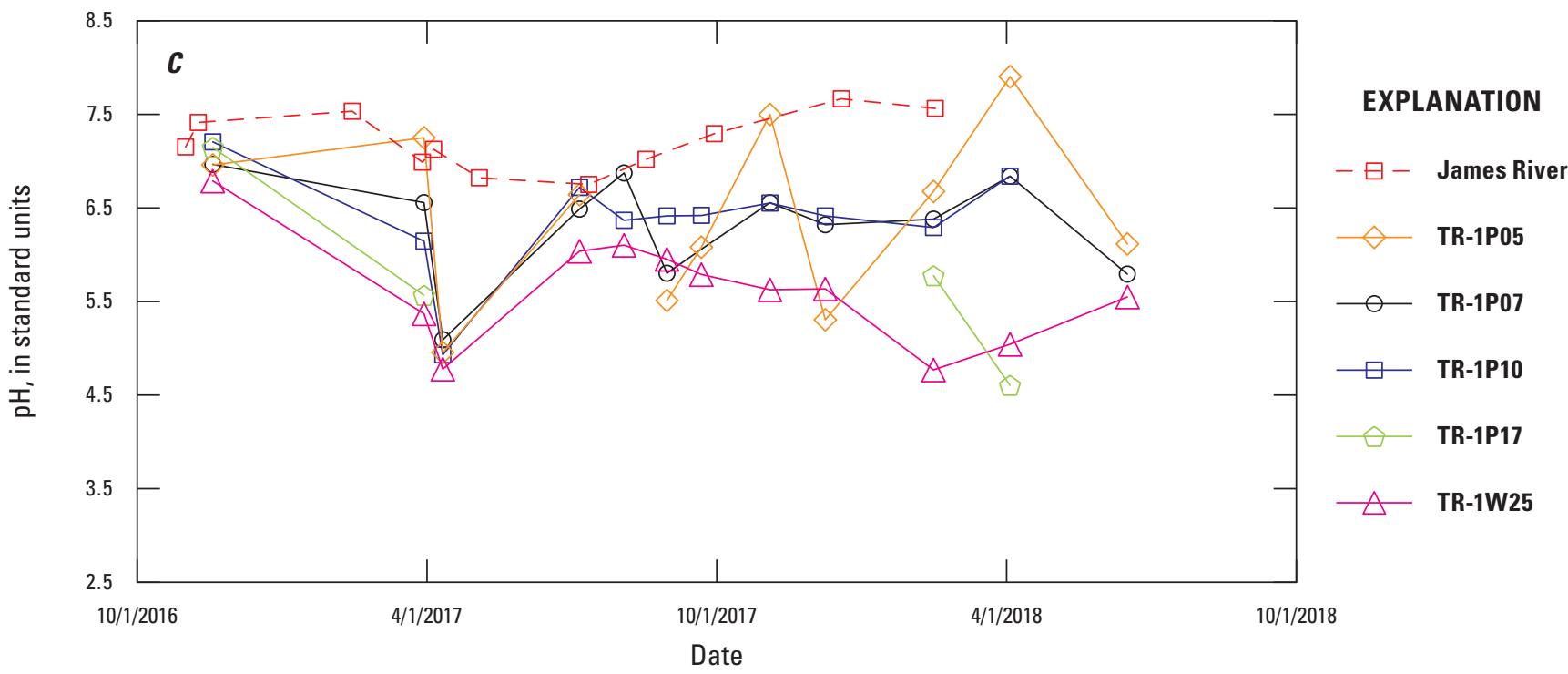

Figure 24. Graphs showing $A$, water-level altitude, $B$, specific conductance, and $C, \mathrm{pH}$ of water from the James River at the Earthworks and of groundwater at Tour Road 1, October 2016 through August 2018, Jamestown Island, Colonial National Historical Park, Virginia. 


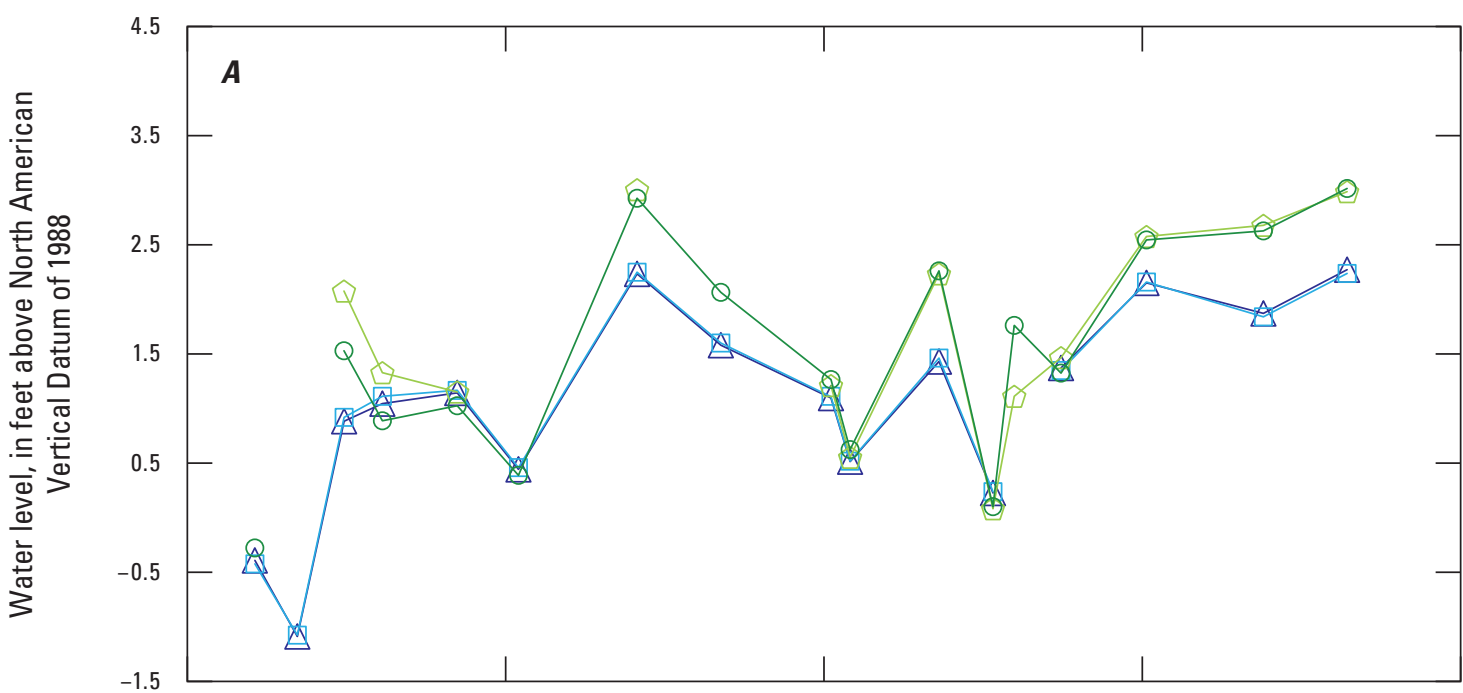

EXPLANATION

$\triangle$ TR-2P05

$\square \quad$ TR-2P07

- TR-2P09

$\triangle \quad$ TR-2W29

LAND SURFACE

TR-2P05 - 3.99 feet

TR-2P07 - 4.36 feet

TR-2P09 - 4.06 feet

TR-2W29 - 4.46 feet

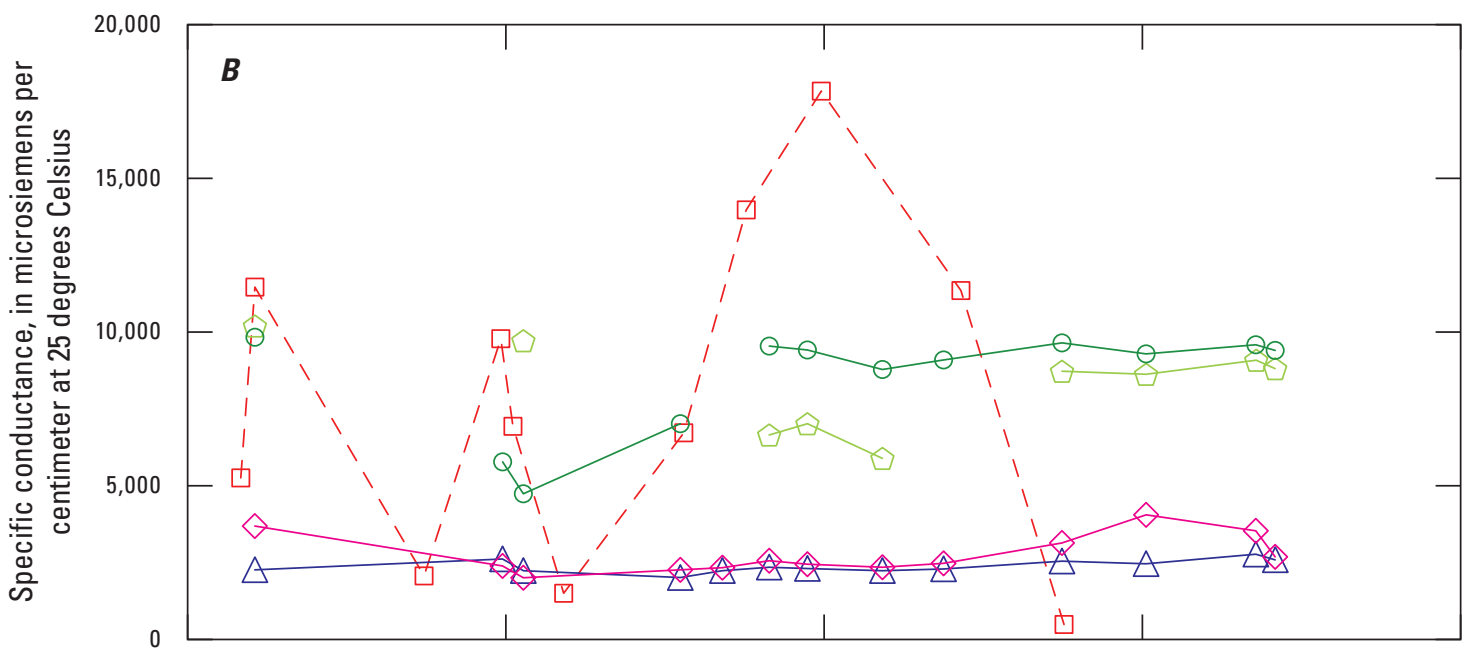

EXPLANATION

$-\boxminus-\quad$ James River

TR-2P05

O- TR-2P09

$\diamond$ TR-2W13

$\triangle \quad$ TR-2W29

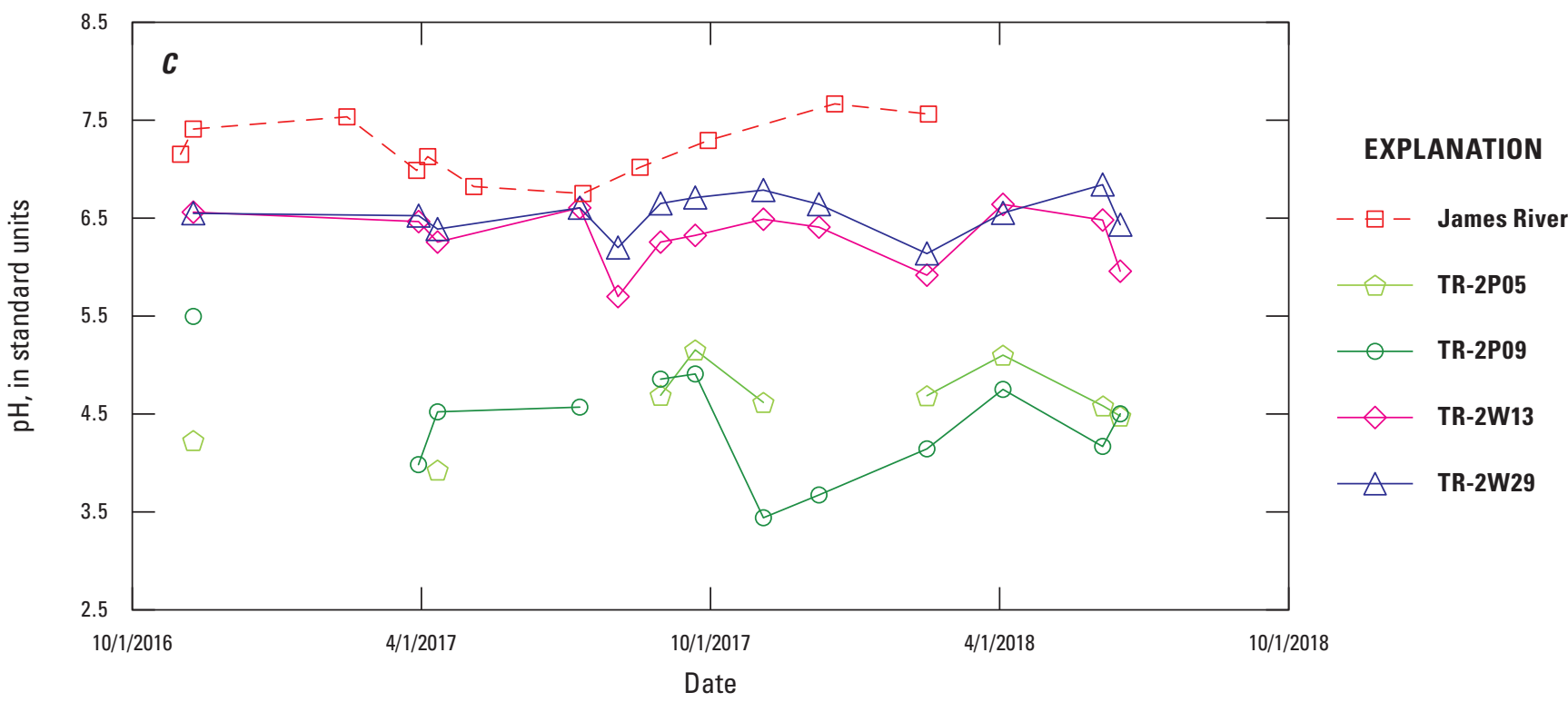

Figure 25. Graphs showing $A$, water-level altitude, $B$, specific conductance, and $C, \mathrm{pH}$ of water from the James River at the Earthworks and of groundwater at Tour Road 2, October 2016 through August 2018, Jamestown Island, Colonial National Historical Park, Virginia. 


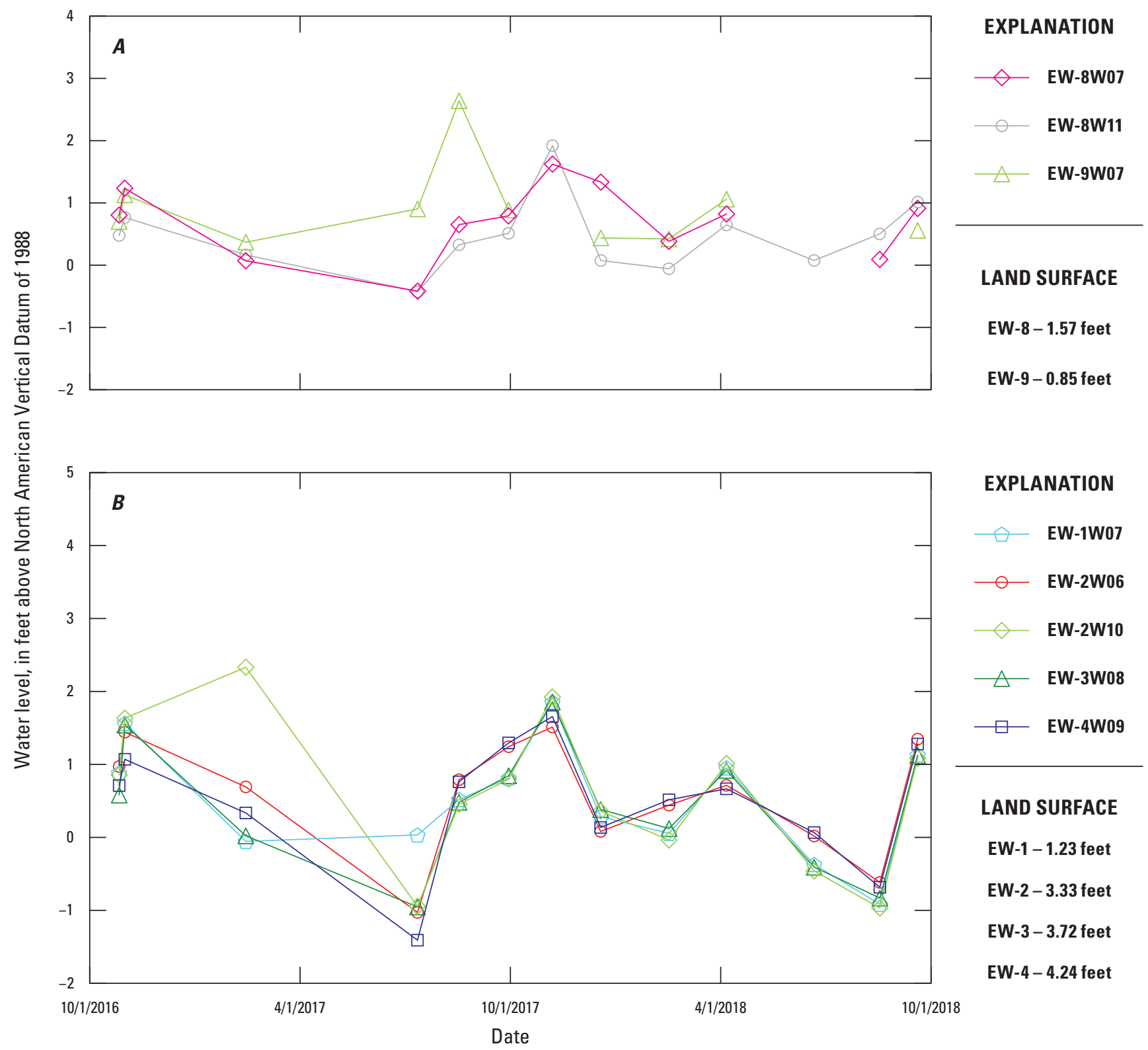

Figure 26. Graphs showing the altitude of groundwater levels $A$, beneath and at the marsh/forest edge, and $B$, beneath the upland ridge at the Earthworks, October 2016 through August 2018, Jamestown Island, Colonial National Historical Park, Virginia.

Although EW-9W07 is in the same marsh that surrounds BP-6, the response in EW-9W07 to changing river salinity (fig. 28A) was more rapid than at BP-6 (fig. 21B) or the nearby EW-8 at the marsh/forest edge (fig. 28A). This response results from the absence of low permeability sediment at EW-9 that is present at other sites. The marsh at the Earthworks was the only site in the study area where the upper clayey sediment was absent. The clayey sediment appears to have been removed and used as material for construction of a nearby earthen fortification. Similarly, a narrow marsh between the upland transect and the fortification appears to be a linearly cut borrow area through the upland ridge used to construct the adjacent part of the fortification. The land-surface altitude at site EW-9 is $0.85 \mathrm{ft}$ above NAVD 88, so the site was inundated during the daily highest high tide about 89 percent of the days (325 days per year), similar to that beneath the part of the marsh south of Black Point (fig. 8; table 3). The delayed response at BP-6 compared to EW-9 results from the distance between BP-6 and EW-9, where the vertical connection is greater.

\section{Long-Term Monitoring}

Long-term monitoring can identify and track changes in groundwater hydrology and chemistry caused by tides, storm surges, and sea-level rise while optimizing monitoring costs. 


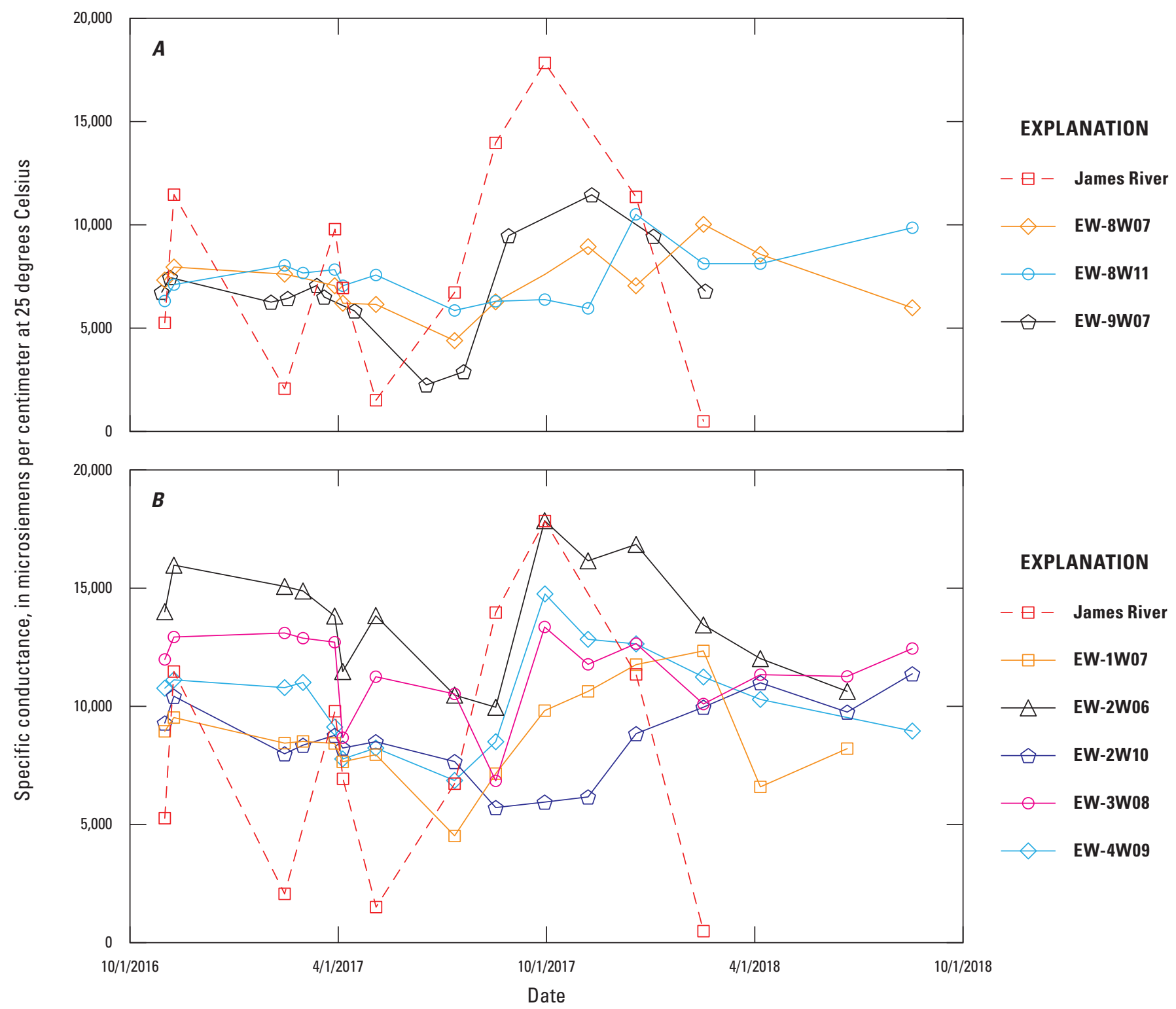

Figure 27. Graphs showing the specific conductance of water from the James River and of groundwater $A$, beneath the marsh and at the marsh/forest edge (EW-8W07, EW-8W11, and EW-9W07), and B, beneath the upland ridge at the Earthworks (EW-1W07, EW-2W06, EW-2W10, EW-3W08, and EW-4W09), October 2016 through August 2018, Jamestown Island, Colonial National Historical Park, Virginia.

Modifications to monitoring include changes in sites, types of analyses, and frequency and timing of analyses. Continuous measurements of groundwater levels, dissolved oxygen, specific conductance, and $\mathrm{pH}$ would be valuable additions to the monitoring conducted during this project. Continuous measurements could help differentiate slow changes caused by sea-level rise from rapid, daily-to-seasonal changes caused by groundwater recharge, tides, discharge, and storm surges. The two deepest wells in the monitoring network were constructed to allow for the running of induction logs through the full thickness of the Surficial aquifer to monitor changes in salinity.

Additional wells and piezometers at the Earthworks and the Island House sites would further the understanding of the hydrology and chemistry. At the Earthworks, a transect of wells and piezometers that extends from the river south of the transect, across and approximately perpendicular to the middle of the transect, and into the marsh north of the transect could clarify the relative influence of the river and the marsh on groundwater chemistry. At the Island House, additional wells and piezometers that extend south of IH-6 to the marsh south of the ridge could help determine the extent and possibly the cause of the nearly saline water at IH-6. Additional wells or piezometers at existing sites at different depths would improve the vertical resolution of conditions.

During the risk assessment of the archaeological sites, the need for monitoring wells or piezometers at each archaeological site was discussed. The number and placement of 

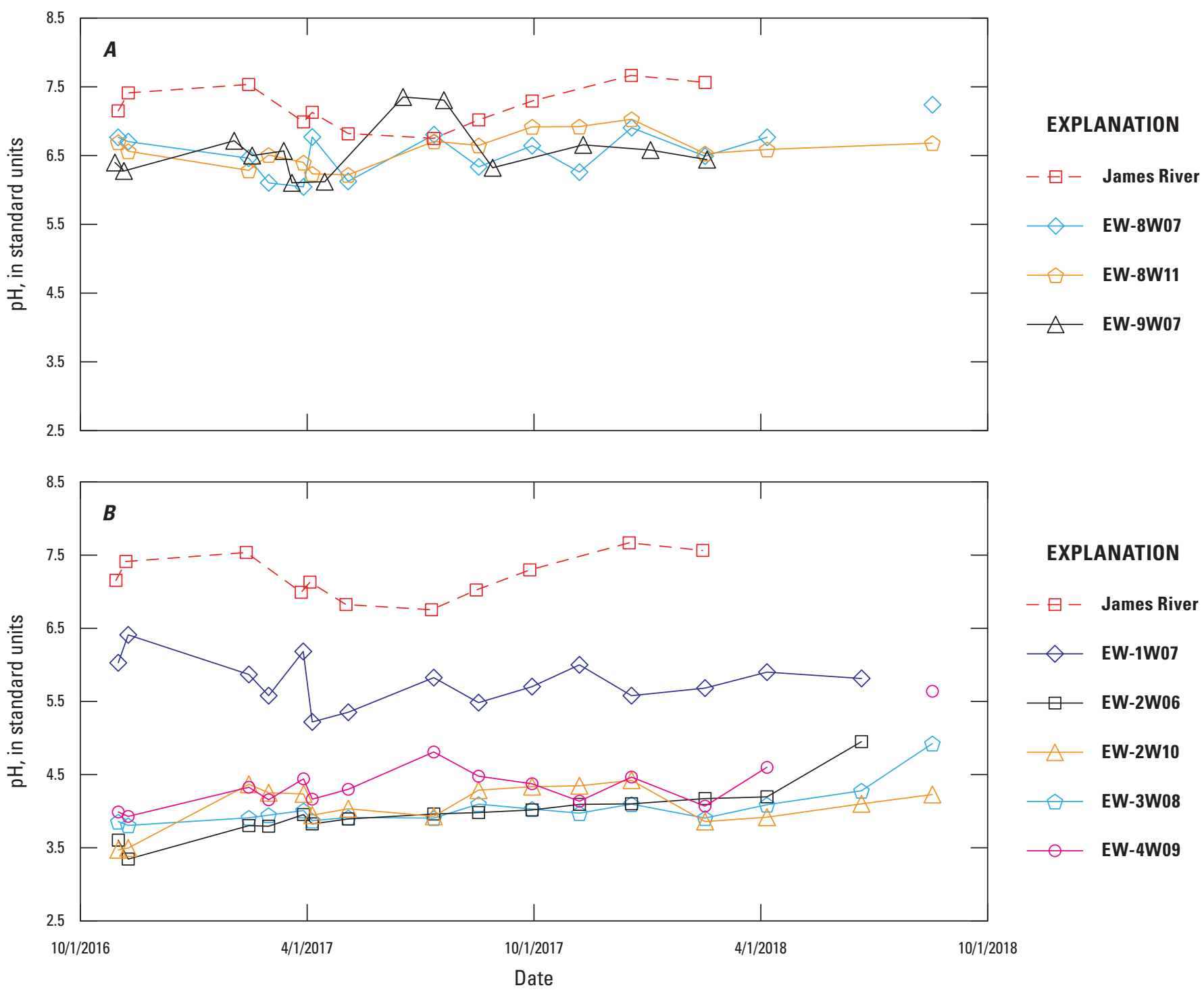

Figure 28. Graphs showing $\mathrm{pH}$ of water from the James River and of groundwater $A$, beneath the marsh and at the marsh/forest edge (EW-8W07, EW-8W11, and EW-9W07), and B, beneath the upland ridge at the Earthworks (EW-1W07, EW-2W06, EW-2W10, EW-3W08, and EW-4W09), October 2016 through August 2018, Jamestown Island, Colonial National Historical Park, Virginia.

wells and piezometers and the type of monitoring depends on the objectives at each site. In all sediment types, a well or piezometer can be used for periodic or continuous water-level measurements, but a well is needed for continuous water-quality measurements. For periodic water-quality measurements, which require the pumping of water, a well or piezometer can be used in coarse-grained sediment. In fine-grained sediment, however, a piezometer from which water could be entirely pumped is needed so that the chemistry of water that enters the piezometer is minimally altered by aeration.

A log that documents the known or suspected causes of unusually high or low tides (for example, nor'easters or tropical systems), unusually large discharges and storm surges, and other potential causes of change would facilitate the analysis of results. Recording such factors as time, duration, location, strength of winds, amount of precipitation, and other possible contributing factors can be critical.

Additional sampling and assessments could contribute to better understanding of processes, by targeting specific times, sites, wells, and piezometers. Examples include periodic sampling and analysis of major ions and other constituents in groundwater, age-dating groundwater, assessing the pathway/ mechanism by which saline water enters the fine-grained sediment, and developing soil $\mathrm{pH}$ and salinity sampling and measurement protocols. Geophysical techniques (such as GEM-2 [http://www.geophex.com/index.html] or towed time-domain electromagnetic (tTEM) imaging system could be to assess the lateral salinity distribution or further elucidate changes in lithology. Likewise, helicopter electromagnetic resistivity could provide an assessment of the spatial distribution of 
salinity (Moyer and others, 2013), although the resolution would likely be insufficient to distinguish a shallow freshwater lens. The design of such assessment techniques would need to be targeted to answer specific questions.

The pathway and (or) mechanism by which acidic, saline water enters and remains in the fine-grained sediment is uncertain and might vary spatially and (or) temporally. The physical and chemical processes that determine when acidic, saline water will enter areas not currently affected are not known. Additionally, sediment samples need to be evaluated in a laboratory for the presence of pyrite, which will help determine if specific sites could be subject to future acidification.

Because the acidic, saline water at the water table can be drawn into shallow soils near land surface by evaporation and (or) hydraulic redistribution, measuring soil salinity and $\mathrm{pH}$ would provide a screening tool to assess where near-surface soil is acidic and (or) saline and likely damaging cultural resources. The roles of ET and recharge are important considerations in developing the protocol for these analyses. ET draws acidic, saline water up from the water table toward land surface during the growing season. In contrast, during the nongrowing season, precipitation serves as recharge and can flush the acidic, saline water deeper into the soil and replace it with more neutral $\mathrm{pH}$ water. Consequently, the timing and depth of sample collection is critical to the use of soil $\mathrm{pH}$ and salinity analyses as screening tools to identify the archaeological sites at risk.

\section{Management Implications}

The presence of acidic, saline water at the water table in some locations is a critical issue on Jamestown Island. The potential of acidic, saline water drawn from the water table by hydraulic redistribution by vegetation into shallow soils that contain artifacts is an ongoing threat. This process could cause the water in shallow unsaturated soil to become both saline and acidic. Such conditions could damage the artifacts, cultural features, ecological resources, and infrastructure, as well as potentially contribute to the stress and mortality of upland trees. Acidic, saline water at the water table in the uplands at Black Point appears to be causing stress to trees, in contrast to healthy trees at the Island House, where acidic, saline water was not measured. The conditions observed at Black Point likely occur beneath low-altitude uplands across the island and may be encountered at higher altitudes across the island as sea level rises.

Understanding changes in groundwater caused by sealevel rise and storm surges would be improved by continued monitoring of groundwater levels and chemistry. Information on these changes can be used for updating and improving the general adaptive management strategy and specific Adaptation and Resiliency Action Plans for individual sites. Because of the density inversion and acidic, saline water at the water table identified by this study, continued monitoring and additional assessments are critical. A more complete assessment of the pathway for the saline groundwater to enter and remain in the fine-grained sand and clayey sediment to create the density inversion would help to identify additional areas that may develop these conditions as sea level rises. The proposed methods for analyzing soil salinity and $\mathrm{pH}$ are inexpensive ways to get detailed data that can be used to identify areas where acidic, saline water already affects the surficial soil, and identify the potential future development of these conditions.

The typical concern when assessing the effects of sealevel rise is which areas will become inundated by a specified date or with a selected amount of sea-level rise. Because projections of sea-level rise are highly variable, a range of answers can be given that depend on the assumptions made. For both the date and the amount of rise, the magnitude of tides and storm surges is critical. Inundation by a single storm surge, multiple storm surges, or occasional high tides can cause the conditions observed at Black Point. Because the effects of periodic high tides and storm surges appear to be among the factors that created those conditions, identifying parts of the island subject to these conditions is critical.

Much of Jamestown Island has been inundated periodically since August 13, 2015, based on the tidal record at the Jamestown Ferry Pier tide station (August 13, 2015, through October 1, 2018); the depth and frequency of this inundation depends on the land-surface altitude (fig. 8). Light detection and ranging (lidar)-based land-surface altitude data (National Oceanic and Atmospheric Administration, 2020) indicate that appreciable parts of the island, mainly marshes, are inundated at least once a day for 50 percent of the days of the tidal record during the daily highest high tide, when the tide rises above $1.63 \mathrm{ft}$ above NAVD 88 (fig. 8). Figure 29A shows the extent of inundation on the island at $1.5 \mathrm{ft}$ above NAVD 88 , which occurs 58 percent of the tidal record. With a tide of $2.0 \mathrm{ft}$ above NAVD 88 (fig. 29B), more of the island becomes inundated as water covers more of the marshes. On average, this level occurs at highest high tide on 20 percent of the days (fig. 8), which averages 6 days a month or 72 days a year. With a tide of $2.5 \mathrm{ft}$ above NAVD 88 (fig. 29C), water covers most of the marshes and starts to extend into the edges of the low altitude parts of the uplands. On average, this level occurs at highest high tide on 6.7 percent of the days (fig. 8), which averages 2 days a month or 24 days a year. With a tide of 3.0 $\mathrm{ft}$ above NAVD 88 (fig. 29D) water extends farther into the uplands. Although low parts of the tour road might be covered by some water, most parts of the tour road extensively bounded by water on the map are bridges that cross creeks. On average, this level occurs 2.6 percent of the days (fig. 8 ), which averages less than 1 day a month or 9 days a year. When the tide reaches $5.0 \mathrm{ft}$ above NAVD 88, as during the storm surge of October 4, 2015, much of the island and large parts of the tour road are inundated (fig. 29E). The greatest incremental increase in the extent of the island inundated by highest high tides and (or) storm surges occurs between $2.0 \mathrm{ft}$ (fig. 29B) and $2.5 \mathrm{ft}$ (fig. 29C) above NAVD 88. Such inundation occurs an average of 2 days a month on the daily highest high tides, generally during spring tides (full or new moon) or storm surges. 


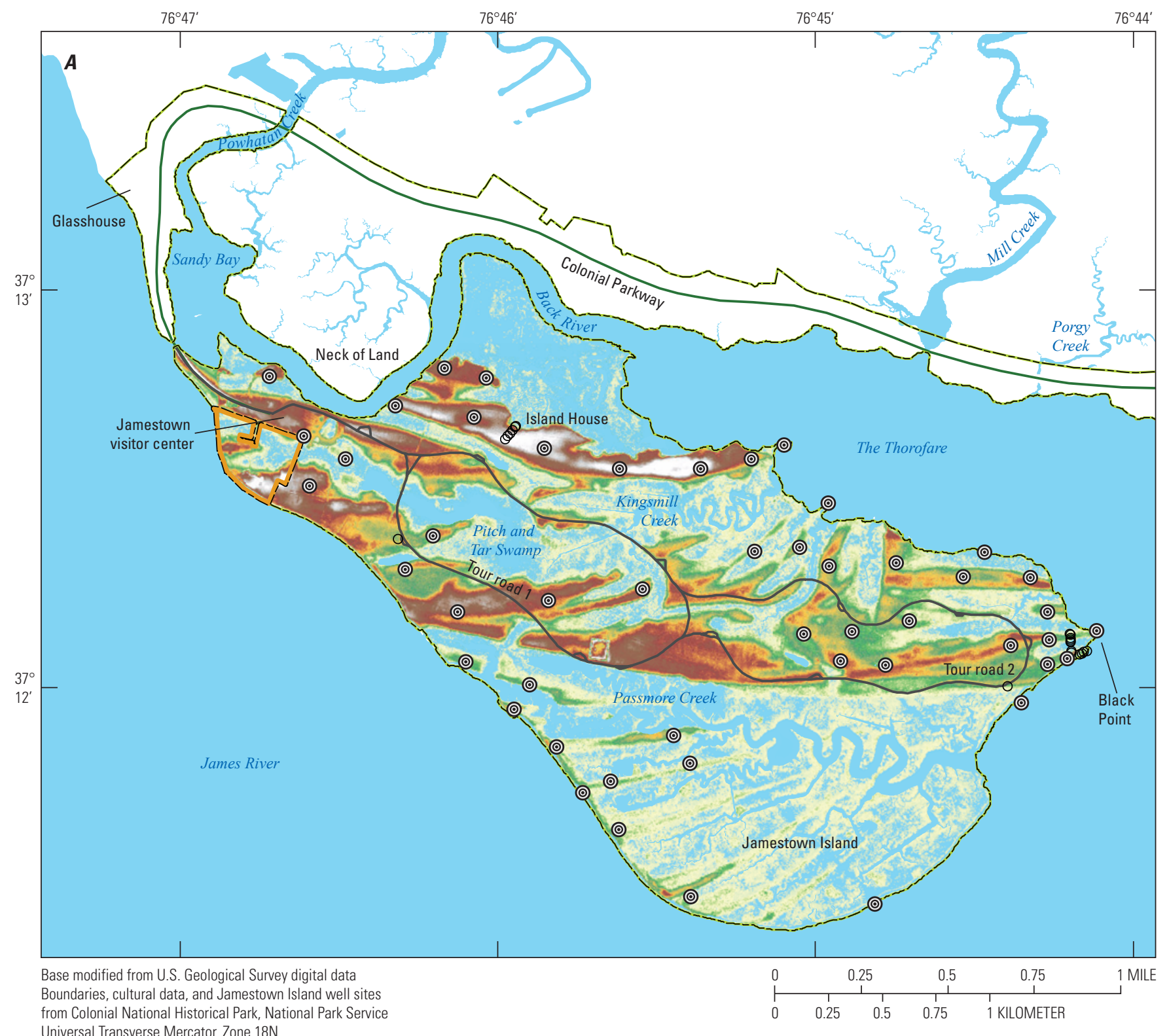

Universal Transverse Mercator, Zone 18N

North American Datum of 1983

EXPLANATION
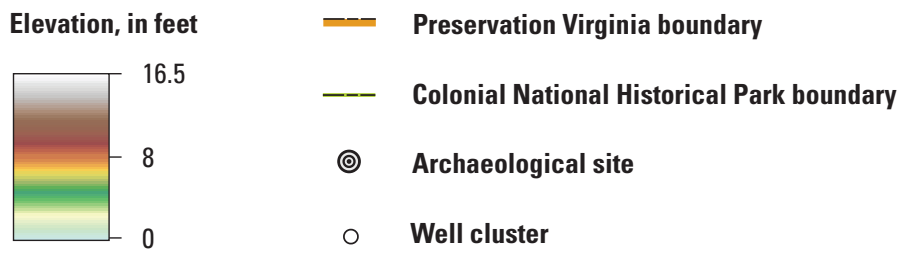

Figure 29. Maps showing the land-surface altitude and areas inundated when the water-surface altitude from high tides or storm surges reaches $A, 1.5 \mathrm{feet}(\mathrm{ft}), B, 2.0 \mathrm{ft}, C, 2.5 \mathrm{ft}, D, 3.0 \mathrm{ft}$, and $E$, $5.0 \mathrm{ft}$ above North American Vertical Datum of 1988 on Jamestown Island, Colonial National Historical Park, Virginia. 


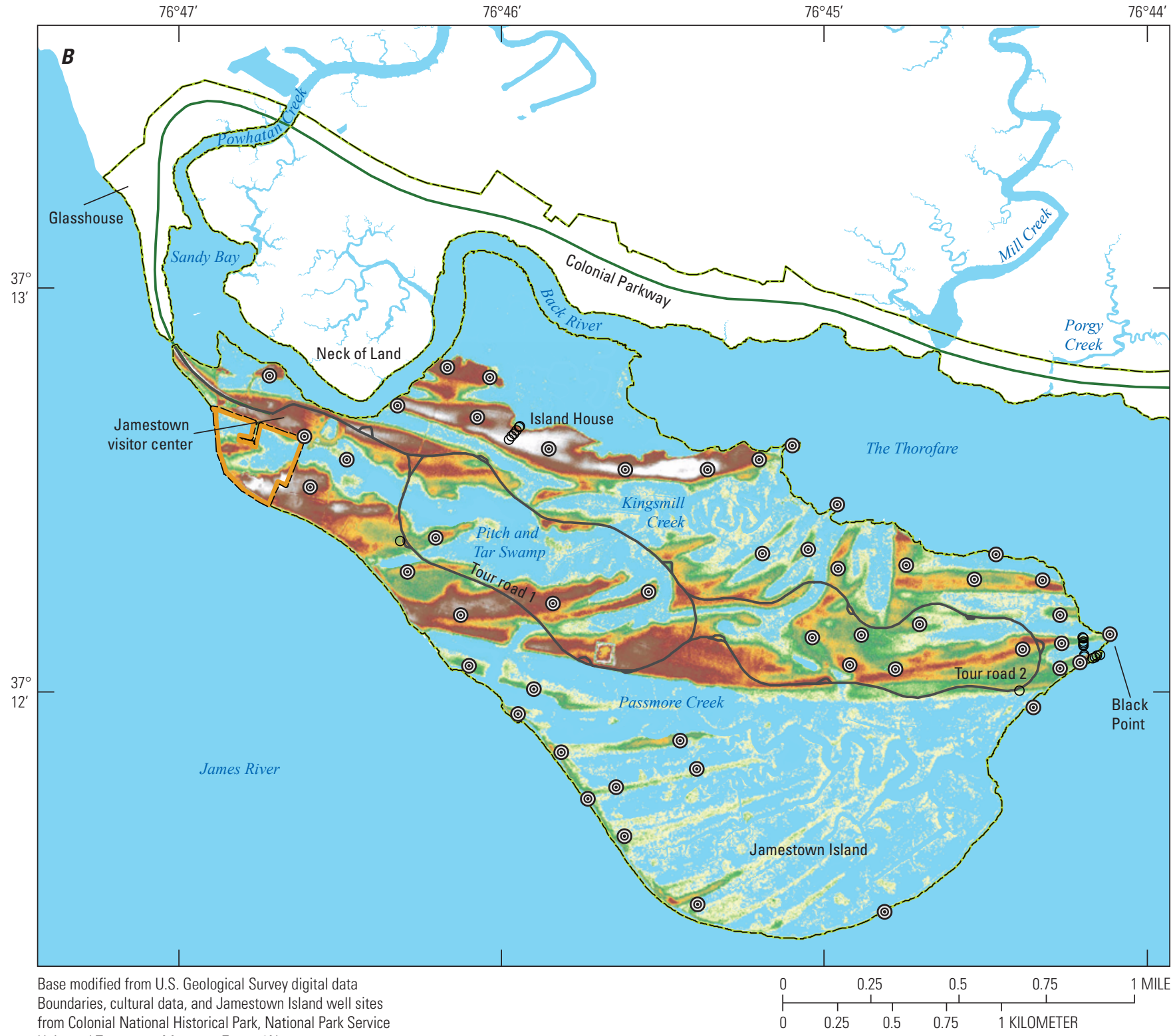

Universal Transverse Mercator, Zone 18N

North American Datum of 1983

\section{EXPLANATION}
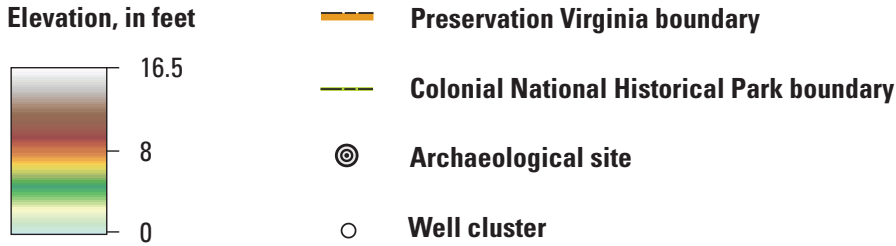

Figure 29. Maps showing the land-surface altitude and areas inundated when the water-surface altitude from high tides or storm surges reaches $A, 1.5 \mathrm{feet}(\mathrm{ft}), B, 2.0 \mathrm{ft}, C, 2.5 \mathrm{ft}, D, 3.0 \mathrm{ft}$, and $E, 5.0 \mathrm{ft}$ above North American Vertical Datum of 1988 on Jamestown Island, Colonial National Historical Park, Virginia.-Continued 


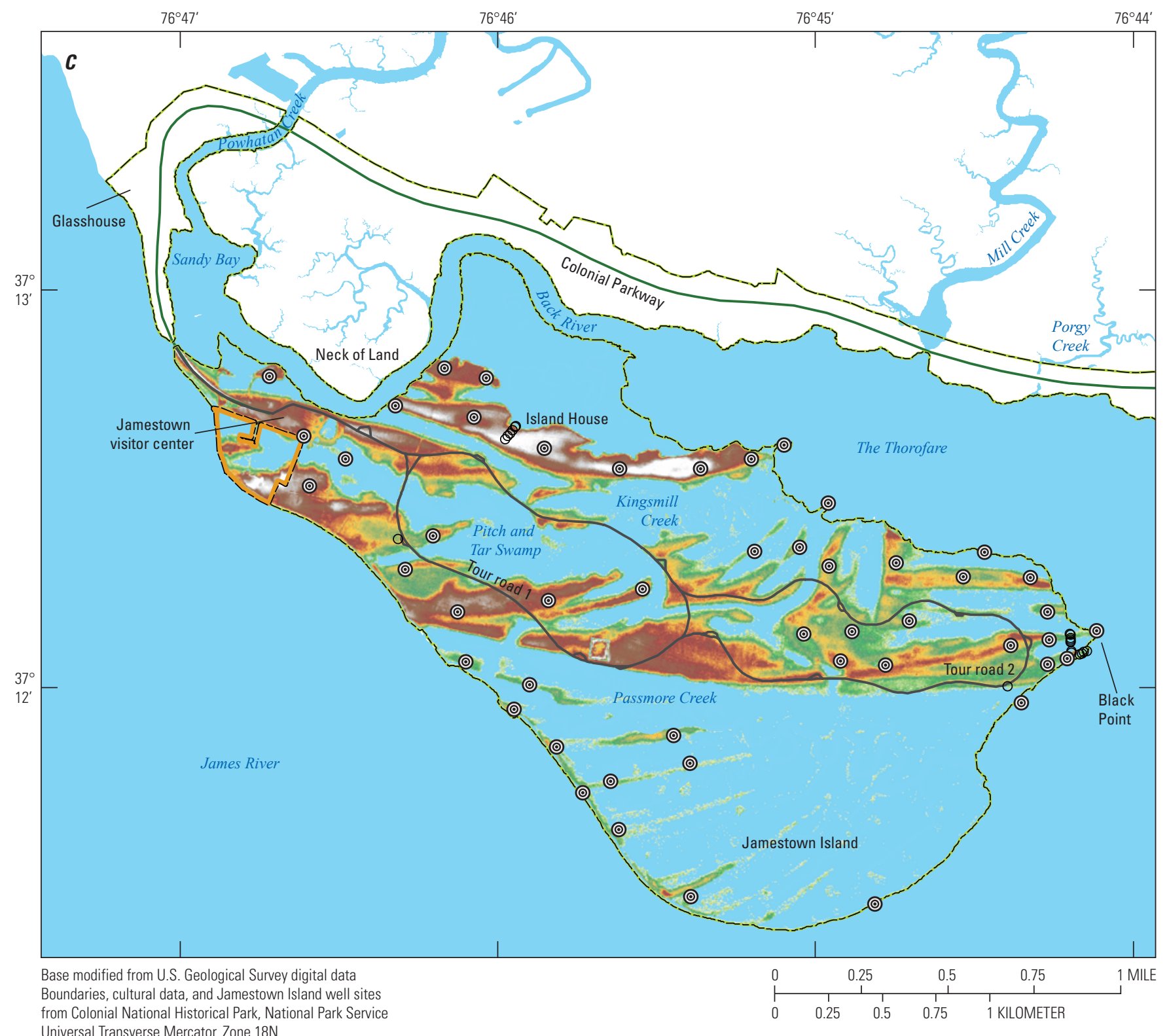

Universal Transverse Mercator, Zone 18N

North American Datum of 1983

\section{EXPLANATION}
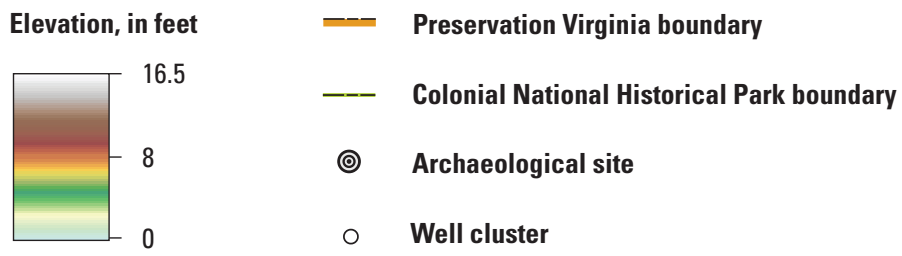

Figure 29. Maps showing the land-surface altitude and areas inundated when the water-surface altitude from high tides or storm surges reaches $A, 1.5 \mathrm{feet}(\mathrm{ft}), B, 2.0 \mathrm{ft}, C, 2.5 \mathrm{ft}, D, 3.0 \mathrm{ft}$, and $E, 5.0 \mathrm{ft}$ above North American Vertical Datum of 1988 on Jamestown Island, Colonial National Historical Park, Virginia._-Continued 


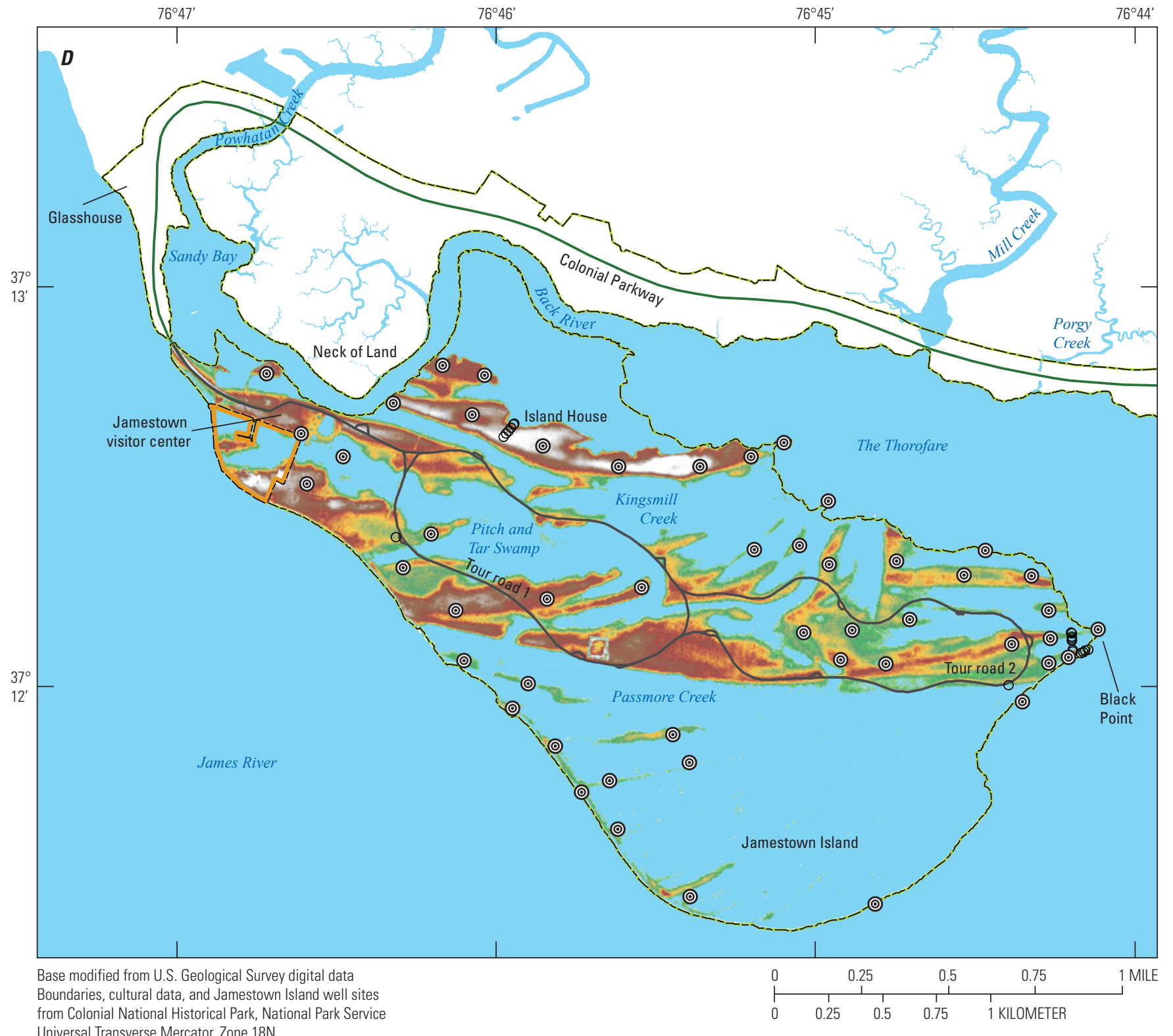
North American Datum of 1983

\section{EXPLANATION}
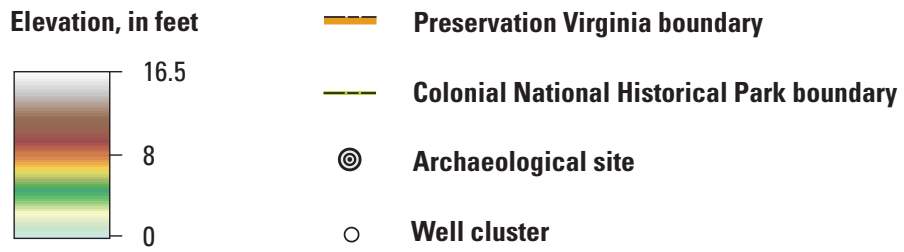

Figure 29. Maps showing the land-surface altitude and areas inundated when the water-surface altitude from high tides or storm surges reaches $A, 1.5 \mathrm{feet}(\mathrm{ft}), B, 2.0 \mathrm{ft}, C, 2.5 \mathrm{ft}, D, 3.0 \mathrm{ft}$, and $E$, $5.0 \mathrm{ft}$ above North American Vertical Datum of 1988 on Jamestown Island, Colonial National Historical Park, Virginia.-Continued 


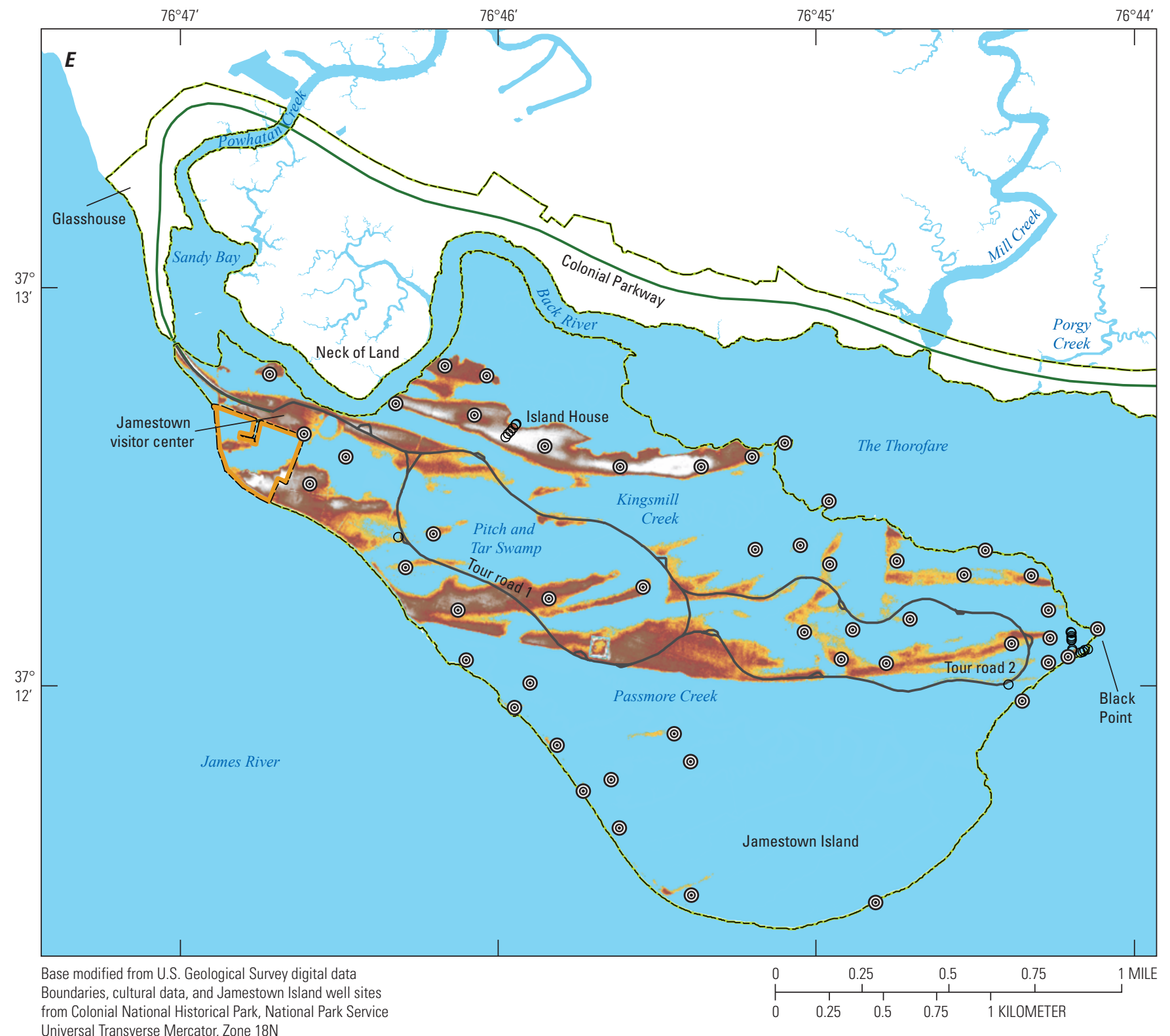

Universal Transverse Mercator, Zone 18N
North American Datum of 1983

\section{EXPLANATION}
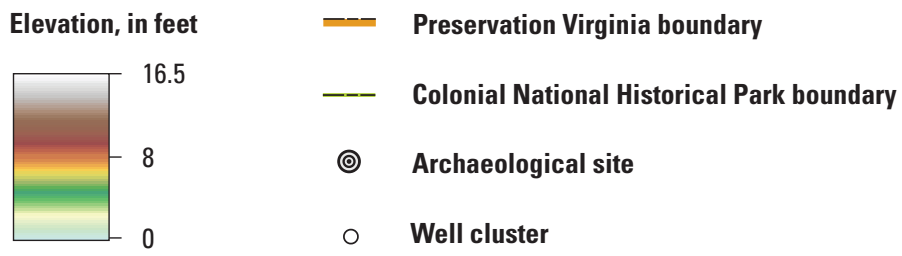

Figure 29. Maps showing the land-surface altitude and areas inundated when the water-surface altitude from high tides or storm surges reaches $A, 1.5 \mathrm{feet}(\mathrm{ft}), B, 2.0 \mathrm{ft}, C, 2.5 \mathrm{ft}, D, 3.0 \mathrm{ft}$, and $E, 5.0 \mathrm{ft}$ above North American Vertical Datum of 1988 on Jamestown Island, Colonial National Historical Park, Virginia.-Continued 


\section{Summary}

With archaeological and cultural sites dating from the Paleoindian period (15,000 to 8,000 years ago) to the present, Jamestown Island, Colonial National Historical Park (COLO), Virginia, is best known as the site of the first permanent English settlement in North America in 1607 (figs. 1, 2). The island is located on the lower James River near the mouth of Chesapeake Bay and the Atlantic Ocean with a low landsurface altitude (two-thirds of the island is less than $5 \mathrm{ft}$ above NAVD 88). The island contains a rich archaeological record that can reveal important aspects of our Nation's early history; it is jointly managed by the National Park Service (NPS) and Preservation Virginia, a nonprofit organization that owns 22 acres of the 1,500-acre island. The island and its archaeological, cultural, and ecological resources and infrastructure are threatened by sea-level rise, which prompted the NPS to identify COLO as one of 25 parks most threatened by climate change. The rate of rise in the area is more than 2.5 times the global average. This higher rate is caused by melting of landbased ice and thermal expansion of seawater, a decrease in the rate of northward flow in the Gulf Stream, and land subsidence from glacial isostatic adjustment and large groundwater withdrawals.

Although the effects of sea-level rise typically are considered surface-water phenomena, sea-level rise also can damage resources by changing groundwater hydrology and chemistry. Knowledge of these effects is essential to developing effective management strategies. Consequently, the U.S. Geological Survey (USGS) in cooperation with the NPS began a study in 2015 as a part of the USGS/NPS Water-Quality Partnership to develop a long-term, groundwater-monitoring program and assess the initial data to support the development of a management strategy and subsequent updates. This report describes the monitoring program, results of the monitoring, interpretation of the results, and their management implications.

The monitoring network includes 45 wells and piezometers in 2 individual clusters and 3 transects of individual and clustered wells and piezometers. Transects represent low- and high-altitude upland sites that extend from the uplands into adjacent lowland marshes. The differences in the altitude of the uplands creates two different hydrologic and chemical settings. Groundwater levels, dissolved-oxygen concentrations, specific conductance, and $\mathrm{pH}$ of groundwater and James River water were measured at various frequencies. Specific conductance was used as a surrogate for salinity of the water.

At Jamestown Island, surface-water/groundwater exchange means that groundwater in the Surficial aquifer responds to both surface-water and groundwater processes. The main surface-water processes are discharge from the James River watershed to the west and flow of saline water from Chesapeake Bay and the Atlantic Ocean to the east. The flow of saline water is affected by semidiurnal tides and storms surges. High surface-water discharge reduces salinity in the river by pushing saline water seaward. Salinity in the river increases as discharge decreases, allowing the density of the saline water and tides to push the saline water upstream. Storm surges can cause large but brief increases in salinity, whereas changes in the semidiurnal tides and sea-level rise cause small, slower changes in salinity.

The Surficial aquifer is the main aquifer affecting groundwater hydrology and chemistry on Jamestown Island. Groundwater hydrology and chemistry are largely controlled by land-surface altitude and slope, differences in lateral and vertical sediment characteristics, distance from surface waters, and the degree of hydraulic connectivity between the surfacewater channels and aquifer sediment. The Surficial aquifer has three water sources that are affected partly by land-surface altitude - recharge from land surface by precipitation across the island, recharge by saline water that inundates the land surface during high tides and storm surges, and lateral flow of saline water through the aquifer from adjacent surface waters. Marshes typically are inundated during high tides and storm surges. Low upland ridges can be inundated by storm surges, whereas high upland ridges have not been inundated recently, even by large storm surges.

The depth that stream valleys and channels incise into aquifer sediment affects the hydraulic connectivity between the surface waters and Surficial aquifer, as this connectivity is predominately influenced by stage in the surface-water channels, and the permeability of subsurface materials surrounding these channels. Stream valleys are incised to various depths and cut only into the upper clayey sediment or into the deeper, coarse-grained sand of the Surficial aquifer (Johnson and Hobbs, 2001). The valleys were subsequently filled with low-permeability organic sand and mud. Current surface-water channels can incise only into the valley fill or through the fill and connect directly to permeable parts of the aquifer. Where surface-water channels incise only into low-permeability sediment, responses to changes in surface-water salinity and levels are attenuated. Where channels incise into coarse-grained aquifer sediment, the change in groundwater specific conductance as a result of changes in surface-water salinity can be rapid.

The hydrologic and chemical settings of groundwater can be characterized primarily by the altitude of the uplands. Highaltitude upland settings are represented by the Island House, and low-altitude upland settings are represented by Black Point. Both settings have adjacent marshes. Horizontal waterlevel altitudes and gradients varied by setting. Beneath the Island House, the depth to groundwater in the coarse-grained sand depended on land-surface altitude; the altitude of the water table typically differed by $0.1 \mathrm{ft}$ or less among all sites throughout the study. Although the expected horizontal gradient was from the uplands to the marsh, the highest groundwater level most commonly was at the marsh/upland edge so that the gradient and resulting flow was from that point toward the upland and the marsh. Beneath Black Point, the gradient in the coarse-grained sand varied from the upland to both marshes, from both marshes toward the upland, and from the southern marsh through the upland to the northern marsh. 
The specific conductance of groundwater beneath marshes responded differently to changes in river salinity because of differences in controls on the processes. At sites with good hydraulic connection to surface waters, the specific conductance of groundwater in the coarse-grained sand responded rapidly to changing specific conductance of surface waters, whereas response in groundwater in the fine-grained sand was attenuated. Effects were attenuated in all aquifer sediment where the site did not appear to be hydraulically connected to surface water or the sediment was not deeply incised by the surface-water channel.

The specific conductance (generally less than $200 \mu \mathrm{S} /$ $\mathrm{cm}$ ) and $\mathrm{pH}$ (greater than 5.0 standard units) of groundwater beneath much of the uplands at the Island House are typical of groundwater in noncarbonate sedimentary aquifers recharged by precipitation. Upland sites near the marsh reflected the effects of changing salinity in the river more than marsh sites.

Conditions in groundwater beneath the uplands at Black Point were different from those at the Island House. The specific conductance ranged from 2,500 to $15,400 \mu \mathrm{S} / \mathrm{cm}$ and decreased with depth, indicating a density inversion; water with the greatest salinity and density was at the water table. The vertical salinity distribution apparently was controlled by sources of saline water and sediment permeability rather than density. Such a density inversion was present in groundwater beneath several marsh sites and other low-altitude, uplandridge sites. The $\mathrm{pH}$ of groundwater was less than 3.5 at the three depths at this site at the start of the study and generally increased during the study.

The presence of acidic, saline water at the water table poses an immediate threat to archaeological resources. The original concern was that the deterioration of resources would accelerate from wetting and drying as the water table rose to within 1-2 ft of land surface. Because the fine roots of most plants are less than $1 \mathrm{ft}$ below land surface, these roots can cause acidic, saline groundwater to be drawn through unsaturated sediment by hydraulic redistribution. Such acidic, saline water will accelerate the deterioration of artifacts, even if the water table remains several feet below land surface. These conditions also may contribute to the mortality of deciduous trees along the ridge at Black Point. Confirmation of the relevant processes and identification of areas at significant risk would likely result from continued groundwater monitoring, development of a protocol for testing soil salinity, soil moisture, and $\mathrm{pH}$, and identification of sediment containing pyrite.

\section{References Cited}

Armstrong, W., Brändle, W., and Jackson, M.B., 1994, Mechanisms of flood tolerance in plants: Acta Botanica Netherland, v. 43, no. 4, p. 307-358, accessed August 2021 at https://doi.org/10.1111/j.1438-8677.1994.tb00756.x.

Blanton, D.B., Kandle, P., and Downing, C.M., 2000, Archaeological survey of Jamestown Island, Jamestown archaeological assessment, 1992-1996-Colonial National Historical Park: National Park Service, 398 p.

Craft, C.B., Seneca, E.D., and Broome, S.W., 1991, Porewater chemistry of natural and created marsh soils: Journal of Experimental Marine Biology and Ecology, v. 152, no. 2, p. 187-200, accessed August 2021 at https://doi. org/10.1016/0022-0981(91)90214-H.

Cramer, J., Rickles, E., and Gatz-Miller, H., 2019, Subsurface hydrologic processes-An unseen, ongoing threat to archaeological sites on Jamestown Island [abs.]: 49th Annual Middle Atlantic Archaeological Conference, Ocean City, Md., March 21-24, 2019.

Dawson, T.E., 1992, Hydraulic lift and water use by plantsImplications for water balance, performance, and plantplant interactions: Ecología (Madrid), v. 95, p. 565-574.

Eggleston, J., and Pope, J.P., 2013, Land subsidence and relative sea level rise in the southern Chesapeake Bay region: U.S. Geological Survey Circular 1392, 30 p., accessed August 2021 at https://doi.org/10.3133/cir1392.

Egloff, K., and Woodward, D., 2006, First people-The early Indians of Virginia: Charlottesville, Va., University of Virginia Press, $112 \mathrm{p}$.

Ezer, T., and Atkinson, L.P., 2015, Sea level rise in VirginiaCauses, effects, and response: Virginia Journal of Science, v. 66, no. 3, p. 355-369, accessed August 2021 at https:// digitalcommons.odu.edu/vjs/vol66/iss3/8.

Freeze, R.A., and Cherry, J.A., 1979, Groundwater: Englewood Cliffs, N.J., Prentice Hall, 582 p.

Holdahl, S.R., and Morrison, N.L., 1974, Regional investigations of vertical crustal movements in the U.S., using precise relevelings and mareograph data: Tectonophysics, v. 23, no. 4, p. 373-390, accessed August 2021 at https:// doi.org/10.1016/0040-1951(74)90073-0.

Johnson, G.H., 2007, Geology of the lower James-York Peninsula and Jamestown Island, in Bailey, C.M., and Lamoreaux, M.H., eds., Geology of Jamestown and the lower James River basin: 37th Annual Virginia Geological Field Conference, October 12-14, 2007, p. 1-28. 
Johnson, G.H., and Hobbs, C.H., III, 2001, The geology of Jamestown Island, Virginia, in Brown, M.R., III, and Carson, C., Geological development and environmental reconstruction of Jamestown Island, Jamestown archaeological assessment, 1992-1996: Report for Colonial National Historical Park, National Park Service, 192 p.

Krieger, R.A., Hatchett, J.L., and Poole, J.L., 1957, Preliminary survey of the saline-water resources of the United States: U.S. Geological Survey Water-Supply Paper 1347, $171 \mathrm{p}$.

Ladd, D.E., 2020, Field parameters and water levels from monitoring sites at Jamestown Island, Virginia, 20162018: U.S. Geological Survey data release, https://doi. org/10.5066/P9K7X61F.

Lord, C.J., III, and Church, T.M., 1983, The geochemistry of salt marshes - Sedimentary ion diffusion, sulfate reduction, and pyritization: Geochimica et Cosmochimica Acta, v. 47, no. 8, p. 1381-1391, accessed August 2021 at https://doi. org/10.1016/0016-7037(83)90296-X.

Masterson, J.P., Fienen, M.N., Thieler, E.R., Gesch, D.B., Gutierrez, B.T., and Plant, N.G., 2013, Effects of sealevel rise on barrier island groundwater system dynamics - ecohydrological implications: Ecohydrology, v. 7, no. 3, p. 1064-1071, accessed August 2021 at https://doi. org/10.1002/eco.1442.

Masterson, J.P., and Garabedian, S.P., 2007, Effects of sealevel rise on ground water flow in a coastal aquifer system: Ground Water, v. 45, no. 2, p. 209-217, accessed August 2021 at https://doi.org/10.1111/j.1745-6584.2006.00279.x.

McFarland, E.R., and Bruce, T.S., 2006, The Virginia Coastal Plain hydrogeologic framework: U.S. Geological Survey Professional Paper 1731, 118 p., 25 plates.

Mitsch, W.J., and Gosselink, J.G., 2007, Wetlands (4th ed.): Hobokon, N.J., John Wiley and Sons, Inc., 722 p.

Moyer, D.L., Anderholm, S.K., Hogan, J.F., Phillips, F.M., Hibbs, B.J., Witcher, J.C., Matherne, A.M., and Falk, S.H., 2013, Knowledge and understanding of dissolved solids in the Rio Grande-San Acacia, New Mexico, to Fort Quitman, Texas, and plan for future studies and monitoring: U.S. Geological Survey Open-File Report 2013-1190, 55 p., accessed August 2021 at https://doi.org/10.3133/ ofr20131190.

National Oceanic and Atmospheric Administration [2018], Data tools - 1981-2010 normals: National Centers for Environmental Information web page, accessed March 28, 2018, at https://www.ncdc.noaa.gov/cdo-web/datatools/normals.
National Oceanic and Atmospheric Administration, 2020, Lidar data: National Oceanic and Atmospheric Administration web page, Digital Coast Data Access Viewer, accessed August 31, 2020, at https://coast.noaa.gov/dataviewer.

National Park Service, 2001, Jamestown archeological assessment - Colonial National Historical Park, Yorktown, Virginia: National Park Service report, $140 \mathrm{p}$.

Powell, S.W., and Day, F.P., Jr., 1991, Root production in four communities in the Great Dismal Swamp: American Journal of Botany, v. 78, no. 2, p. 288-297, accessed August 2021 at https://doi.org/10.1002/j.1537-2197.1991.tb15755.x.

Prieto, I., Armas, C., and Pugnaire, F.I., 2012, Water release through plant roots - New insights into it and consequences at the plant and ecosystem level: The New Phytologist, v. 193, no. 4, p. 830-841, accessed August 2021 at https:// doi.org/10.1111/j.1469-8137.2011.04039.x.

Rahmstorf, S., 2010, A new view on sea level rise: Nature Climate Change, v. 1, no. 1004, p. 44-45, accessed August 2021 at https://doi.org/10.1038/climate.2010.29.

Ricci, G., Robadue, D.D., Jr., Rubinoff, P., Casey, A., and Babson, A.L., 2019, Integrated coastal climate change vulnerability assessment Colonial National Historical Park: Natural Resources Report NPS/COLO/NRR--2019/1945, 308 p.

Rice, K.C., Hong, B., and Shen, J., 2012, Assessment of salinity intrusion in the James and Chickahominy Rivers as a result of simulated sea-level rise in Chesapeake Bay, East Coast, USA: Journal of Environmental Management, v. 111, p. 61-69, accessed August 2021 at https://doi.org/10.1016/j. jenvman.2012.06.036.

Sánchez-Pérez, J.M., Lucot, E., Bariac, T., and Trémolières, M., 2008, Water uptake by trees in a riparian hardwood forest (Rhine floodplain, France): Hydrological Processes, v. 22, no. 3, p. 366-375, accessed August 2021 at https:// doi.org/10.1002/hyp.6604.

Saunders, S., Easly, T., Farver, S., Logan, J.A., and Spencer, T., 2009, National Parks in peril-The threats of climate disruption: Louisville, Co., The Rocky Mountain Climate Organization, $56 \mathrm{p}$.

Speiran, G.K., 1996, Geohydrology and geochemistry near coastal ground-water-discharge areas of the Eastern Shore, Virginia: U.S. Geological Survey Water-Supply Paper 2479, $73 \mathrm{p}$.

Speiran, G.K., 2010, Effects of groundwater-flow paths on nitrate concentrations across two riparian forest corridors: Journal of the American Water Resources Association, v. 46, no. 2, p. 246-260, accessed August 2021 at https://doi. org/10.1111/j.1752-1688.2010.00427.x. 
Speiran, G.K., and Wurster, F.C., 2021, Hydrology and water quality of the Great Dismal Swamp, Virginia and North Carolina, and implications for hydrologic-management goals and strategies: U.S. Geological Survey Scientific Investigations Report 2020-5100, 104 p. [Also available at https://doi.org/10.3133/sir20205100.]

Thornberry-Ehrlich, T.L., 2016, Colonial National Historical Park - Geologic resources inventory report: Natural Resource Report NPS/NRSS/GRD/NRR-2016/1237, 84 p.

Trewartha, G.T., and Horn, L.H., 1980, An introduction to climate (5th ed.): New York, N.Y., McGraw-Hill, 416 p.

University of Virginia, 2000, Virginia potential evapotranspiration, annual precipitation, and annual precipitation minus potential evapotranspiration: University of Virginia Climatology Office web page, accessed March 28, 2018, at http:// climate.virginia.edu/va_pet_prec_diff.htm.

U.S. Geological Survey, 1983, Surry Quadrangle, Virginia: U.S. Geological Survey Topographic Map 7.5-minute series, 1 sheet.

U.S. Geological Survey, 1984, Hog Island Quadrangle, Virginia: U.S. Geological Survey Topographic Map 7.5-minute series, 1 sheet.

U.S. Geological Survey, 2012, The national field manual for the collection of water-quality data (ver. 7): U.S. Geological Survey Techniques and Method, book 9, chaps. A1-A9, accessed April 5, 2016, at https://www.usgs.gov/ mission-areas/water-resources/science/national-fieldmanual-collection-water-quality-data-nfm?qt-science_center_objects $=0 \#$ qt-science_center_objects.

U.S. Geological Survey [2021], USGS 02042770 James River at Jamestown Ferry Pier, VA, in USGS water data for the Nation: U.S. Geological Survey National Water Information System database, accessed August 2021 at https://doi.org/10.5066/F7P55KJN. [Site information directly accessible at https://waterdata.usgs. gov/va/nwis/uv/?site_no $=02042770 \&$ PARAmeter $\mathrm{cd}=00065,00060,62620,62614$.]

White, W.N., 1932, A method of estimating ground-water supplies based on discharge by plants and evaporation from soil-Results of investigations in Escalante Valley, Utah: U.S. Geological Survey Water-Supply Paper 659A, 105 p. 
For more information, contact

Center Director, Virginia and West Virginia Water Science Center U.S. Geological Survey

1730 East Parham Road

Richmond, VA 23228

Or visit our website at: https://www.usgs.gov/centers/va-wv-water

Publishing support provided by the

West Trenton Publishing Service Center. 
